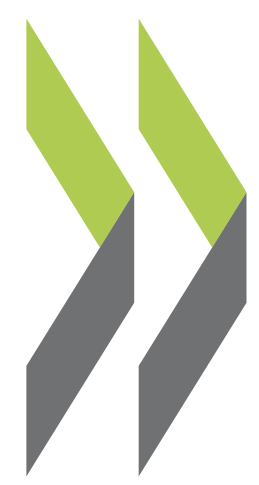

OECD Science, Technology and Industry Working Papers $2003 / 13$

\title{
An Overview \\ of Biotechnology Statistics in Selected Countries
}

Andrew Devlin 
Organisation de Coopération et de Développement Economiques

Organisation for Economic Co-operation and Development

26-Nov-2003

DIRECTORATE FOR SCIENCE, TECHNOLOGY AND INDUSTRY

English text only

AN OVERVIEW OF BIOTECHNOLOGY STATISTICS IN SELECTED COUNTRIES (STI WORKING PAPER 2003/13)

Statistical Analysis of Science, Technology and Industry

Andrew Devlin 


\section{STI Working Paper Series}

The Working Paper series of the OECD Directorate for Science, Technology and Industry is designed to make available to a wider readership selected studies prepared by staff in the Directorate or by outside consultants working on OECD projects. The papers included in the series cover a broad range of issues, of both a technical and policy-analytical nature, in the areas of work of the DSTI. The Working Papers are generally available only in their original language - English or French - with a summary in the other.

Comment on the papers is invited, and should be sent to the Directorate for Science, Technology and Industry, OECD, 2 rue André-Pascal, 75775 Paris Cedex 16, France.

The opinions expressed in these papers are the sole responsibility of the author(s) and do not necessarily reflect those of the OECD or of the governments of its member countries.

\section{http://www.oecd.org/sti/working-papers}


DSTI/DOC(2003)13

\title{
AN OVERVIEW OF BIOTECHNOLOGY STATISTICS IN SELECTED COUNTRIES
}

\author{
Andrew Devlin \\ Economic Analysis and Statistics Division, OECD
}

\begin{abstract}
This report provides an update of the current state of the biotechnology industry based on primarily official statistical sources. As biotechnology becomes increasingly viewed as a strategic sector, the need for reliable biotechnology statistics from which informed policy decisions can be made grows. This report addresses that need by compiling statistics on biotechnology both on a country-by-country basis and to a limited degree across countries. Also included is a brief overview of some of the important biotechnology policies where the information is publicly available.

This work has benefited from the OECD working with member countries and observer countries to develop methodological tools for measuring biotechnology. While some of this work is provisional, will change as experience in the field is gained and should not be viewed as the definitive reference, the data contained in this report represents a significant step forward from only a few years ago when only a few OECD member countries had any official statistics describing biotechnology.
\end{abstract}




\title{
PANORAMA DES STATISTIQUES DES BIOTECHNOLOGIES DANS QUELQUES PAYS CHOISIS
}

\author{
Andrew Devlin \\ Division des analyses économiques et des statistiques
}

\begin{abstract}
Résumé
Le présent rapport fait le point sur l'état actuel du secteur des biotechnologies en se fondant principalement sur des sources statistiques officielles. L'émergence des biotechnologies comme secteur stratégique renforce le besoin de disposer de statistiques fiables susceptibles d'éclairer les choix publics dans ce domaine. C'est dans cette optique que sont réunies dans ce rapport des statistiques nationales relatives à ce secteur et, bien que moins nombreuses, des comparaisons internationales. Y sont en outre présentées quelques-unes des principales politiques biotechnologiques pour lesquelles l'information est accessible librement.

Ce travail a pu être réalisé grâce aux activités de développement d'outils méthodologiques de mesure des biotechnologies menées par l'OCDE en collaboration avec les pays membres et les pays observateurs. Bien qu'une partie des travaux présentés soit provisoire, appelée à évoluer à mesure que s'accumuleront les expériences dans ce domaine et, par conséquent, ne doive pas être considérée comme une référence définitive, il n'en demeure pas moins que les données contenues dans ce rapport représentent un progrès sensible, puisqu'il y a quelques années encore, une poignée de pays de l'OCDE seulement disposait de statistiques décrivant les biotechnologies.
\end{abstract}




\section{TABLE OF CONTENTS}

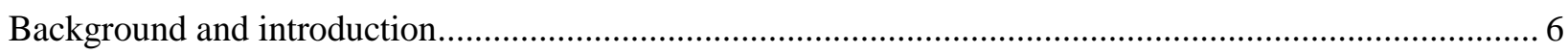

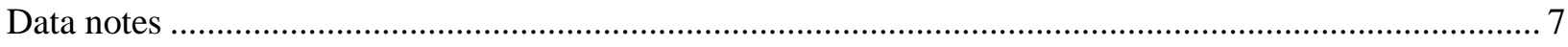

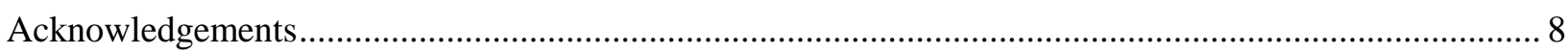

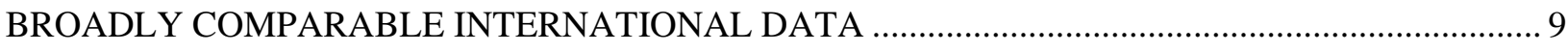

BIOTECHNOLOGY PUBLIC RESEARCH AND FUNDING …................................................ 10

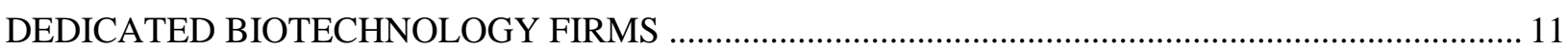

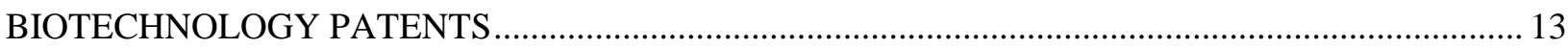

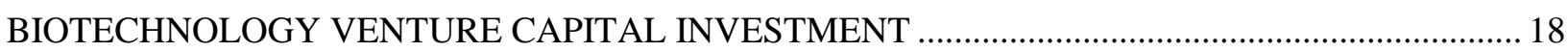

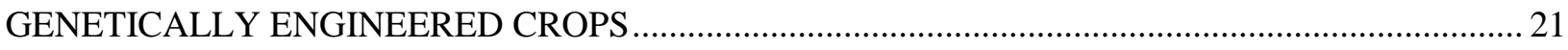

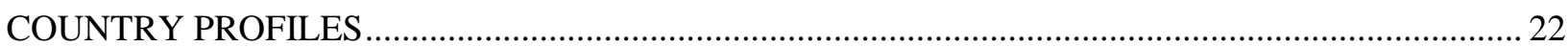

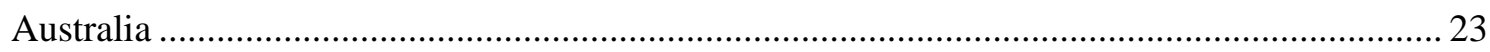

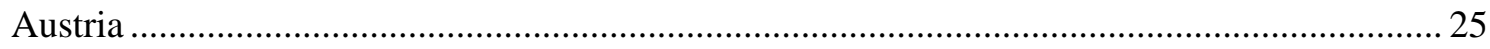

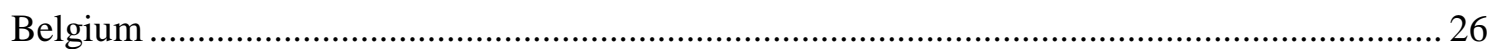

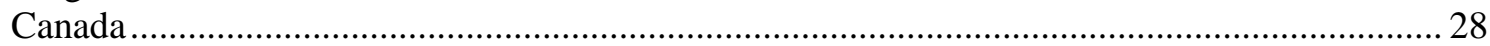

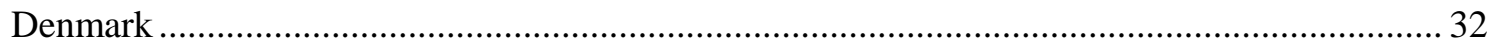

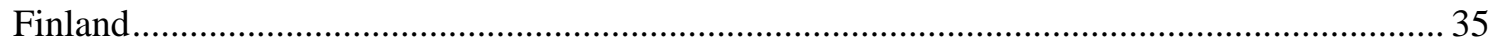

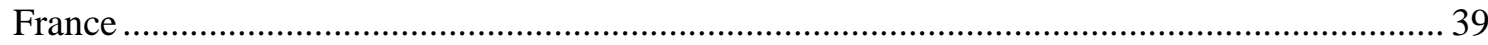

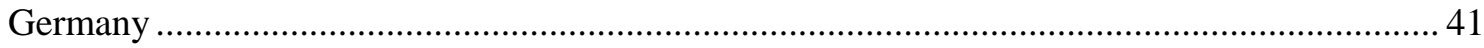

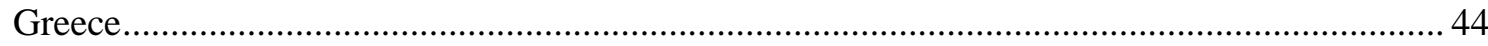

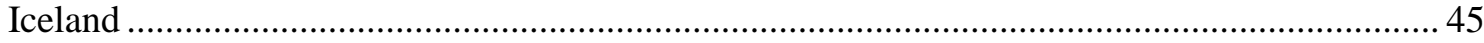

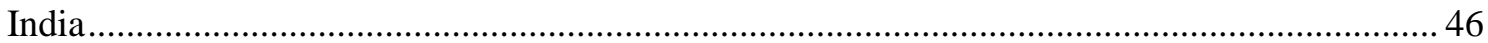

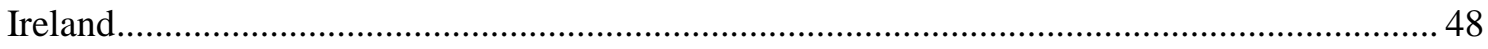

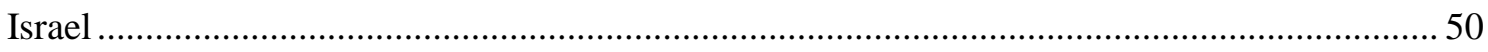

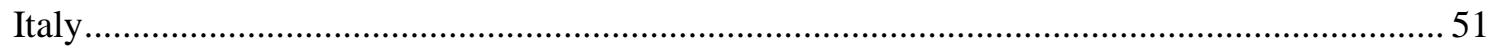

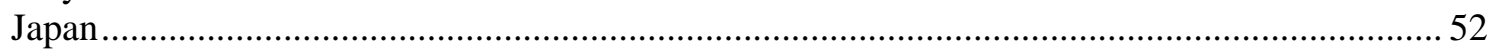

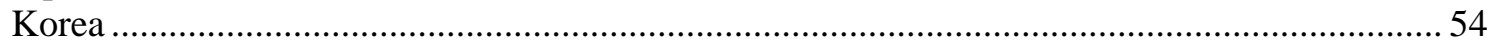

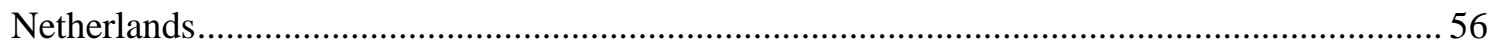

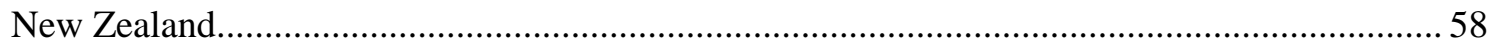

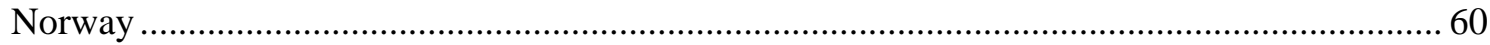

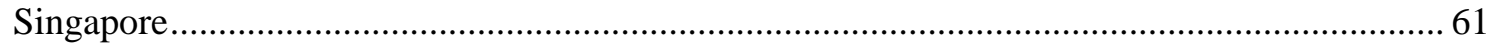

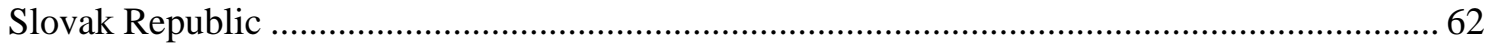

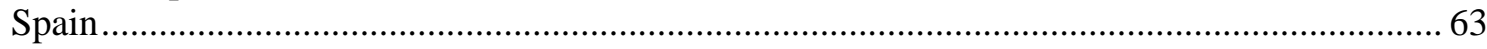

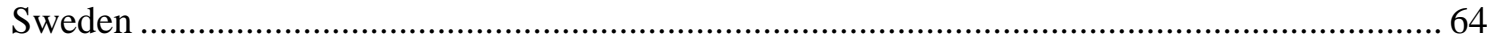

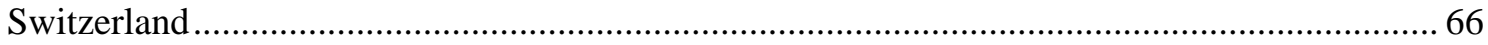

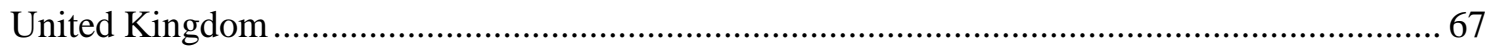

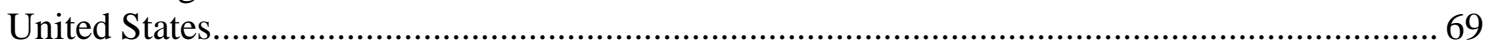

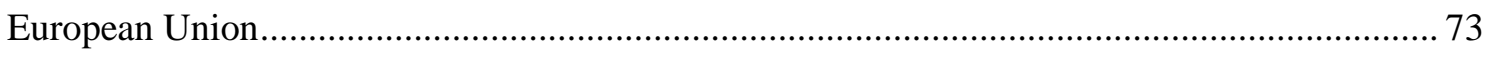

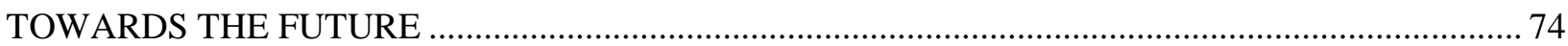




\section{Background and introduction}

This document reflects recent efforts by the OECD Secretariat to obtain an accurate assessment of the current state of biotechnology statistics in OECD member and selected observer countries, based mainly on official statistics.

The first compendium of biotechnology statistics released in 2001 was well received and used by a wide variety of people, but was based on diverse sources, mainly from private unofficial providers (van Beuzekom, 2001 ${ }^{1}$ ). This second edition is based to a much larger degree than the first version on official data and is in response to much demand for an updated version of the last compendium, and so includes new data that have become available since the first edition of the biotechnology statistics compendium. It is hoped that this edition will also receive wide coverage and use.

Annual ad hoc meetings of National Experts on Science and Technology Indicators (NESTI) experts in biotechnology statistics started in March 2000. National experts from OECD countries and observer countries have worked together to agree on a statistical definition of biotechnology statistics (see box below). This statistical definition has been refined at each annual meeting subsequent to the statistical definition first agreed to in 2001.

After agreeing to a statistical definition, the next logical step is to collect data using this statistical definition. In 2002 national experts agreed to recommend the addition of an optional question in the national R\&D surveys. This question asked respondents to identify whether they performed any biotechnology R\&D. Biotechnology R\&D results from this optional question are still in the preliminary phase. It is expected that data will slowly become available over time as more countries add the question to their R\&D surveys.

In 2003 a model survey on biotechnology use and development was presented to delegates at the annual meeting. Countries have been encouraged to collect biotechnology statistics using the agreed statistical definition and in 2003 have been encouraged to collect a variety of biotechnology statistics using the model use and development survey. As these developments are recent, available biotechnology statistics are generally still not harmonised and vary considerably across countries. Therefore international comparisons should be undertaken with extreme care.

Data in this document are presented on a country-by-country basis. In the first section, where it has been possible, the Secretariat has combined information which is broadly comparable into one section.

Biotechnology statistics vary across countries depending on individual country interests in biotechnology. In addition to different areas of interest in indicators across countries there are also differences in the definition of the indicators used (e.g. full-time equivalents or head counts of personnel). Therefore country-specific data are presented for those countries for which data are readily available and are a collection of what is available. These country profiles are by no means exhaustive.

A draft version of this compendium was presented to delegates at the fourth ad hoc NESTI meeting on biotechnology statistics in May 2003. This document has been released as a working paper after taking into consideration helpful comments resulting from that meeting.

This compendium should serve as a guide to data available at the time of production and not a definitive reference. The OECD Secretariat also hopes that this compendium will lead to a continued improvement in the collection and reporting of international biotechnology statistics.

1. van Beuzekom, Brigitte (2001), "Biotechnology Statistics in OECD Member Countries: Compendium of Existing National Statistics”, STI Working Paper 2001/6, OECD, Paris. 


\section{Box 1. OECD statistical definition of biotechnology}

The fourth annual meeting of experts from OECD member and observer countries in 2003 resulted in the agreement on the following statistical definition of biotechnology.

The provisional single definition of biotechnology is as follows: "The application of Science \& Technology to living organisms as well as parts, products and models thereof, to alter living or non-living materials for the production of knowledge, goods and services".

The (indicative, not exhaustive) list of biotechnologies as an interpretative guideline to this single definition is:

- DNA (the coding): genomics, pharmaco-genetics, gene probes, DNA sequencing/synthesis/amplification, genetic engineering.

- Proteins and molecules (the functional blocks): protein/peptide sequencing/synthesis, lipid/protein glyco-engineering, proteomics, hormones, and growth factors, cell receptors/signalling/pheromones.

- Cell and tissue culture and engineering: cell/tissue culture, tissue engineering, hybridisation, cellular fusion, vaccine/immune stimulants, embryo manipulation.

- Process biotechnologies: bioreactors, fermentation, bioprocessing, bioleaching, bio-pulping, bio-bleaching, biodesulphurization, bioremediation, and biofiltration.

- Sub-cellular organisms: gene therapy, viral vectors.

- $\quad$ Other (please specify).

\section{Data notes}

Data presented are the most recent available at the time of data collection. Where data have been converted to a common currency they have been converted to USD. Data have been converted according to the exchange rate or PPP rate for the year of the data concerned.

The compendium includes data collected for two main reasons:

- Regulatory or legal. Data collected in this fashion provide complete coverage of a given activity (e.g. patent data).

- Official government. Official government statistics have been obtained by surveys (e.g. the Canadian R\&D survey).

Data sources are listed at the end of each country profile. For more information on the data, readers are referred to the publications or Web address given at the end of the relevant section. 


\section{Acknowledgements}

The Secretariat would like to thank the Government of Canada for providing a generous voluntary contribution in support of this working paper, which was prepared by Andrew Devlin of the OECD Directorate for Science, Technology and Industry (STI). Invaluable editorial comments and advice were received from Andrew Wyckoff, Dirk Pilat, Sheridan Roberts (STI/EAS) and Iain Gillespie (STI/BIO). However none of this information would be available were it not for the data and assistance kindly supplied from statisticians in the member and observer countries covered in this report. 
DSTI/DOC(2003)13

BROADLY COMPARABLE INTERNATIONAL DATA

\section{Box 2. International comparisons}

This section contains broadly comparable data. Some data are more easily compared (e.g. patents) as they are collected according to well defined guidelines. Other data (e.g. publicly funded R\&D funding) suffer from differences in definitions across countries, meaning that comparative analysis should be conducted with caution. 


\title{
BIOTECHNOLOGY PUBLIC RESEARCH AND FUNDING
}

\begin{abstract}
Although the field of biotechnology has grown markedly owing to scientific advances in areas such as genomics and genetic engineering, comparable international data remain scarce. In particular it is not possible to include the Untied States and Japan, countries which invest quite heavily in biotechnology R\&D due to the information not being publicly available. Available data indicate that publicly funded biotechnology R\&D varies considerably across OECD countries. In Denmark, Canada and New Zealand, biotechnology has shares above $10 \%$.
\end{abstract}

Figure 1. Publicly funded biotechnology R\&D as a percentage of publicly funded R\&D, 2000 or nearest available year

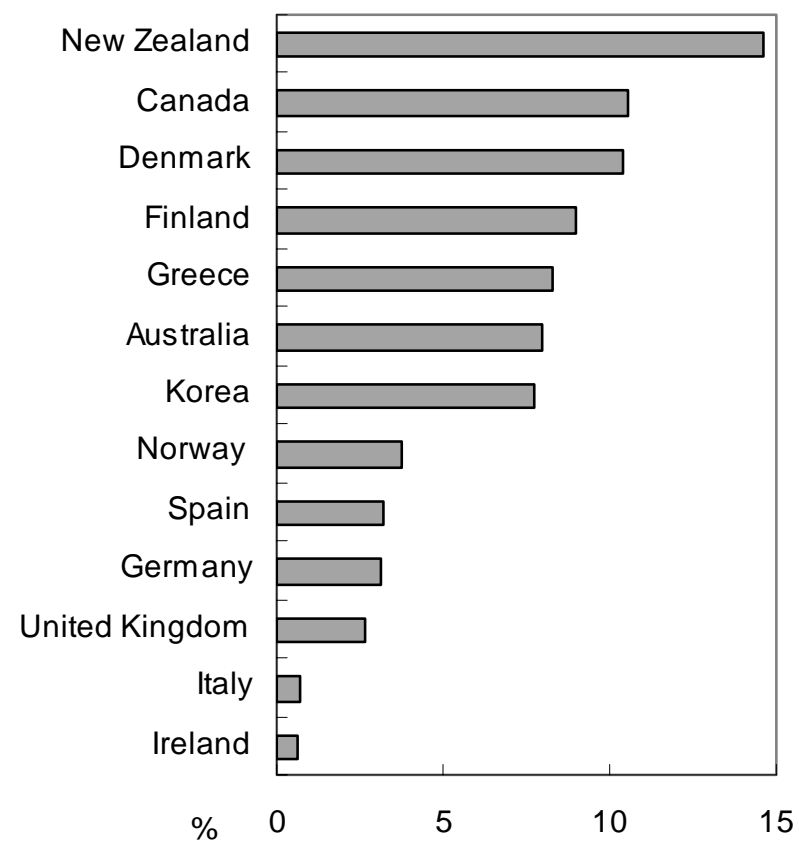

Notes: R\&D definitions vary across countries - especially with respect to inclusion or exclusion of biotechnology R\&D performed by the higher education sector. The data are based on: government budgetary appropriations or outlays for R\&D (GBAORD) for Australia, Canada, Germany, Greece, Ireland, Italy, Korea, Spain and the United Kingdom; government-financed gross domestic expenditure on R\&D (GERD) for Norway; and the sum of R\&D performed by government, higher education and private non-profit sectors for Denmark, Finland and New Zealand.

Sources: Eurostat and national sources, May 2003. 


\section{DEDICATED BIOTECHNOLOGY FIRMS}

The number of dedicated biotechnology firms ${ }^{2}$ (DBFs) per million inhabitants is highest in Sweden, Switzerland and Canada. If a wider definition is considered then there are a high number of biotechnology firms in New Zealand, as 47 firms per million inhabitants identified at least one biotechnology process.

The order of countries is relatively unaffected when considering the ratio of dedicated biotechnology firms to millions of GDP (expressed in USD PPPs). However, dedicated biotechnology firm ratios do not take into consideration the size of the firms involved.

Over half of dedicated biotechnology firms in the University of Siena study were involved in cell and tissue culture and engineering, DNA or proteins and molecules. These three areas accounted for 55\% of areas in which dedicated biotechnology firms were involved.

Figure 2. Dedicated biotechnology firms per million inhabitants, 2000

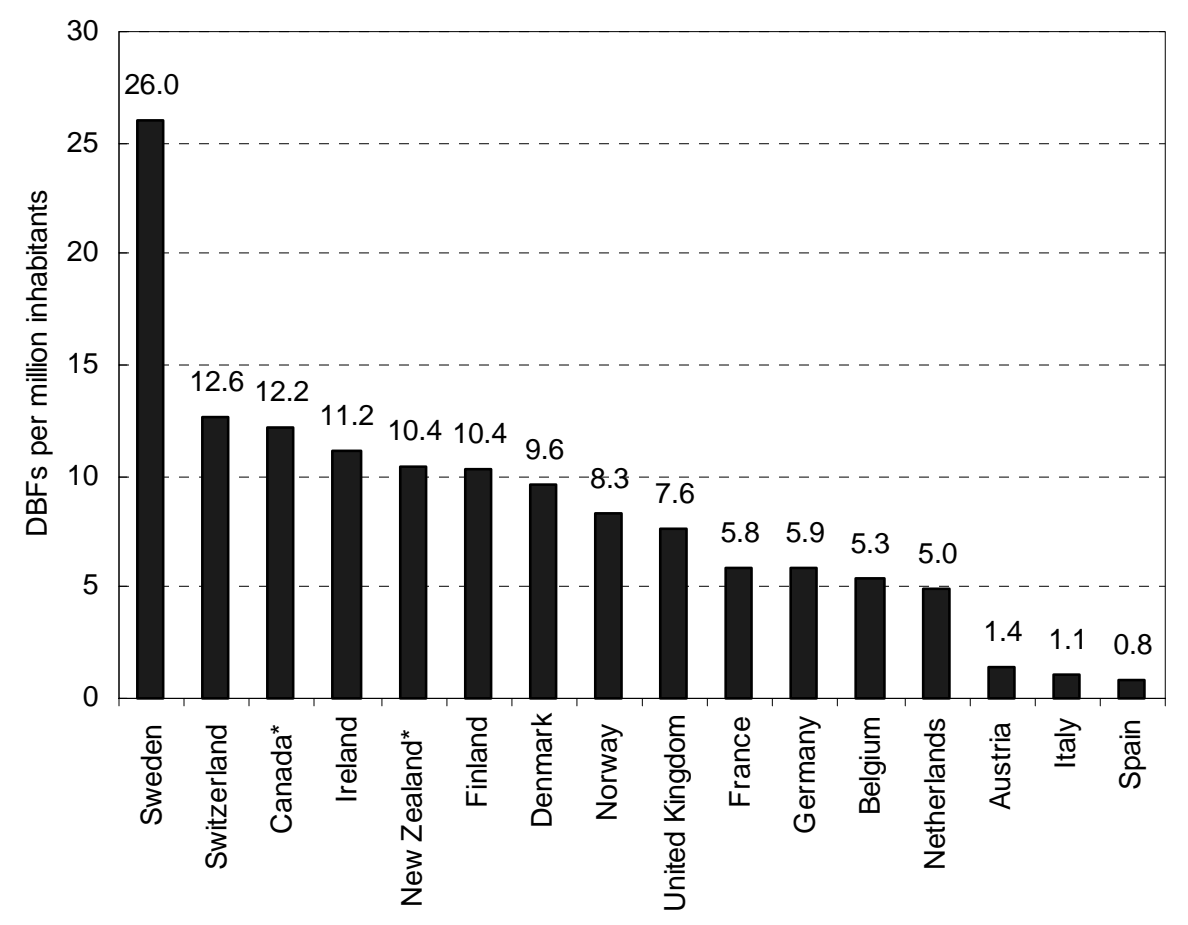

Notes: New Zealand reports data for 1998-99 for firms identifying at least one biotechnology process. All other country data are for December 2000. Biotechnology definitions have not been harmonised across countries so some differences may be due to definitional differences.

Source: Biotechnology Industry database, University of Siena, Statistics Canada, Statistics New Zealand. *The University of Siena is the source for all countries except for Canada and New Zealand.

2. Dedicated biotechnology firms are defined as "core biotechnology firms". These firms specialise in biotechnology products and process development, or are specialised suppliers ("Innovation and Competitiveness in European Biotechnology", European Commission 2002.) 
Figure 3. Dedicated biotechnology firms per million GDP USD PPP, 2000

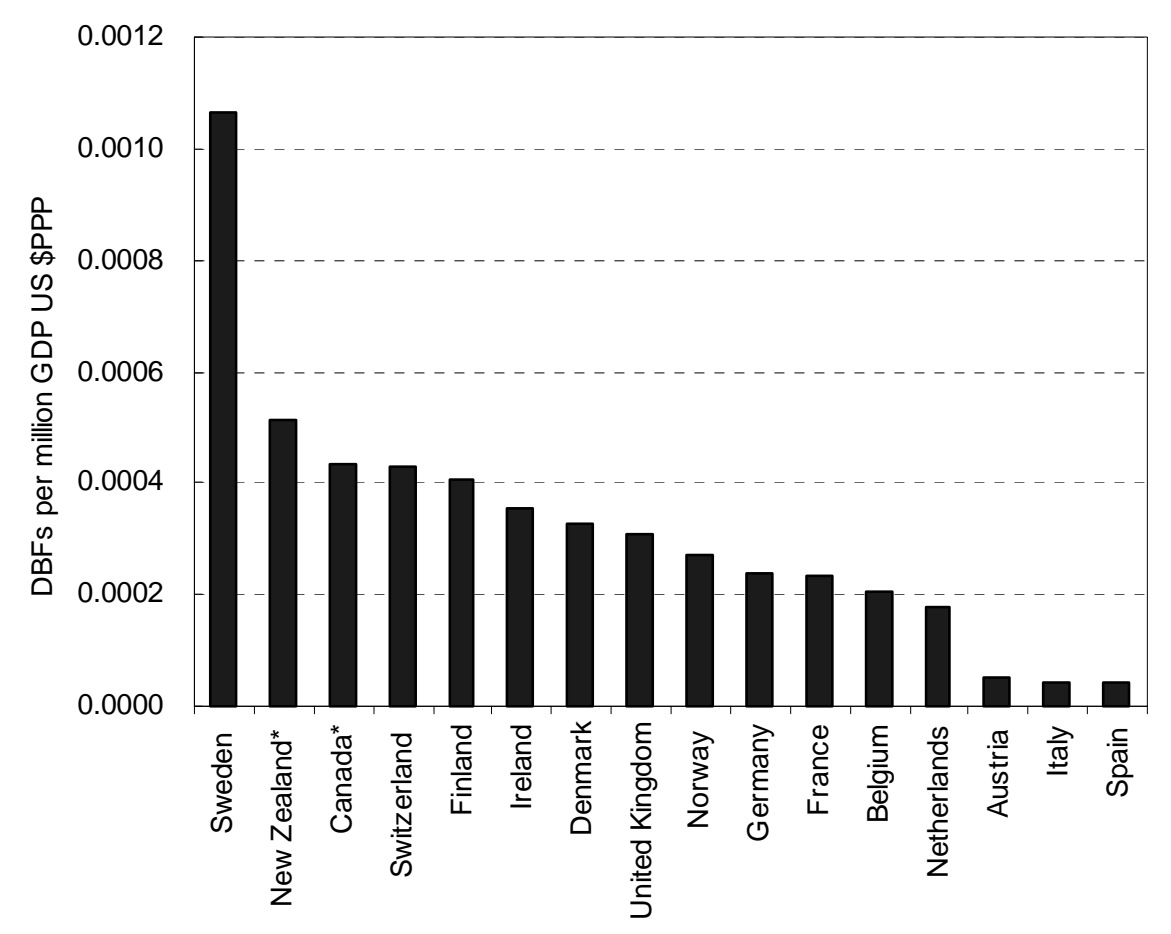

Notes: New Zealand reports data for $1998 / 99$ for firms which identified at least one biotechnology process. Canada reports data for 2001. All other country data are for December 2000. Biotechnology definitions have not been harmonised across all countries, so some differences may be due to definitional differences.

Sources: Biotechnology Industry Database, University of Siena, Statistics Canada, Statistics New Zealand. *The source is University of Siena for all countries except for Canada and New Zealand.

Table 1. Country shares of dedicated biotechnology firms by technological fields

\begin{tabular}{|c|c|c|c|c|c|c|c|c|}
\hline & France & Germany & Italy & Sweden & Switzerland & $\begin{array}{c}\text { United } \\
\text { Kingdom }\end{array}$ & EU 15 & Other \\
\hline $\begin{array}{l}\text { Cell and tissue culture and } \\
\text { engineering }\end{array}$ & 16.9 & 14.0 & 21.2 & 26.3 & 22.3 & 22.9 & 18.7 & 21.1 \\
\hline Sub-cellular organisms & 8.5 & 9.0 & 14.2 & 3.9 & 4.5 & 5.9 & 8.1 & 5.3 \\
\hline DNA & 17.6 & 17.2 & 11.5 & 11.2 & 9.8 & 11.7 & 15.0 & 17.1 \\
\hline Proteins and molecules & 22.1 & 25.6 & 15.9 & 13.4 & 15.2 & 17.0 & 21.6 & 25.0 \\
\hline Process biotechnology & 12.6 & 5.7 & 14.2 & 7.8 & 9.8 & 10.4 & 9.4 & 10.5 \\
\hline Chemical synthesis & 7.4 & 9.4 & 7.1 & 11.2 & 3.6 & 6.7 & 7.6 & 5.3 \\
\hline Bioinformatics & 6.2 & 6.6 & 2.7 & 6.7 & 6.3 & 4.9 & 5.4 & 6.6 \\
\hline Other devices & 5.0 & 7.5 & 12.4 & 10.6 & 24.1 & 17.2 & 10.0 & 6.6 \\
\hline Analysis & 3.7 & 4.8 & 0.9 & 8.9 & 4.5 & 3.3 & 4.2 & 2.6 \\
\hline
\end{tabular}

Note: The column sums for each country may not add to $100 \%$ due to rounding.

The data refer to the numbers of firms and so have not been weighted by size of firm.

Other countries are the Czech Republic, Estonia, Hungary, Iceland, Lithuania, Norway, Poland, Portugal, Romania, Russia and the Slovak Republic.

Source: Biotechnology Industry Database, University of Siena. 
DSTI/DOC(2003)13

\section{BIOTECHNOLOGY PATENTS}

\section{Box 3. Biotechnology patents}

Patents are property rights covering inventions. Patents are especially important for biotechnology firms as many of them have no activity other than R\&D and therefore do not directly exploit their inventions: they sell them, or the right to exploit them, to other firms. A legal property right is therefore needed for the seller to be protected. As patents are intensively used by biotechnology firms, statistics based on patents may reflect with some accuracy certain features of their technological activity.

Patent data reported here cover data collected from two patent offices, the United States Patent and Trademark Office (USPTO) and the European Patent Office (EPO). In the EPO and USPTO databases, country refers to the country of residence of the inventor. For patents with several inventors from different countries, the OECD applies "fractional counting", meaning that the patent is shared between the concerned countries to avoid double counting.

Patents can be compared using different date measures. The priority date corresponds to the first filing worldwide and therefore closest to the invention date: to measure inventive activity a patent should be counted according to the priority date (in the case of patent families, the priority date corresponds to the earliest priority among the set of patents.) Counts by application date introduce a bias owing to a one-year lag between residents and foreigners. The date of grant may provide a more timely series, but reflects administrative delays taken by the patent office to grant the patent, with an average of three years at the USPTO to more than five years at the EPO after the priority application was filed.

The USPTO reports the number of patents granted by priority date. The European Patent Office collects data on patent applications, which may or may not result in a granted patent. The series are presented according to the priority date (the first filing of the invention worldwide - not necessarily at the EPO).

The provisional definition of a biotechnology patent is a patent belonging to one of the International Patent Classification (IPC) codes listed below. This definition is currently under revision.

$\mathrm{A} 01 \mathrm{H} 1 / 00+\mathrm{A} 01 \mathrm{H} 4 / 00+\mathrm{A} 61 \mathrm{~K} 38 / 00+\mathrm{A} 61 \mathrm{~K} 39 / 00+\mathrm{A} 61 \mathrm{~K} 48 / 00+\mathrm{C} 02 \mathrm{~F} 3 / 34+\mathrm{C} 07 \mathrm{G} 11 / 00+\mathrm{C} 07 \mathrm{G} 13 / 00+\mathrm{C} 07 \mathrm{G}$ $15 / 00+$ C07K 4/00 + C07K 14/00 + C07K 16/00 + C07K 17/00 + C07K 19/00 + C12M + C12N + C12P + C12Q + C12S

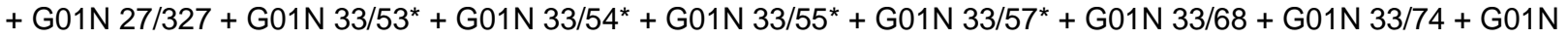
$33 / 76+G 01 N 33 / 78+G 01 N 33 / 88+G 01 N 33 / 92$

For a complete explanation of the IPC codes please consult:

http://www.wipo.int/classifications/fulltext/ipc/ipc6en/indexfrm.htm 
Figure 4. Biotechnology patents granted by the USPTO for priority years 1990 and 1997

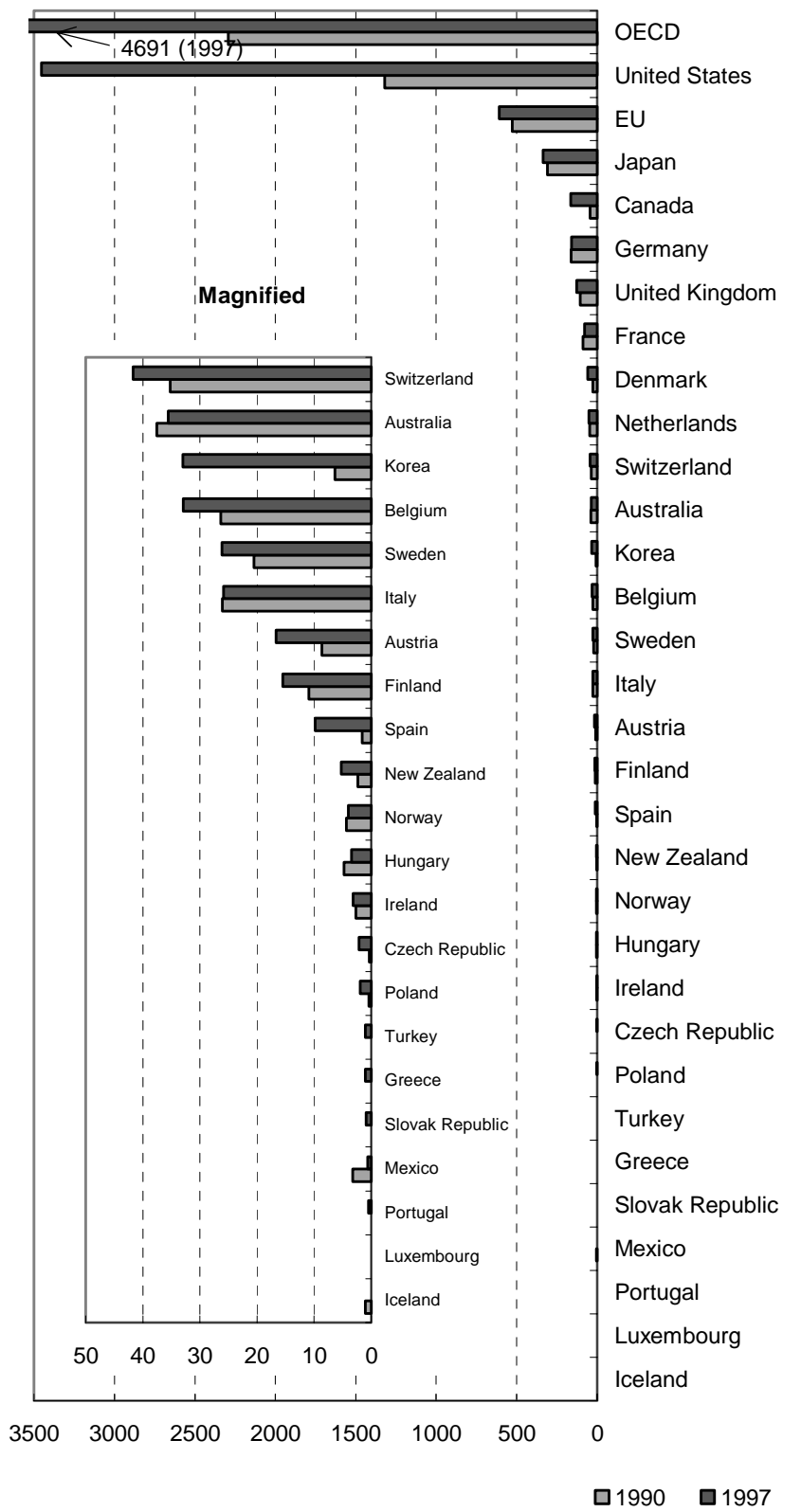

Figure 5. EPO biotechnology patent applications for priority years 1990 and 1999

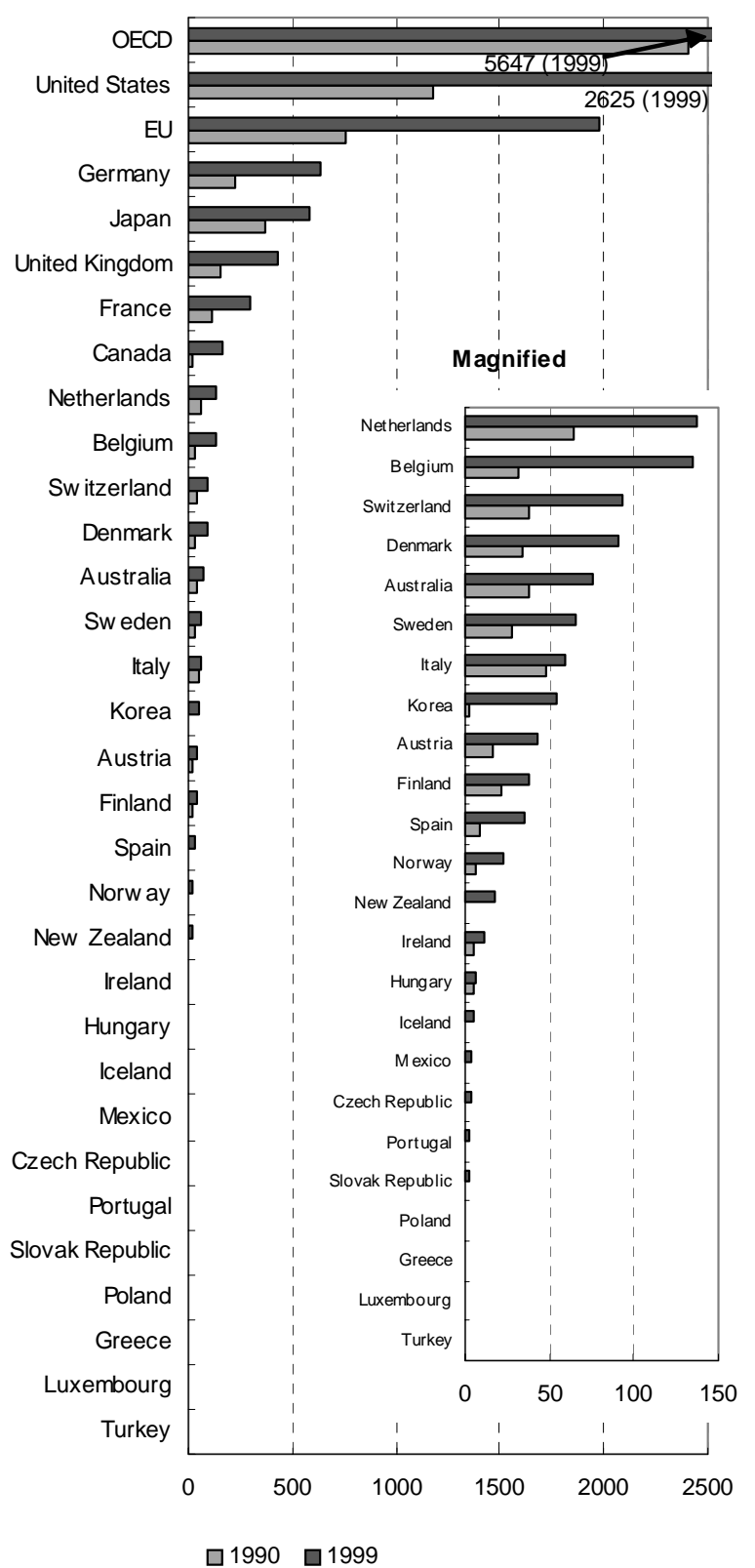

Note: The priority year refers to the first patent filing worldwide; it is the closest to the invention date.

Source: OECD, calculations based on data from USPTO and the EPO.

The six leading countries for biotechnology patent applications and patent grants according to the EPO and the USPTO respectively are six of the seven largest world economies. Italy, which is also in the G7, records only the $14^{\text {th }}$ and $13^{\text {th }}$ highest number of biotechnology patent grants and patent applications respectively in the latest year for which data are available from the USPTO and EPO.

The number of biotechnology patent applications to the EPO has grown significantly from 1990 to 1999 , increasing on average by $10 \%$ annually. Patent applications in 1999 numbered more than double those in 1990. USPTO biotechnology patents granted have increased on average by $11 \%$ annually. 
Figure 6. Share of USPTO biotechnology patents granted for priority years 1990 and 1997

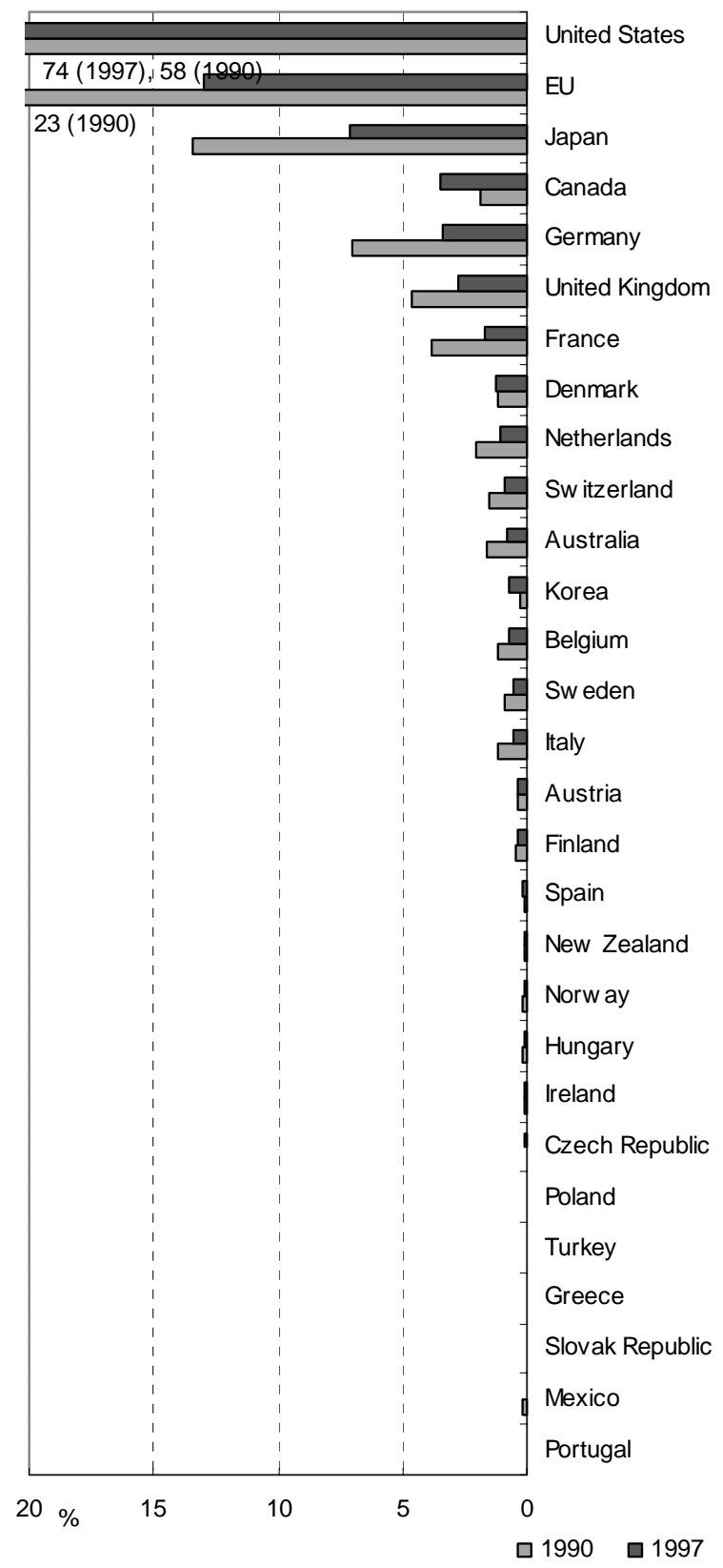

Figure 7. Share of EPO biotechnology patents as a share of total OECD biotechnology patents, 1990 and 1999

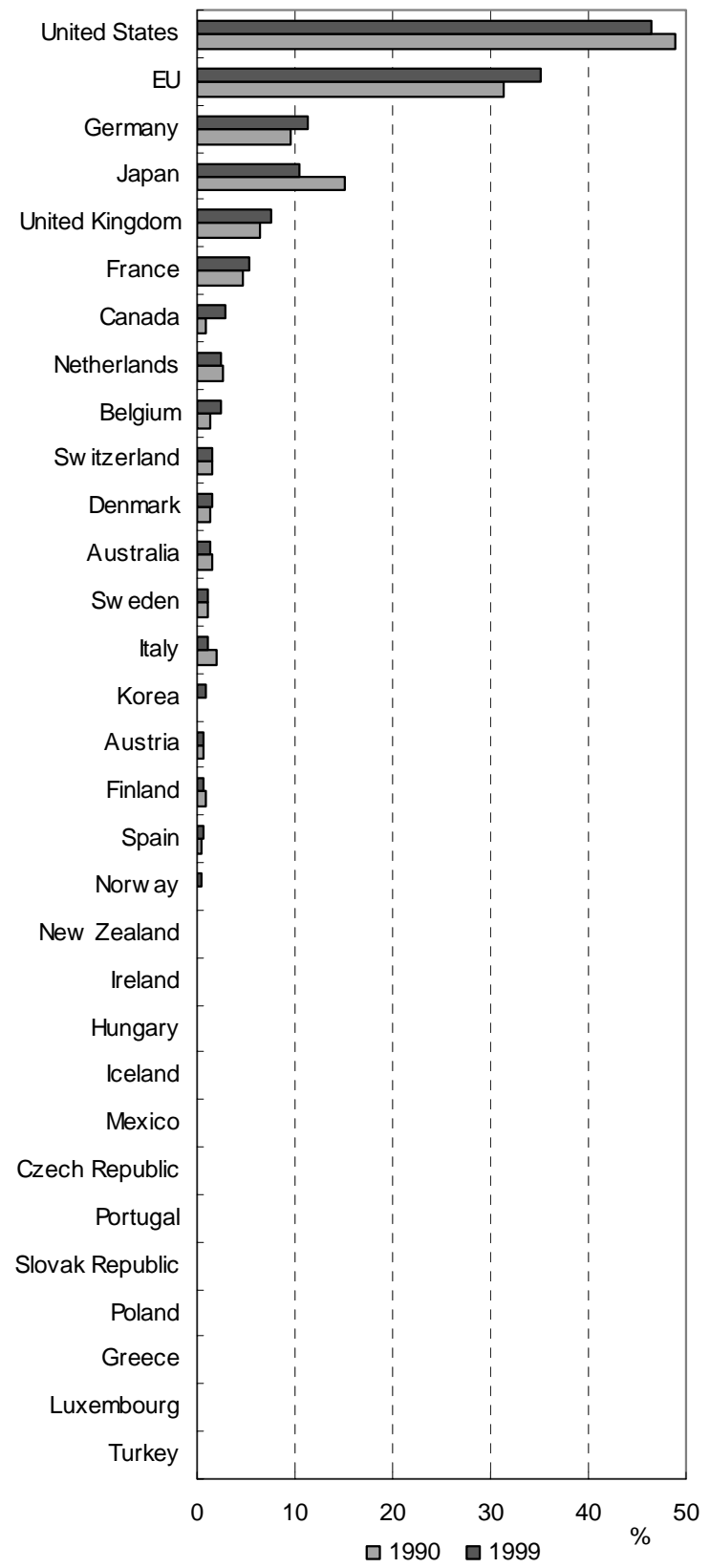

Source: OECD, calculations based on data from USPTO and the EPO.

For USPTO biotechnology patents granted between 1990 and 1997, shares have decreased markedly for the EU (10\% decrease) and Japan (6\% decrease) while increasing for the United States (an absolute increase of $16 \%)$.

Between 1990 and 1999 there has been a small shift in European and United States shares of OECD biotechnology patents. European shares increased to 35\% and US shares declined to just less than $47 \%$ of all EPO biotechnology patent applications for OECD countries. Canada and Korea also experienced gains in their shares. 
Figure 8. Average annual growth of USPTO biotechnology patents granted by priority years, 1990-1997

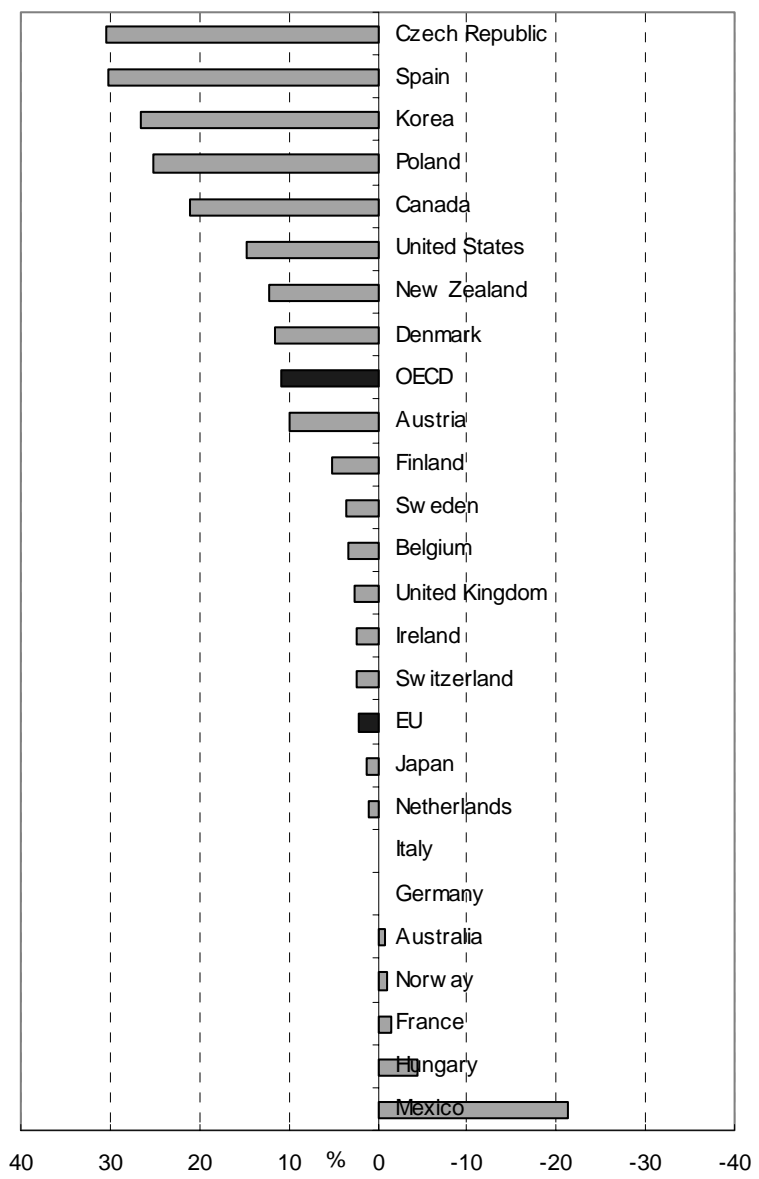

Figure 9. Average annual growth of EPO biotechnology patent applications, 1990-1999

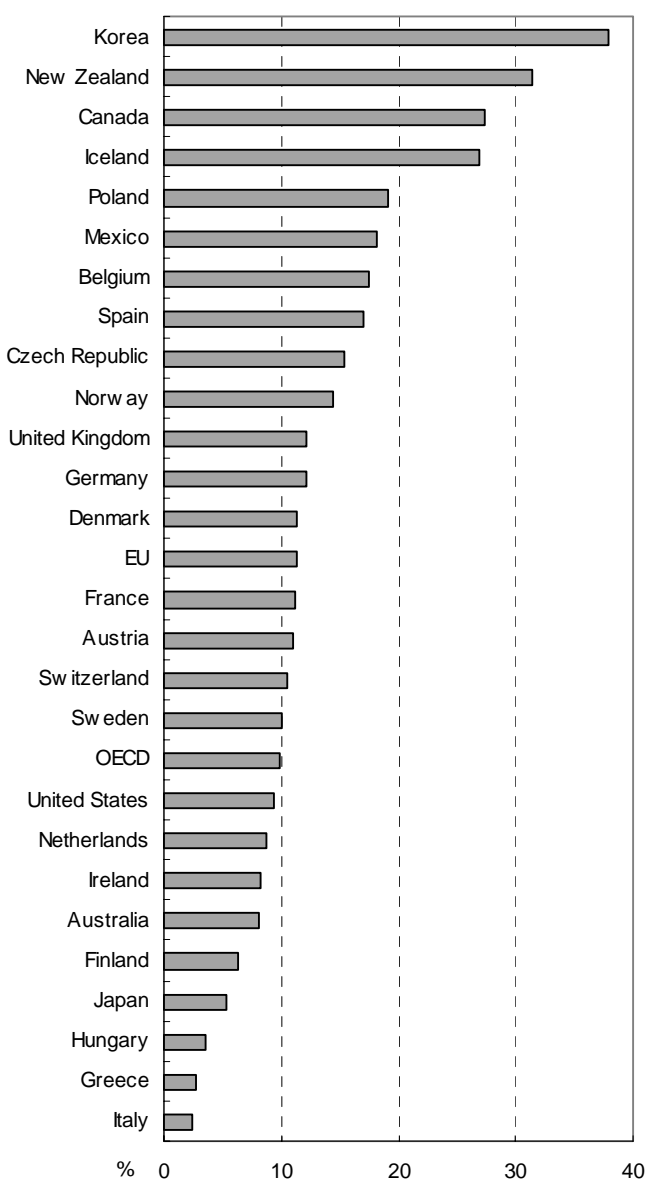

Source: OECD, calculations based on data from USPTO and the EPO.

Between 1990 and 1997, USPTO data show that OECD countries experienced an average $11 \%$ increase in biotechnology patents granted and the EU experienced a $2 \%$ increase. Within the EU, France and Germany experienced small declines from 1990 to 1997 (1.5\% and $0.1 \%$ respectively). Mexico experienced the largest decline but had very few biotechnology patents granted. The Czech Republic, Spain and Korea experienced the largest average annual increases, but all these countries started off from relatively low levels of biotechnology patents. Japan experienced a low average annual increase (1.2\%); Japanese biotechnology patents granted reached a peak in 1996.

EPO biotechnology patent applications have increased in all OECD countries from 1990 to 1999 by an average of about $10 \%$ per annum. Korea followed by New Zealand and Canada experienced the largest annual average increases in EPO biotechnology patents over this period. However, Korea and New Zealand only had three and two patents respectively in 1990. The United States, Japan and Italy, being three of the world's seven largest economies all experienced growth rates below the OECD average, with Italy experiencing the lowest growth rate in EPO biotechnology patent applications of all OECD countries. 


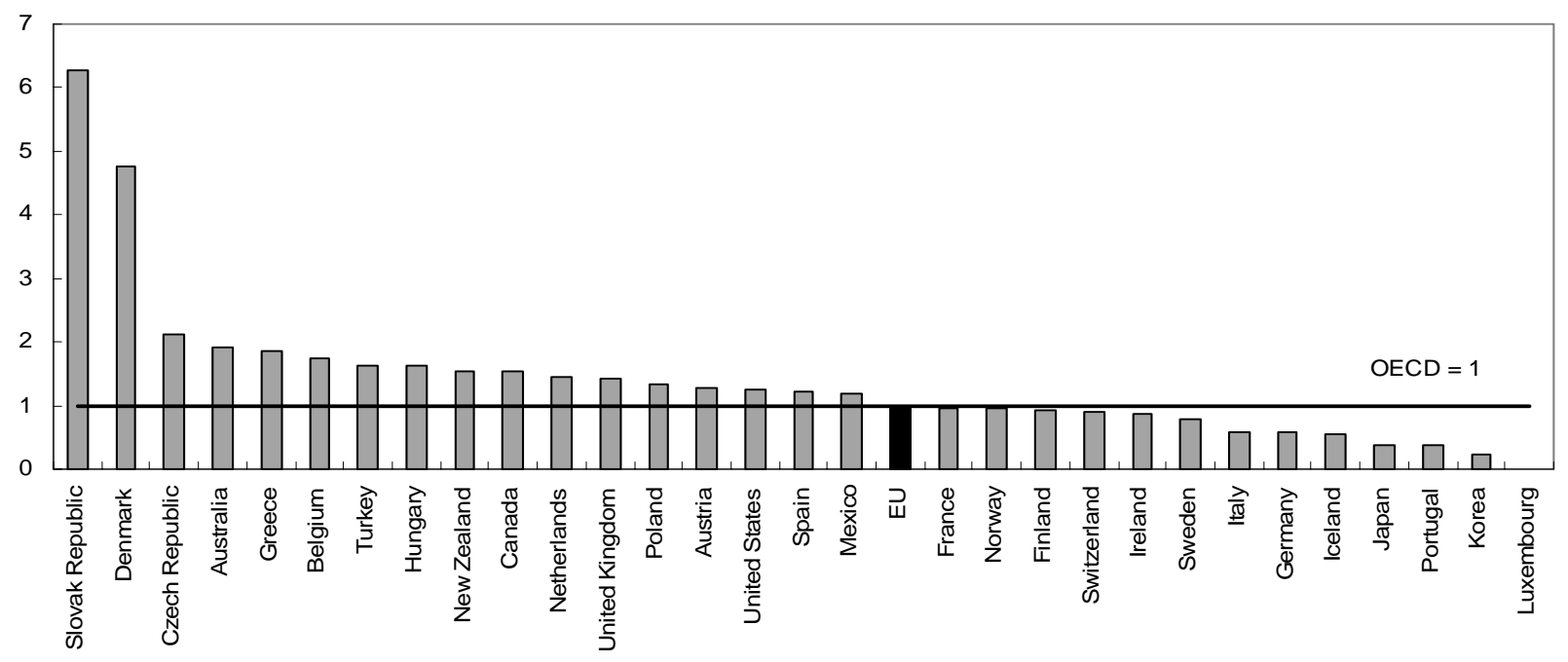

Figure 11. Average EPO biotechnology patent application specialisation index for priority years 1995-1999

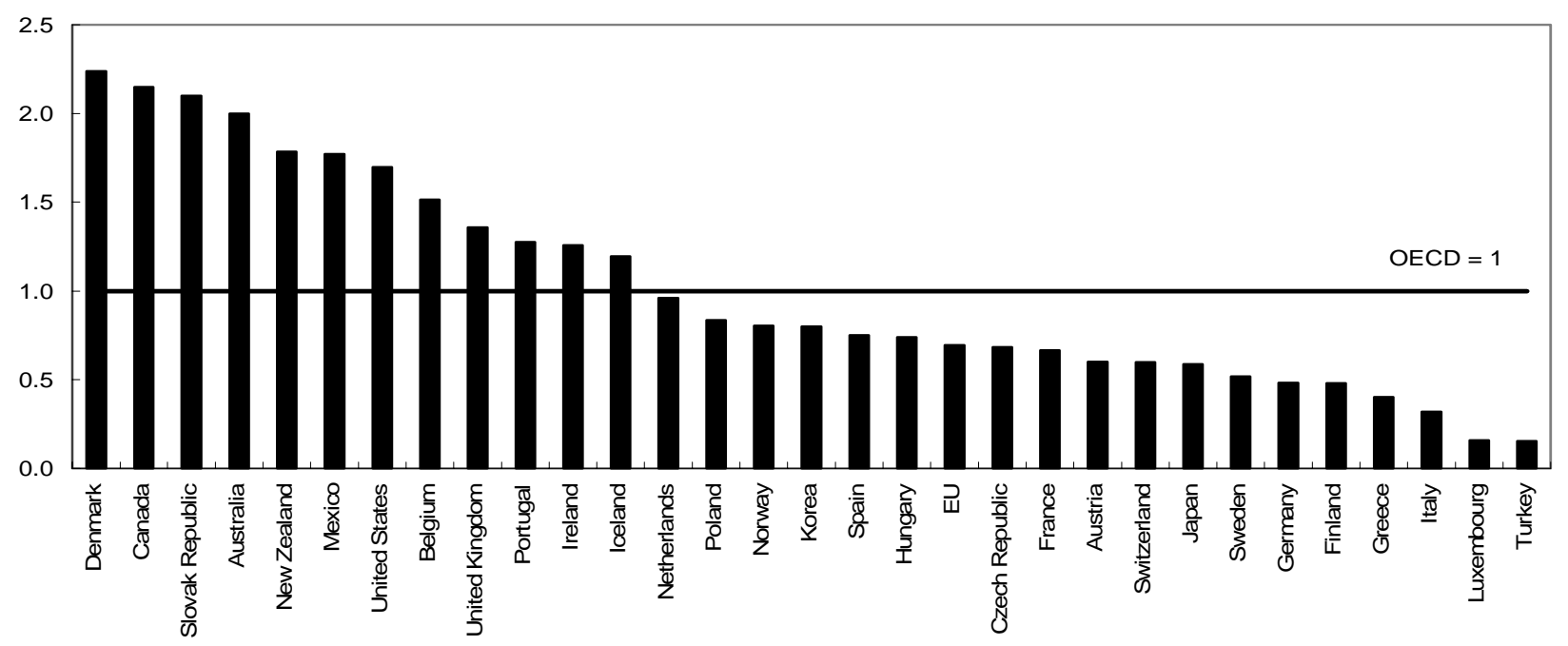

Note: For each country the specialisation index is calculated by dividing the country share of biotechnology patents into country share of total patents.

Source: OECD, calculations based on data from USPTO and the EPO.

The biotechnology patent specialisation index compares the relative importance of biotechnology patents to other patent areas within the OECD. The specialisation index is calculated as the country share in biotechnology patents over country share in total patents applications. The average specialisation index was calculated to remove the influence associated with small numbers of biotechnology patents which exist for some countries.

According to USPTO and EPO data, Denmark is relatively specialised in biotechnology patents. Excluding the Slovak and Czech Republics which have few patents granted, Australia is also relatively specialised in USPTO biotechnology patents granted. Denmark and Canada are the two EPO countries with the highest index of biotechnology patent specialisation - both countries have an index of 2.2. 


\section{BIOTECHNOLOGY VENTURE CAPITAL INVESTMENT}

\section{Box 4. Venture capital data}

Venture capital is a high risk fund-raising technique for companies wanting to exchange equity for capital.

There are two main sources of venture capital:

- Specialized financial firms. These act as intermediaries between primary sources of finances (such as pension funds or banks) and firms. They provide formal venture capital.

- "Business angels". These are usually wealthy individuals experienced in both business and finance who invest directly in firms.

Venture capital data are collected by national or regional venture capital associations from their members. Statistics only capture formal venture capital. As business angels are excluded, international comparisons may be affected since in the United States business angels have tended to invest much more in new firms than venture capital funds. This is probably much less the case in other OECD member countries.

The developments of a venture-backed company has three basic financing stages:

- $\quad$ Seed capital is provided to research, assess and develop an initial concept.

- $\quad$ Start-up financing is provided for product development and initial marketing. Companies may be being set up or may have been in business for a short time, but have not yet sold their product commercially.

- Expansion financing is provided for the growth and expansion of a company that is breaking even or trading profitably. Capital may be used to finance increased production capacity, market or product development and/or to provide additional working capital.

The data used for the following graphs and accompanying analysis are mainly drawn from four sources: The US National Venture Capital Association (NVCA), the European Venture Capital Association (EVCA), the Canadian Venture Capital Association (CVCA) and the Asian Venture Capital Journal (AVCJ). Unfortunately, information on venture capital investments in Asia does not allow the separate identification of biotechnology in the overall medical sector.

Note that for several countries - Poland, Norway, Ireland - the number of deals remains quite small. Therefore one big or relatively small deal could significantly alter the final picture. 


\section{Biotechnology venture capital}

The United States remains the main market for venture capital for biotechnology firms, despite a decrease from 2000 to 2001 of USD 785 million. In 2001, biotechnology venture capital in the United States amounted to USD 3419 million which accounted for 74\% of biotechnology venture capital investment in the OECD. By comparison, biotechnology venture capital in Europe amounted only to USD 745 million $(16 \%)$.

The main European contributor to biotechnology venture capital investment is Germany (60\% of the EU total). Germany is followed by the United Kingdom (10\%) and France (9\%) respectively.

From 1995 to 2001 the US experienced an average annual growth rate in biotechnology venture capital investment of $27 \%$. In comparison, the European Union experienced a slightly faster average annual growth rate of $30 \%$.

Biotechnology venture capital expressed per million units of GDP has increased for most OECD countries from 1995 to 2001. The largest absolute increase between 1995 and 2001 occurred in Canada. However, Denmark and Germany, which started from low levels in 1995, also experienced significant increases in biotechnology venture capital.

\section{Sources}

US National Venture Capital Association (NVCA), Thomson Venture Economics 2002 Yearbook and earlier editions.

European Venture Capital Association (EVCA): Annual Survey of Pan-European Private Equity and Venture Capital Activity, ECVA Yearbook, June 2002 and earlier editions.

Canadian Venture Capital Association (CVCA), www.cvca.ca/statistical_review/

Asian Venture Capital Journal (AVCJ). The 2003 Guide to Venture Capital in Asia, November 2002 and earlier versions. 
Figure 12. Biotechnology venture capital investment shares in 2001

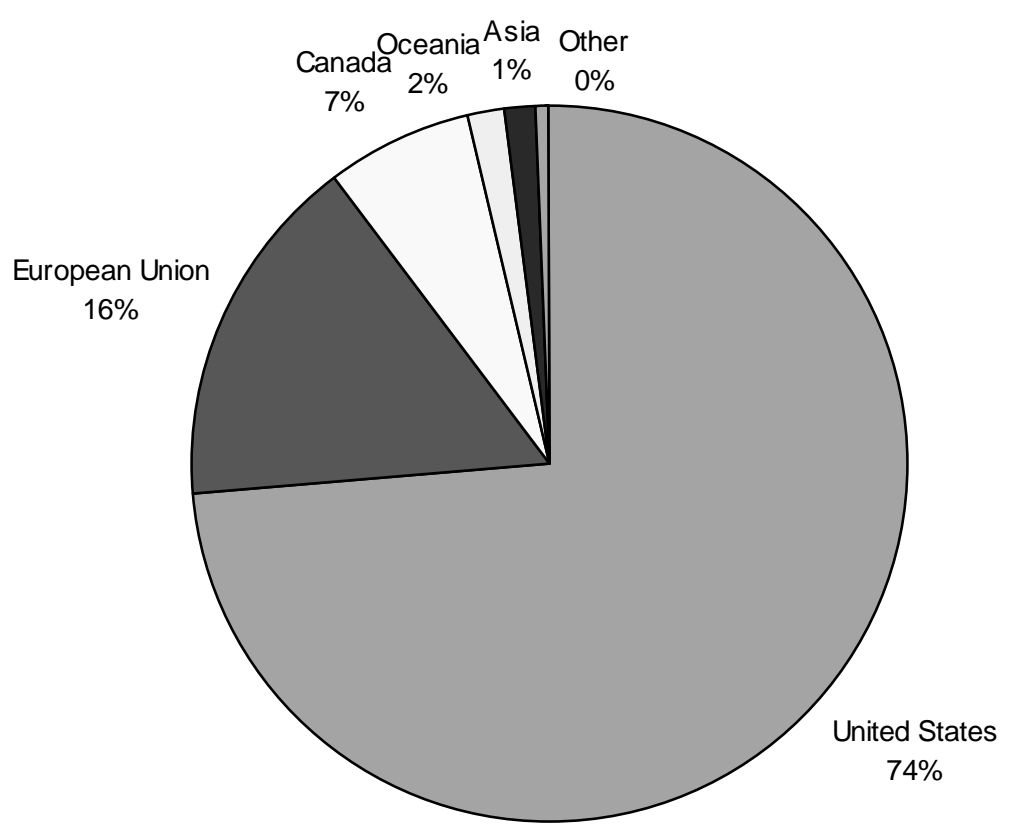

Figure 13. Biotechnology venture capital investment per million units of GDP, 1995 and 2001

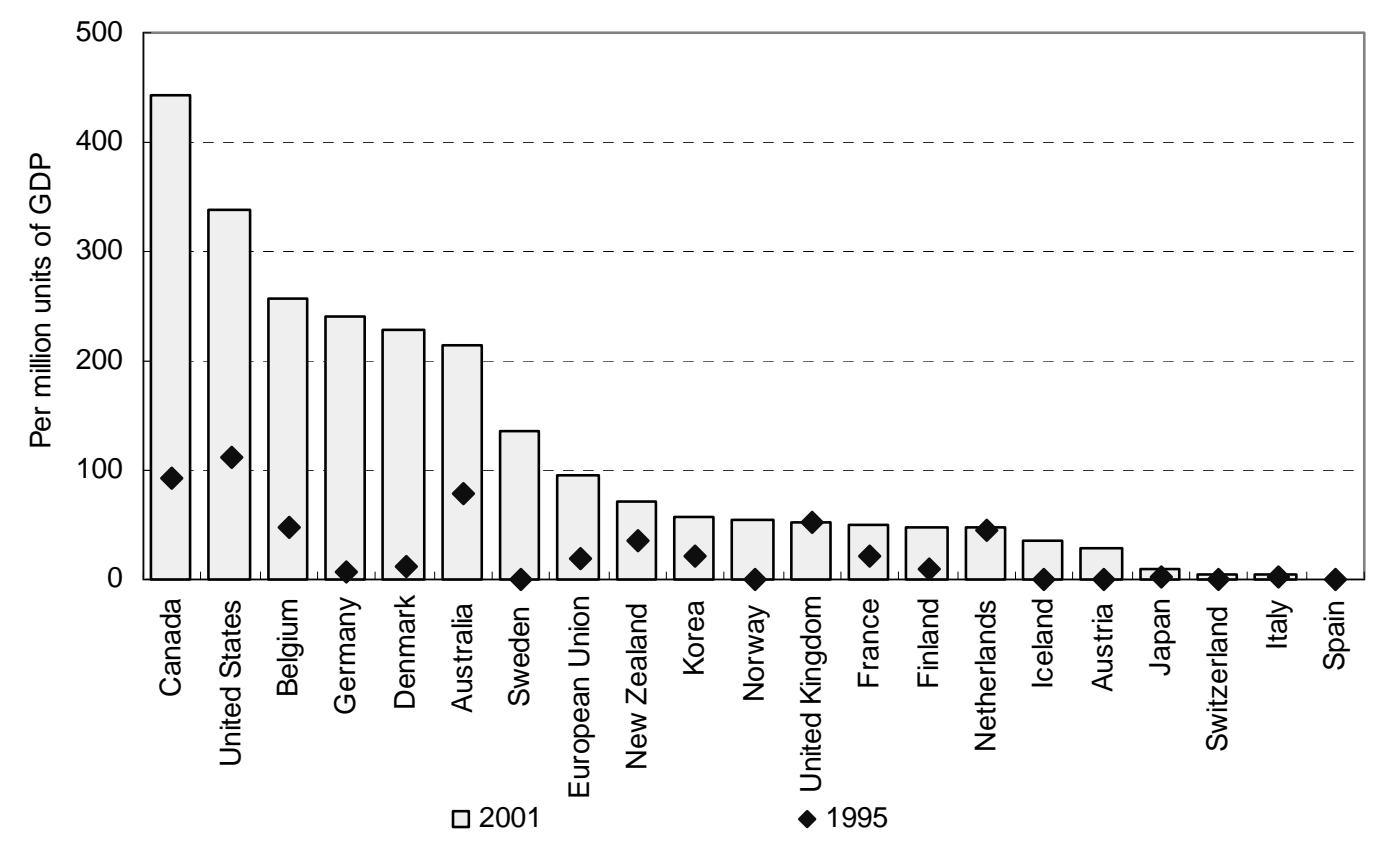

Note that data for Australia, Japan, Korea and New Zealand are for medical/biotechnology venture capital combined.

Asia corresponds to Japan and Korea, Oceania refers to New Zealand and Australia. Other includes Czech Republic, Hungary, Iceland, Norway, Poland, Slovak Republic and Switzerland.

Source: The European Venture Capital Association for European countries, the Asian Venture Capital Journal (Yearbook) for Australia, New Zealand, Japan and Korea and the National Venture Capital Association for the United States. 


\section{GENETICALLY ENGINEERED CROPS}

The area covered by genetically engineered crops has increased over the past seven years, reaching 58.7 million hectares in 2002. The United States, with 39 million hectares of genetically engineered crops, represents $66 \%$ of the global total of genetically engineered crops by area. Argentina and the United States account for $89 \%$ of all genetically engineered crops. The area covered by genetically engineered crops is expected to continue its increase.

The main genetically engineered crops are soybeans, corn, cotton and canola. Genetically engineered soybean crops account for close to half of all world soybean crops.

Table 2. Genetically engineered crops (millions of hectares), 2002

\begin{tabular}{|l|rrrrrrr|}
\hline & 1996 & 1997 & 1998 & 1999 & 2000 & 2001 & 2002 \\
\hline Argentina & 0.1 & 1.4 & 4.3 & 6.7 & 10 & 11.8 & 13.5 \\
Australia & $<0.03$ & 0.05 & 0.1 & 0.1 & 0.15 & 0.2 & n.a \\
Canada & 0.1 & 1.3 & 2.8 & 4 & 3 & 3.2 & 3.5 \\
China & 1.1 & 1.8 & n.a & 0.3 & 0.5 & 1.5 & 2.1 \\
France & 0 & 0 & $<0.1$ & $<0.1$ & 0 & 0 & n.a \\
Mexico & 0 & 0 & $<0.1$ & $<0.1$ & $<0.1$ & $<0.1$ & n.a \\
Portugal & 0 & 0 & 0 & $<0.1$ & $<0.1$ & $<0.1$ & n.a \\
Spain $_{\text {United States }}^{1}$ & 0 & 0 & $<0.1$ & $<0.1$ & $<0.1$ & $<0.1$ & n.a \\
World $^{2}$ & 1.5 & 8.1 & 20.5 & 28.7 & 30.3 & 35.7 & 39.0 \\
\hline
\end{tabular}

Notes:

1. The US Department of Agriculture estimates differ from the above industry estimates as follows: 1996: 3.2 million hectares; 1998: 20.23 million hectares.

2. 1998 figure excludes China.

3. n.a $=$ not available.

Sources: James, C. (1997-2002), "Global Review of Transgenic Crops", ISAAA Briefs, 1997-2002 various editions, The International Service for the Acquisition of Agri-biotechnology Applications (ISAAA), Ithaca, New York, United States.

\section{Source}

James, C. (2002): "Global Review of Commercialised Transgenic Crops" (2001), www.isaaa.org Web site. 
DSTI/DOC(2003)13

\section{COUNTRY PROFILES}

\section{Box 5. Country profiles using official statistics}

This section contains country-specific data. As biotechnology statistics have not yet been harmonized across countries there is still a wide variation in the information that countries collect. No attempt has been made to limit the data in this section to comparable indicators across the countries; therefore the indicators presented vary across countries. The data that is presented is not exhaustive but rather an example of the range of data that is available for a particular country. Data often comes from surveys, whether they be regular national surveys (e.g. Canada R\&D) or specific one-off surveys (e.g. Finland's ETLA survey on biotechnology firms).

Note that for countries in the European Union funding data refers to how much the national governments allocate to biotechnology and do not include the contributions from the European Commission. Consequently, biotechnology funding spent in a European Union country will be underestimated. 


\section{Australia}

\section{Personnel}

The Australian Bureau of Statistics reported that there were a total of 3970 person years in 2000/01 devoted to biotechnology R\&D. Of this the higher education and the business sectors accounted for $36 \%$ and 30\% respectively. Approximately two-thirds of biotechnology R\&D person years in the higher education sector and business sector were in the genetics area and the industrial biotechnology area respectively.

Figure 14. Biotechnology R\&D person years, 2000-01

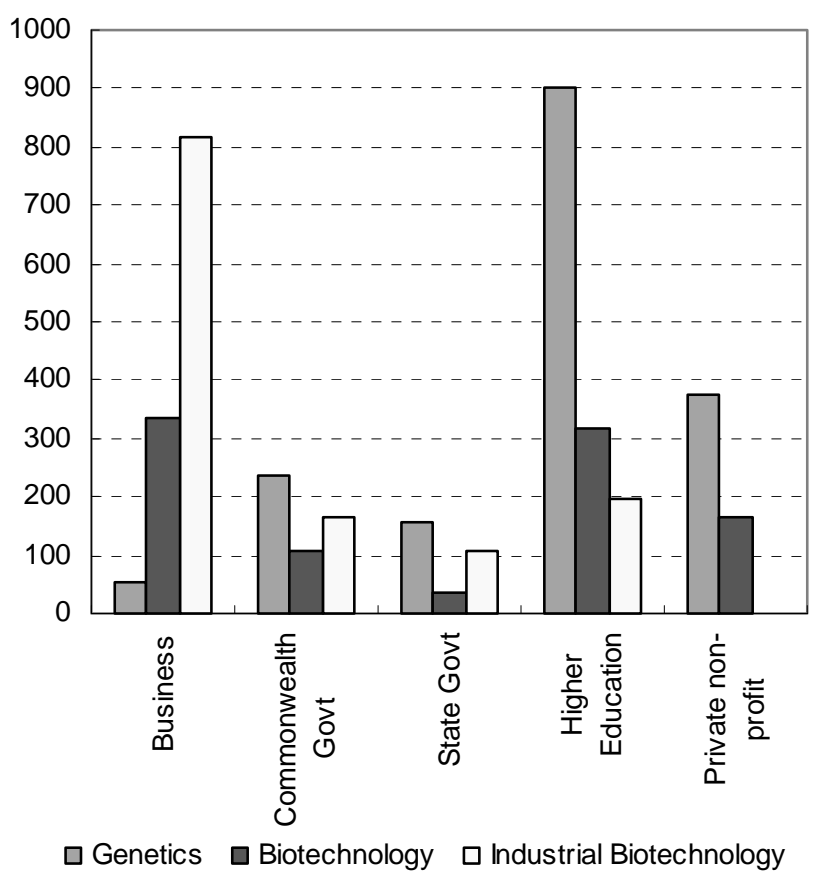

Figure 15. Biotechnology R\&D expenditure, 2000-01

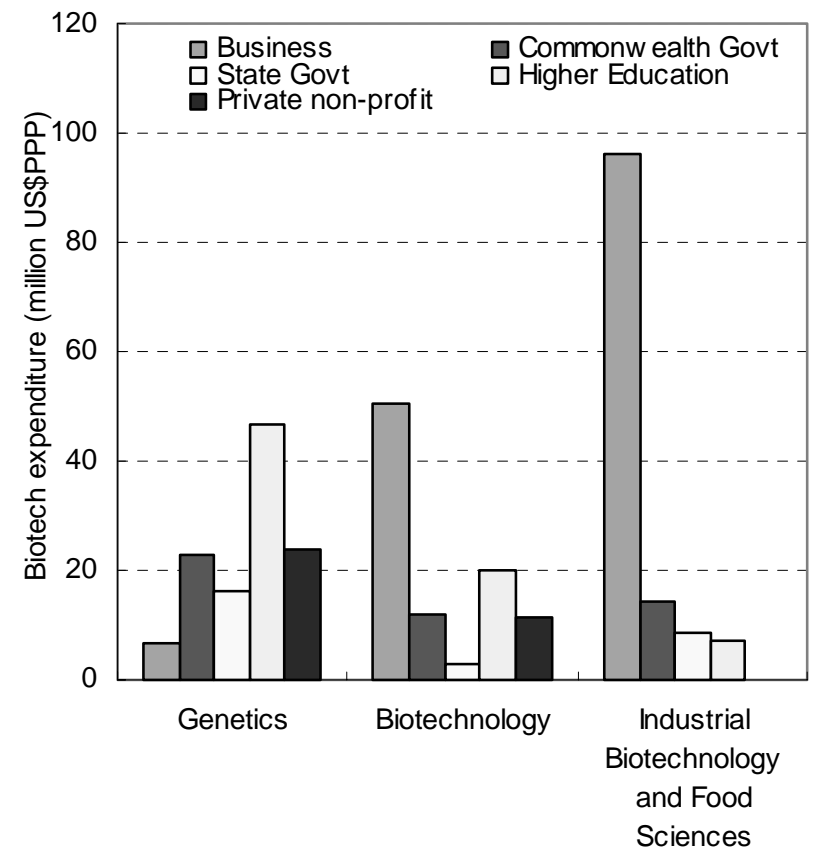

Source: OECD calculations based on the Australian Bureau of Statistics Survey of Research and Experimental Development data.

\section{Research and development}

Research and development (R\&D) data for Australia for the latest year (2000-01) show that businesses perform the largest share of biotechnology R\&D in Australia, accounting for almost half of all biotechnology R\&D expenditure. In 2000-01, businesses spent USD 153 million on biotechnology R\&D (PPP adjusted). The sector with the next highest share of biotechnology R\&D expenditure was the government sector which reported expenditure half that of the business sector.

Biotechnology has been defined according to Fields of Research (categories 270200 genetics, 270800 biotechnology and 290100 industrial biotechnology and food sciences in the Australian Standard Research Classification, 1998). It should be noted that these categories would not cover all activity considered to be biotechnology, and may include some that are not. The business sector carried out the majority of its R\&D expenditure in the industrial biotechnology and food sciences field. In comparison, the government, higher education and private non-profit sectors each carried out the largest share of their R\&D expenditure in the genetics field.

The state and commonwealth governments spent USD 76 million (PPP adjusted) on biotechnology R\&D in 2000/01. The higher education sector spent USD 74 million (PPP adjusted). 
In 1999 the three sectors with the greatest number of products under development were human health, agriculture and equipment and services.

\section{Funding}

In 2000-01 government budget appropriations or outlays on biotechnology R\&D amounted to AUD 307 million, representing $8 \%$ of total government budgetary appropriations or outlays on R\&D. Note that this is prior to allocation of AUD 30.5 million (2001 to 2004) to support targeted initiatives under the biotechnology strategy. A major component of this strategy is the allocation of AUD 20 million to support early stages of commercialisation.

In 2000-01 the three largest receivers of publicly funded biotechnology R\&D funds were Universities (29\%), the National Health and Medical Research Council (18\%) and the Commonwealth Scientific and Industrial Research Organisation (15\%).

\section{Brief policy overview}

In July 2000 the Australian government released a national biotechnology strategy. The government's main areas for biotechnology research are human health and the environment. The government is particularly concerned about safeguarding human health and the environment through appropriate and transparent regulation. Like other countries isolated from large markets, Australia is keen to attract resources for biotechnology and, in particular, management and entrepreneurial skills in the biotechnology sector. The national strategy aims to increase the economic and community benefits of biotechnology and to develop an infrastructure for promoting biotechnology applications.

As in many countries, the Australian public has a negative perception of biotechnology. The national strategy also aims to address public concerns with particular regard to agriculture and food.

For 2003 the Australian government intends to evaluate the national biotechnology strategy and to map out a biotechnology industry growth plan for the future. Bioinformatics and bioprocessing are two areas which the government is especially interested in developing national strategies.

In May 2002, the government announced that AUD 43.55 million will be allocated to the National Stem Cell Centre over four years, which "will pursue a broad scope of research involving both adult and embryonic cells, including treatments for diabetes; vascular, bone and nerve damage; kidney disease, and diseases of the blood and skin." as part of the Government's desire to "achieve excellence in both research and commercialisation and to develop capabilities in key biotechnology platform technologies".

\section{Sources}

Australian Bureau of Statistics, Survey of Experimental Research and Development.

Commonwealth of Australia, Ernst and Young and Freehills, 2001. Australian Biotechnology Report 2001.

Department of Industry, Tourism and Resources Web page www.industry.gov.au/factsheets

National Biotechnology Strategy, (July 2000), http://www.biotechnology.gov.au

National Health and Medical Research Council website: www.health.gov.au/nhmrc/ 


\section{Austria}

\section{Funding}

In June 2001 the Austrian council for research and technological development recommended the creation of a programme for genome research with funds of EUR 31.74 million. This project should foster links between universities and businesses with results expected in medicine, environment or food production. The council also recommended EUR 25.12 million is allocated to biotechnology and bio-medicine. These two areas contribute to the majority of the biotechnology R\&D funding for 2001-2003 - a total of EUR 78.17 million, or approximately EUR 26 million per year (Austrian Council for Research and Technological Development).

From 1994 to 1998, the European Biotechnology Innovation System report indicates that public funding of biotechnology in Austria is predominantly in the bio-pharma area (Baier et al.).

Health-related biotechnology, bio-knowledge and genomes are mentioned as being among the seven priority areas for Austria (Austrian Council for Research and Technological Development).

\section{Sources}

Austrian Council for Research and Technology Development, Tätigkeitsbericht, downloaded from the website: www.bmvit.gv.at

Baier et al, (October, 2000). European Biotechnology Innovation System (EBIS), "National Case Study of Austria". www.sussex.ac.uk/spru/biotechnology/ebis/austria.pdf 


\section{Belgium}

\section{Enterprises}

Results from the first Belgium Use and Development Survey released in July 2003 showed that there were 57 biotechnology companies in 2003. Companies engaged in the pharmaceutical sector accounted for almost one quarter of all biotechnology companies in Belgium. By comparison two out of three people engaged in biotechnology employment in Belgium are employed in the pharmaceutical sector.

Almost half of all biotechnology firms in Belgium are in an expansion phase. A further $40 \%$ are in either the start-up or early stage of development.

One-third of biotechnology companies who needed financing approached the business founders. Shareholders, followed by the public, were the next two main sources of financing, accounting for relative shares of $20 \%$ and $15 \%$ respectively. Just over half of the 11 biotechnology companies who raised equity capital in 2002 raised an amount less than EUR 1 million.

\section{Personnel}

$40 \%$ of Belgium's biotechnology companies have between one and nine members of staff. Four out of five biotechnology companies have fewer than 100 employees, indicating that biotechnology enterprises in Belgium are primarily small and medium sized enterprises. In a biotechnology enterprise some employees are not doing biotechnology work (e.g. administration). Smaller enterprises are associated with a higher proportion of staff who are employed in biotechnology. Approximately $60 \%$ of enterprises with less than 50 staff members are engaged in biotechnology employment, compared with only $20 \%$ for companies with more than 500 staff members.

\section{Research \& Development}

In 2003, biotechnology companies spent a total of EUR 409 million on biotechnology R\&D representing an increase of $13 \%$ from 2001. For biotechnology companies in 2001, the share of biotechnology R\&D in total R\&D was $46 \%$, which increased to $51 \%$ in 2003.

\section{Source}

Tiri, M et al. (2003), Biotechnology in Belgium: First results of the Belgian Biotechnology Use and Development Survey. 
Figure 16. Biotechnology companies by sector, 2003 Figure 17. Biotechnology companies by number of employees, 2003
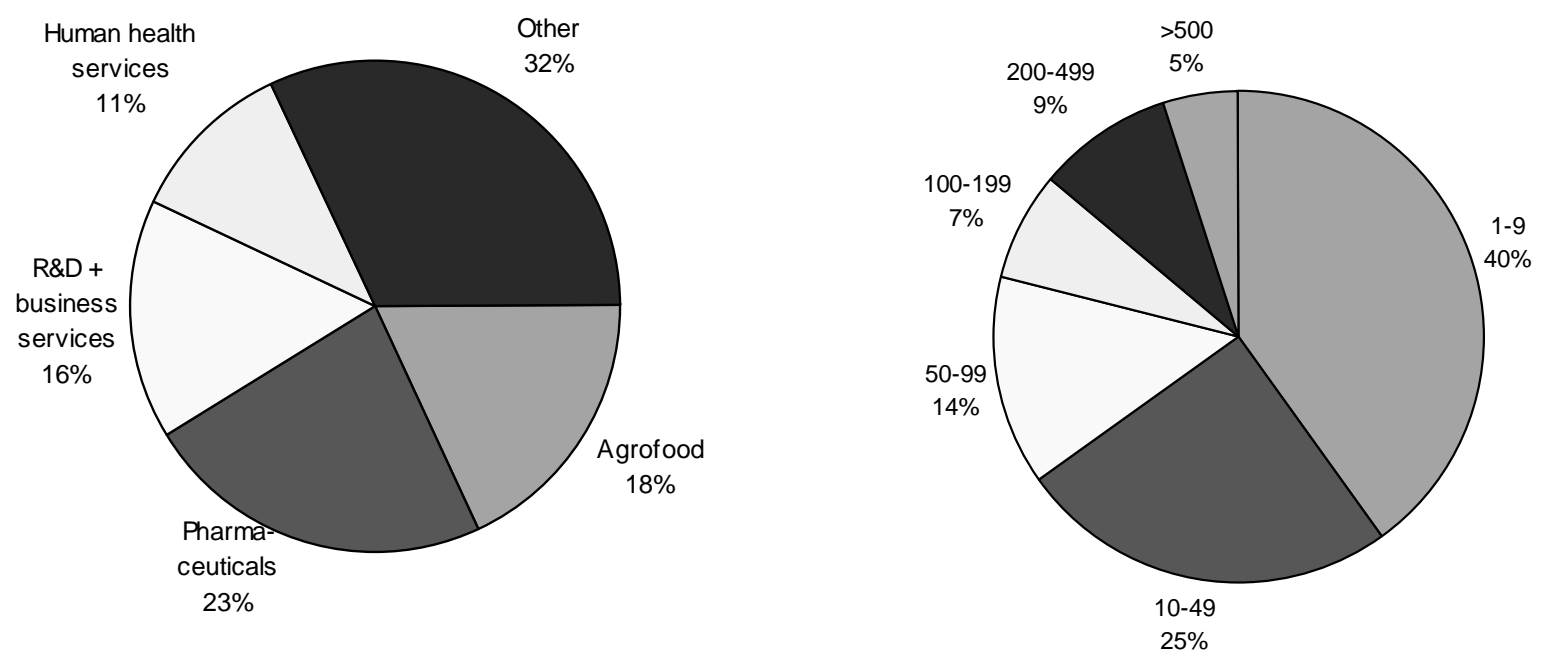

Figure 18. Use and development of biotechnology, 2003

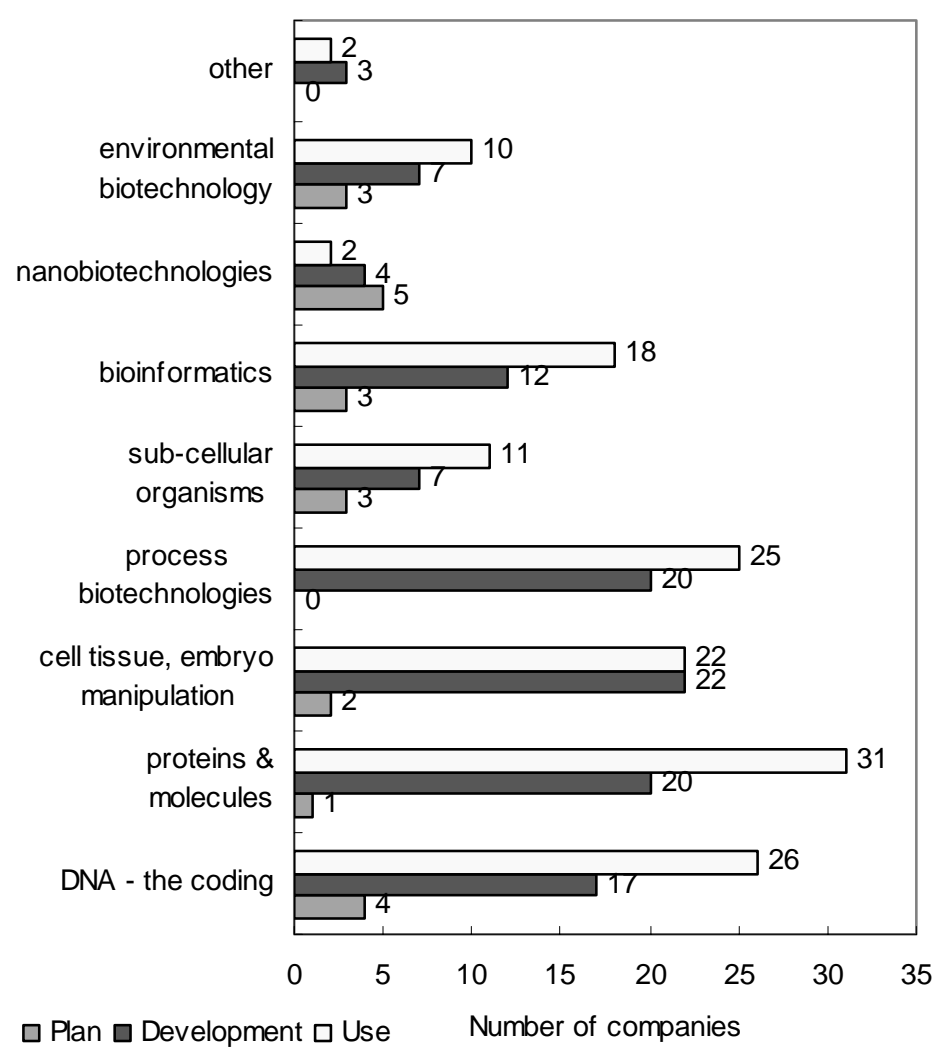

Source: Tiri, M. et al., Biotechnology in Belgium: First Results of the Belgium Biotechnology Use and Development Survey 2003. 


\section{Canada}

\section{Enterprises}

Based on responses from the 2002 Biotechnology Use and Development Survey, Statistics Canada reported that there were 375 biotechnology innovative firms in 2001, an increase of 5\% from the previous survey results for1999. Just over half of all biotechnology innovative firms were active in the human health field. The human health sector has grown in size from 150 firms in 1999 to 199 firms in 2001. By comparison, the agriculture sector declined in size from 90 firms in 1999 to 67 in 2001. Statistics Canada attributes this decline to several factors, including a shift from the agriculture sector to the food-processing sector and to a ceasing of operations.

According to the Canadian Biotechnology Advisory Committee (CBAC) 2000-01 annual report, Canada has the most biotechnology companies per capita in the world.

\section{Revenue}

Revenues from biotechnology exceeded CAD 1.9 billion (USD PPP 1.6 billion) with the human health field accounting for 53\% of total biotechnology revenues. Average biotechnology revenues from core biotechnology firms have increased the fastest from 1997 to 1999 in the health sector with average revenue doubling in two years. Overall average biotechnology revenue from core biotechnology firms increased on average by $31 \%$ annually. The big increase in average revenue attributed to the "other" category indicates the presence of biotechnology activities in a diversity of sectors. Bioinformatics is an example of a new area that is becoming increasingly important to biotechnology in Canada. Statistics Canada predicts that due to the shorter time frame to pass through the life cycle of bioinformatics than other biotechnology areas, they expect a significant increase in revenues from this sector over the next few years.

\section{Personnel}

Statistics Canada estimated that in 2001-02, 1500 person years were engaged in federal government biotechnology science and technology activities. Research and development account for about $96 \%$ of total science and technology activities. Full-time biotechnology employees are predominantly classified as either involved in scientific and professional or in technical activities. The total number of biotechnology employees increased 95\% from 1997 to 2001.

Biotechnology firms with more than 150 employees account for approximately half of total biotechnology employment. While large firms employ the largest share of human resources in biotechnology, it is small firms (less than 50 employees) which are the most numerous, accounting for almost three in four biotechnology innovative firms (Statistics Canada Innovation Analysis Bulletin, 2003).

One of the 15 targets that the Canadian government has set to ensure that Canada becomes one of the most innovative countries in the world is to increase the numbers of $\mathrm{PhD}$ and masters students by an average of 5\% per year up to 2010 (Canadian government Web site).

\section{Funding}

Canada has had a national biotechnology strategy since 1981. In 1981 the Canadian government allocated CAD 10 million to the strategy (Statistics Canada). In 2001-02, the Canadian federal government spent CAD 494 million on biotechnology research and development. Added to this is another CAD 19 million for related scientific activities leading to a total of CAD 513 million spent on Federal biotechnology activity. Federal biotechnology research and development expenditure has increased $30 \%$ over two years (CAD 380 million for R\&D in 1999-2000). 
Figure 19. Canadian biotechnology innovative firms by sector

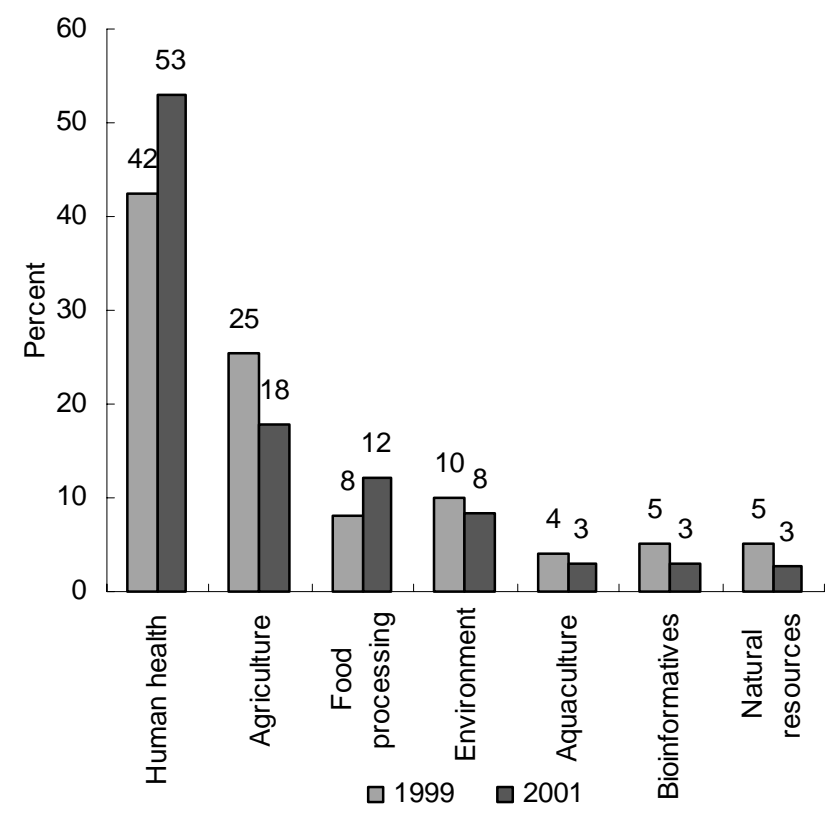

Figure 21. Biotechnology firms by firm size and employment

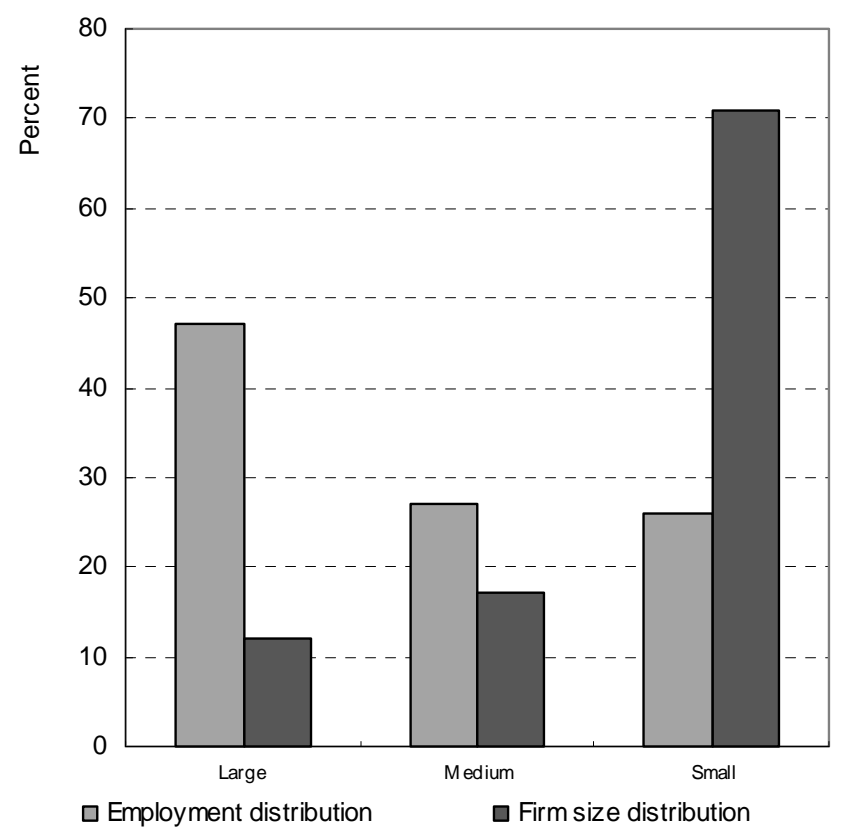

Figure 20. Biotechnology firms by type of position

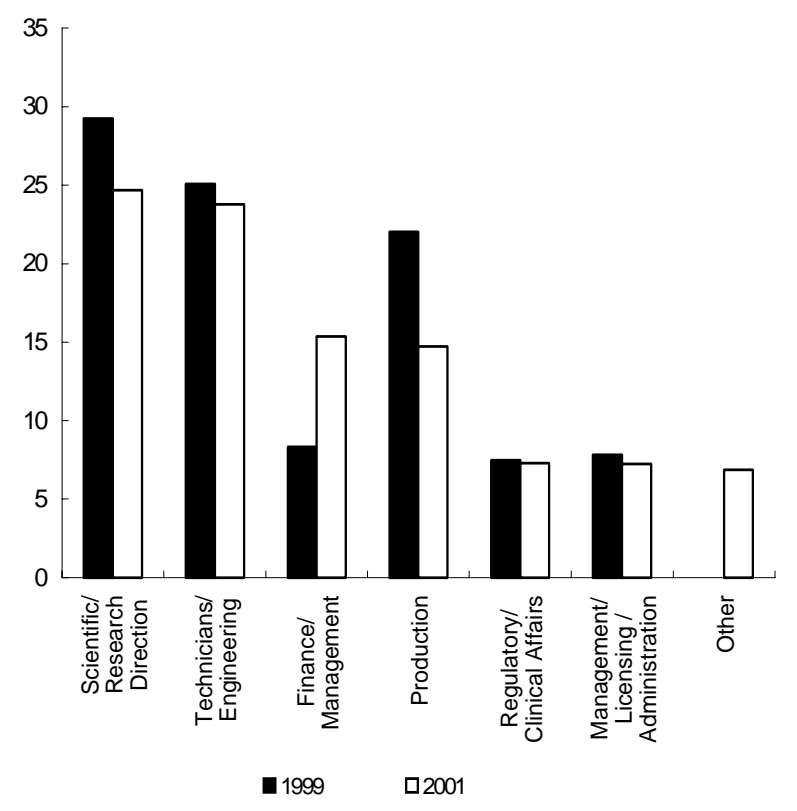

Figure 22. Average biotechnology revenues by sector from core biotechnology firms, USD PPP

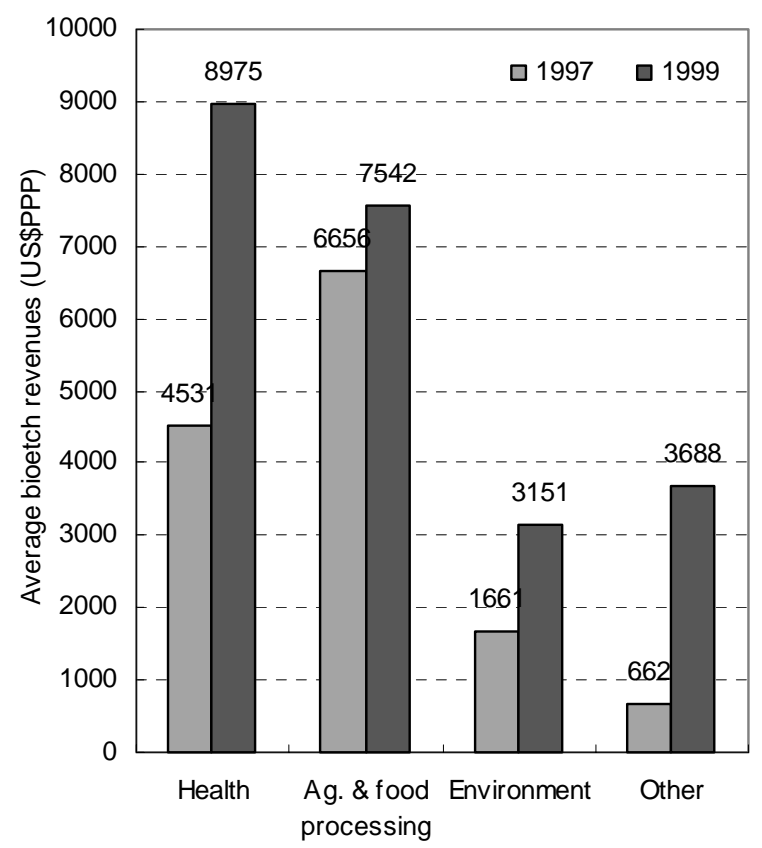

Source: Statistics Canada, Innovation Analysis Bulletin - Vol. 5, No. 1 (February 2003), and "How is the Canadian Biotechnology evolving: a comparison of the 1997 and 1999 biotechnology use and development surveys", March 2003. PPP calculations were performed by the OECD. 
In 2001-02 almost 55\% of federally funded biotechnology science and technology activities funded were performed outside of federal government, with the largest recipient - the higher education sector receiving CAD 164 million.

\section{Brief policy overview}

In 1998 the Canadian government launched a new national biotechnology strategy. The renewed strategy integrated social, ethical, health and economic, environmental and regulatory components. In 2001 the Canadian Biotechnology Advisory Committee (CBAC) devoted the most time to genetically modified foods and the patenting of higher life forms. Stem cells and cloning dominated the headlines in 2001. Agricultural biotechnology also featured highly on the public agenda. As far as federal R\&D funding is concerned, approximately 85\% of 2001-2002 R\&D funds are allocated to Agriculture and Agri-food Canada (CAD 64 million) or to the Medical Research Council (CAD 126 million).

In 2002 the Canadian government published a preliminary report on the BIOTECanada's innovation roundtable. This report made several recommendations to develop the biotechnology industry. The federal government has made significant investments in biotechnology $R \& D$ in recent years, but recommended allocating more funding to biotechnology $\mathrm{R} \& \mathrm{D}$, particularly from the Technology Partnerships Canada budget (TPC). TPC has an annual biotechnology budget of CAD 25 million. After research the next step is to foster the commercialisation of research. In particular the report emphasises the biopharmaceutical sector, where it points out that by depending on the United States for pharmaceuticals will cost Canada a significant amount in exchange rates alone.

Another recommendation was to extend the current scientific research and experiment tax credit programme, especially in terms of the expenditure cap and the length of time that a company is eligible for tax credits. The report also recommended that the government amend the regulatory system which results in slow approval times for new biotechnology products. Average approval time for new drugs in Canada is 608 days compared with 496 days in the United States and a low of 344 days in the United Kingdom.

Human resources are important in research. Often companies require multi-disciplinary biotechnology employees, so programmes training people in science, computer technology, engineering and business have recently been established, such as the Masters of Biotechnology in Toronto.

\section{Sources}

Canadian Biotechnology Advisory Committee, 2001-2002 Annual Report. http://www.cbac-cccb.ca/

Canadian government Web site: http://www.innovationstrategy.gc.ca/cmb/innovation.nsf/MenuE/InnovationTargetAnalysis

Canadian government Web page. “Advancing Canada's Innovation Agenda: Realising Biotech's Potential". "A Preliminary Report to Industry Canada on BIOTECanada's Innovation Roundtable". www.innovationstrategy.gc.ca

Statistics Canada, How is the Canadian Biotechnology evolving: A comparison of the 1997 and 1999 Biotechnology Use and Development surveys, March 2003. Available on the Internet at: http://www.statcan.ca/english/IPS/Data/88F0006XIE2003003.htm

Statistics Canada, Innovation Analysis Bulletin, Vol. 5, No. 1 (February 2003). Available on the Internet at http://www.statcan.ca/english/freepub/88-003-XIE/88-003-XIE03001.pdf

Statistics Canada, Service Bulletin Science Statistics, Vol 27, No.1 (February 2003). 
Table 3. Federal government biotechnology R\&D expenditure by selected departments or agencies and by performer, 2001-02 (millions USD PPP)

\begin{tabular}{|c|c|c|c|c|c|c|}
\hline & Intramural & $\begin{array}{l}\text { Business } \\
\text { enterprise }\end{array}$ & $\begin{array}{c}\text { Higher } \\
\text { education }\end{array}$ & $\begin{array}{c}\text { Foreign } \\
\text { performers }\end{array}$ & Other & Total \\
\hline $\begin{array}{l}\text { Agriculture and Agri-Food } \\
\text { Canada }\end{array}$ & 53.3 & 0 & 0 & 0 & 0 & 53.3 \\
\hline $\begin{array}{l}\text { Canadian Institutes of Health } \\
\text { Research }\end{array}$ & 9.7 & 0 & 95.6 & 2.6 & 36.2 & 144.1 \\
\hline Environment & 0.5 & 0.5 & 0.1 & 0 & 0 & 1.1 \\
\hline Fisheries and Oceans & 2.2 & 0.0 & 0.0 & 0 & 0.2 & 2.4 \\
\hline Genome Canada & 0.7 & 0 & 0 & 0 & 27.8 & 28.6 \\
\hline Health Canada & 4.2 & 0 & 0 & 0 & 0 & 4.2 \\
\hline Industry Canada & 0 & 24.9 & 0 & 0 & 0 & 24.9 \\
\hline National Research Council & 105.1 & 1.7 & 0 & 0 & 0.8 & 107.6 \\
\hline Natural Resources & 7.0 & 0.1 & 0.4 & 0 & 0 & 7.5 \\
\hline $\begin{array}{l}\text { Natural Sciences and Engineering } \\
\text { Research Council }\end{array}$ & 1.9 & 0.3 & 32.8 & 0.5 & 0.6 & 36.1 \\
\hline $\begin{array}{l}\text { Social Sciences and Humanities } \\
\text { Research Council }\end{array}$ & 0.1 & 0 & 1.4 & 0.1 & 0.2 & 1.9 \\
\hline Total & 184.7 & 27.4 & 130.4 & 3.2 & 65.9 & 411.7 \\
\hline
\end{tabular}

Source: OECD calculations based on Services Bulletin Science Statistics, Vol. 27 No 1, Statistics Canada, 2003.

Table 4. Federal government biotechnology R\&D expenditure and personnel by selected departments or agencies, 2001-2002 (millions USD PPP)

\begin{tabular}{|c|c|c|c|c|}
\hline & $\begin{array}{l}\text { Biotechnology } \\
\text { R\&D }\end{array}$ & $\begin{array}{l}\text { Total } \\
\text { R\&D }\end{array}$ & $\begin{array}{c}\text { Biotechnology } \\
\text { R\&D } \\
\text { (\% total R\&D) }\end{array}$ & $\begin{array}{c}\text { Biotechnology } \\
\text { R\&D person } \\
\text { years }\end{array}$ \\
\hline Agriculture and Agri-Food Canada & 53.3 & 288.9 & 18.4 & 400 \\
\hline Canadian Institutes of Health Research & 144.1 & 421.2 & 34.2 & 65 \\
\hline Environment & 1.1 & 178.3 & 0.6 & 5 \\
\hline Fisheries and Oceans & 2.4 & 102.6 & 2.4 & 11 \\
\hline Genome Canada & 28.6 & 28.6 & 100 & 22 \\
\hline Health Canada & 4.2 & 49.1 & 8.5 & 37 \\
\hline Industry Canada & 24.9 & 297.4 & 8.4 & 1 \\
\hline National Research Council & 107.6 & 539.6 & 19.9 & 796 \\
\hline Natural Resources & 7.5 & 319.6 & 2.3 & 76 \\
\hline $\begin{array}{l}\text { Natural Sciences and Engineering } \\
\text { Research Council }\end{array}$ & 36.1 & 459.0 & 7.9 & 19 \\
\hline $\begin{array}{l}\text { Social Sciences and Humanities } \\
\text { Research Council }\end{array}$ & 1.9 & 105.9 & 1.8 & 1 \\
\hline Other & na & 111.0 & n.a & n.a \\
\hline Total & 411.7 & 3900.5 & 10.6 & 1433 \\
\hline
\end{tabular}

Notes: "Other" includes Canadian non-profit institutions and provincial and municipal governments.

na $=$ not available

Source: OECD calculations based on Services Bulletin Science Statistics, Vol. 27 No 1, Statistics Canada, 2003. 


\section{Denmark}

The Danish biotechnology industry has been developed predominantly by small biotechnology firms with strong links to the scientific community. Alliances and collaborative arrangements are therefore especially important to biotechnology companies (Danish Institute for Studies in Research and Research Policy).

\section{Personnel}

The number of full-time equivalent (FTE) biotechnology researchers has increased faster in business enterprises than in the public sector. FTE biotechnology researchers in business enterprises increased by $13 \%$ per annum on average. By comparison, public sector FTE biotechnology researchers increased by $7 \%$ per annum for the period from 1989 to 1999 . Business enterprise and public sector FTE biotechnology researchers totalled 5804 in 2001, a decrease from 1999 when they numbered 7315 (Danish Institute for Studies in Research and Research Policy).

In 1999 there were just fewer than 16000 biotechnology employees involved in the production of medical products (International Benchmarking Medico/Sundhedsomradet i Danmark).

\section{Research and development}

Biotechnology and Information Communication Technology R\&D each account for about one quarter of Danish companies' R\&D expenditure. While the share of ICT in R\&D has remained at a relatively constant level from 1987 to 1999, the share of biotechnology in R\&D has increased from 9\% in 1987 to $26 \%$ in 1999. If the historical trend continues, biotechnology R\&D is set to become the leading area of $\mathrm{R} \& \mathrm{D}$ expenditure.

For R\&D-active companies, the share of companies performing biotechnology $R \& D$ has been stable up to 1995. Since then it has declined slightly. When this information is combined with the information about biotechnology R\&D shares it suggests that some specialisation may be occurring. Fewer companies are conducting biotechnology $R \& D$ but those companies which are conducting biotechnology $R \& D$ are focusing more on biotechnology (Danish Institute for Studies in Research and Research Policy).

The share of companies performing biotechnology R\&D has hovered about the 5\% mark from 1987 to 1999 (1997 shares are not comparable with shares for other years). Biotechnology companies generally have higher levels of co-operation with universities and other organisations in the world than non-biotechnology companies.

\section{Public perceptions}

Expectations of biotechnology depend on the scientific area of interest. The Danish public is most supportive of biotechnology used in medical research and development. For the five areas of "modern" biotechnology that were surveyed, medical R\&D, environment and genetically modified food received more support than opposition. Support and opposition were equally divided with respect to cloning. In comparison the public perception of biotechnology in terms of ethical/philosophical questions is more negative than positive, with one in five people opposing compared to one in ten supporting biotechnology in terms of ethical/philosophical questions (Danish Institute for Studies in Research and Research Policy). 
Figure 23. Danish public perceptions of modern biotechnology areas, 2000

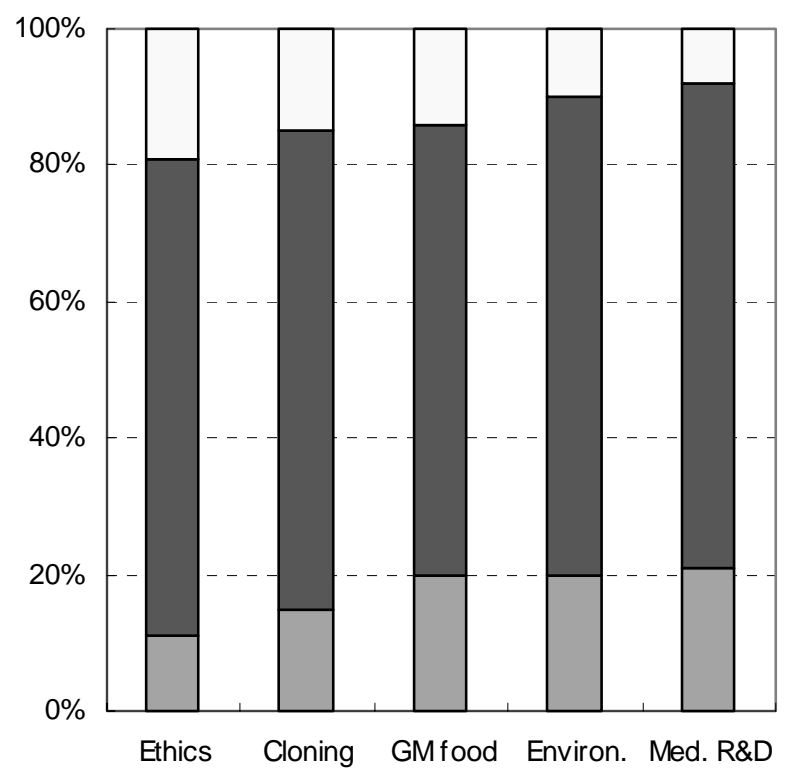

$\square$ Support $\quad \square$ Neutral $\quad \square$ Opposition

Figure 25. Distribution of $R \& D$ active companies in selected areas, 1987-1999

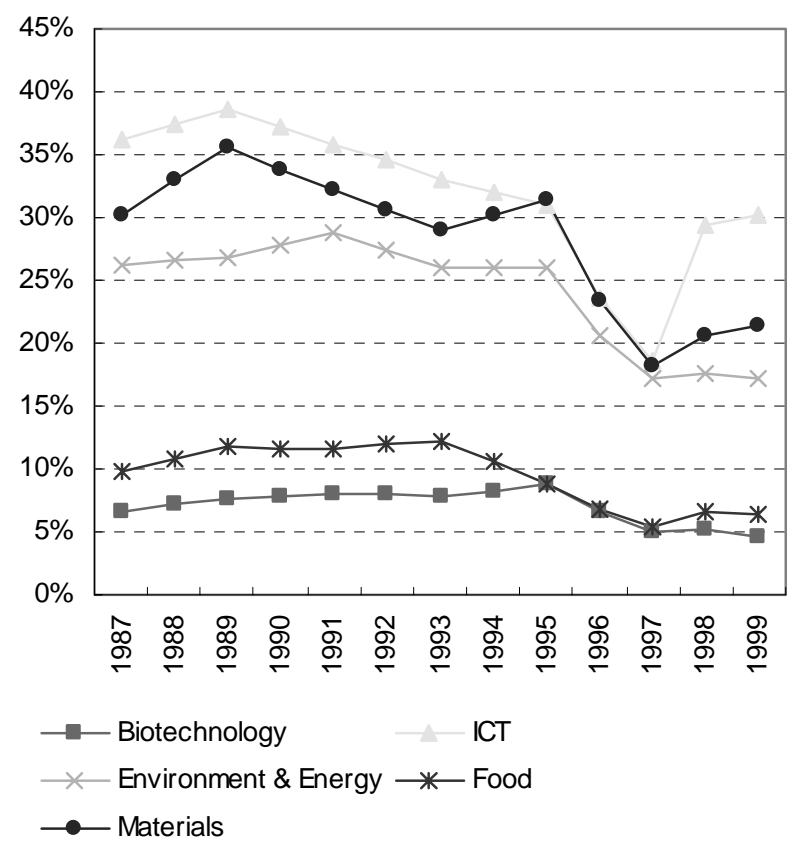

Figure 24. Full-time equivalent biotechnology researchers, 1989-1999

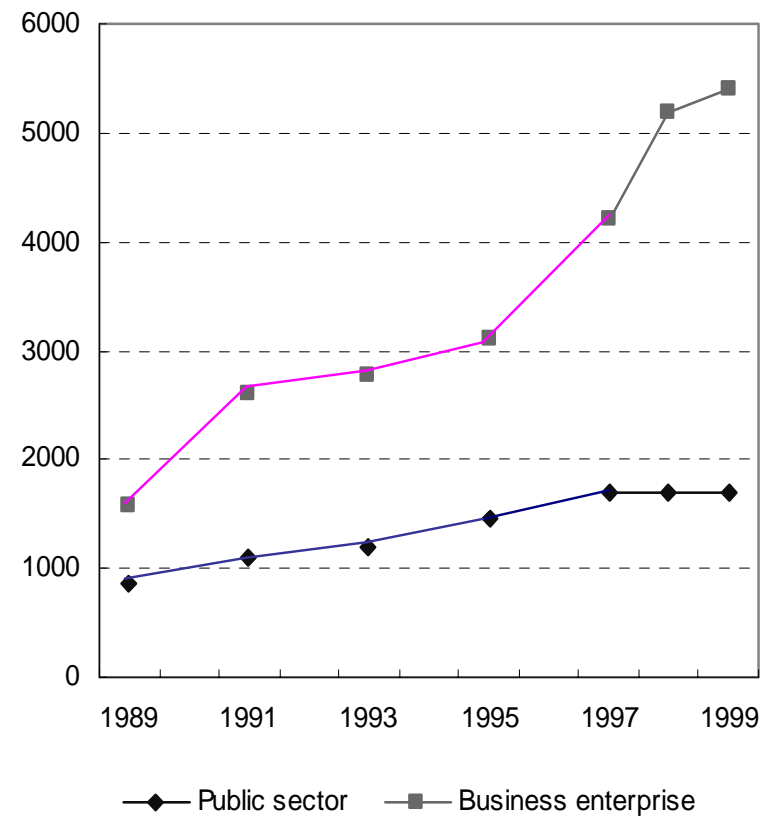

Figure 26. Share of Danish business R\&D expenditure in selected areas, 1987-1999

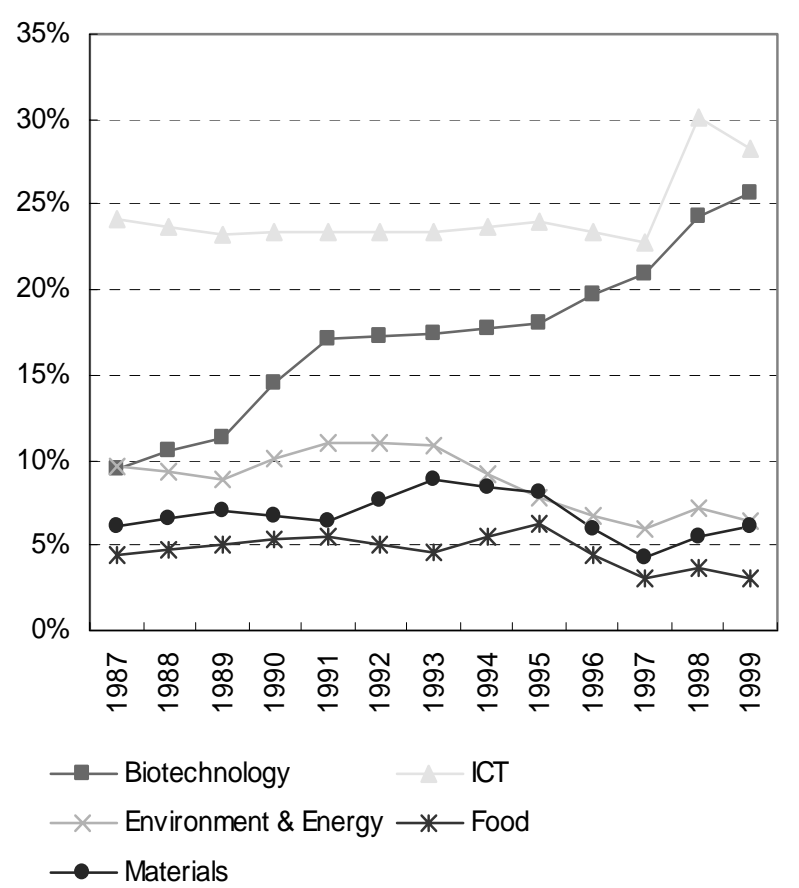

Source: Focus on Biotechnology. "Issues related to R\&D in biotechnology - Denmark in a comparative perspective". Danish Institute for Studies in Research and Research Policy, 2002/2. 


\section{Funding}

Government intramural R\&D funding for 2000 amounted to DKK 1024 million (Forskningsstatistikken). This is approximately USD 123 million (PPP adjusted).

The share of public biotechnology $R \& D$ in total public R\&D (gross domestic expenditure on research and development - GERD) has been steadily increasing from 1989 until 1997 but declined in 1999 to a level equivalent to that experienced in 1995 (Danish Institute for Studies in Research and Research Policy).

\section{Sources}

Danish Institute for Studies in Research and Research Policy, (2002/2). Focus on biotechnology. "Issues Related to R\&D in Biotechnology - Denmark in a Comparative Perspective" (a compilation of papers by various authors).

Forskningsstatistikken, February 2003.

International Benchmarking Medico/Sundhedsomradet i Danmark, September 2002, from Web site: http://www.ebst.dk/download/pdf/benchmarking.pdf (in Danish). 


\section{Finland}

\section{Personnel}

Biotechnology is a new area, and that is reflected in the size of the biotechnology firms. Newer firms will have fewer employees than longer established ones. Based on survey responses from 84 Finnish biotechnology companies, approximately half of all biotechnology firms founded prior to 1991 have more than 250 employees. By comparison, approximately $60 \%$ of biotechnology firms founded after 1991 have fewer than 10 employees (ETLA).

Approximately two out of three people employed in a biotechnology firm are employed in the pharmaceutical sector. This is because three big pharmaceutical firms employ about $60 \%$ of all biotechnology employees (Biotech Finland).

\section{Industrial sectors of activity for biotechnology firms}

When considering the numbers of biotechnology companies, diagnostic and service companies represented just under half of all Finnish biotechnology firms in 2000. If the three big pharmaceutical companies are excluded, approximately three quarters of turnover from biotechnology firms are from firms involved in the diagnostics and food and feed sectors (Biotech Finland).

The industrial sector of activity for Finnish biotechnology firms has changed from those firms founded before 1996 to firms founded after 1996. Every second biotechnology firm founded before 1996 is involved in diagnostics. More recently biotechnology firms have become involved in the pharmaceutical sector (Hermans \& Luukkonen).

\section{Research and development}

Statistics Finland reports that biotechnology R\&D in 2000 totalled EUR 24.1 million, equivalent to about $4.8 \%$ of total public sector R\&D. In the higher education sector, biotechnology research was about $11.5 \%$ of total higher education sector R\&D (Statistics Finland).

\section{Start-up difficulties}

Difficulties in establishing a biotechnology firm have changed over the past ten years. New entrants in 1991-96 stated their four leading difficulties were funding, underdeveloped business ideas, insufficient business experience and scarcity of skilled labour. By comparison, new entrants in 1997-2001 stated their four leading difficulties as funding, insufficient business experience, underdeveloped business ideas and intellectual property rights. Scarcity of skilled labour is apparently no longer an issue and has been replaced by difficulties relating to intellectual property rights (Hermans \& Luukkonen). 
Figure 27. Size of biotechnology firms by foundation date

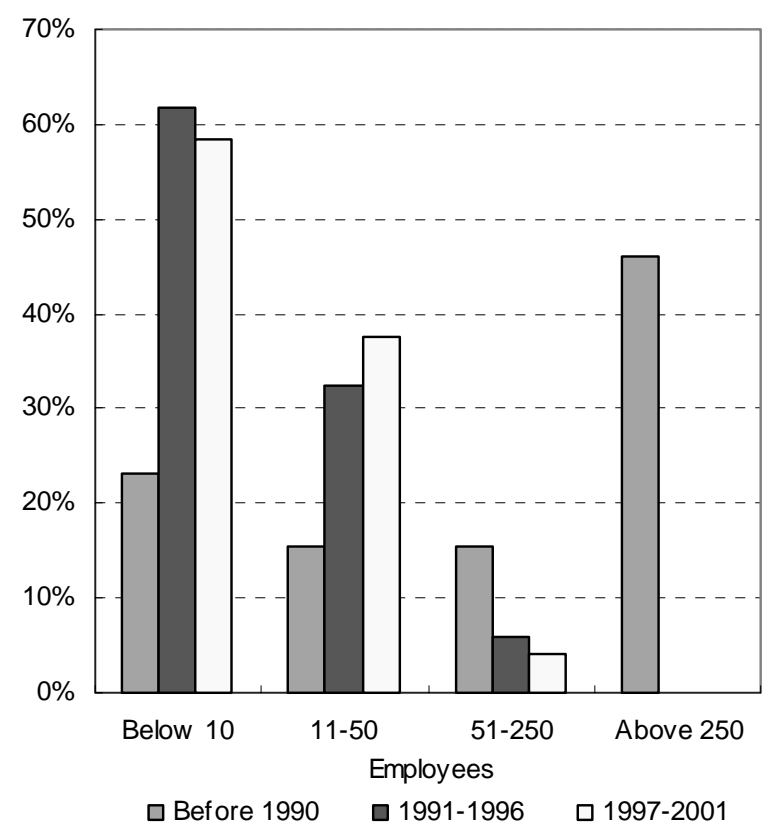

Figure 29. Number of companies by sector, 2000

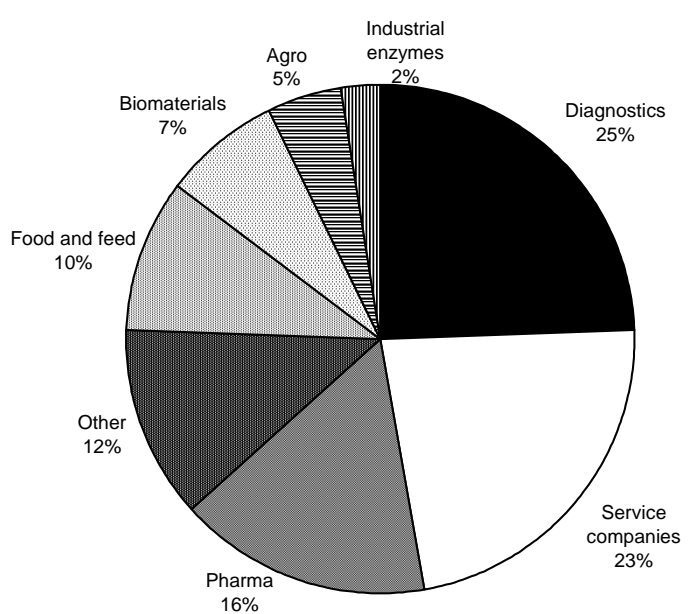

Figure 28. Personnel in biotechnology firms, 2000

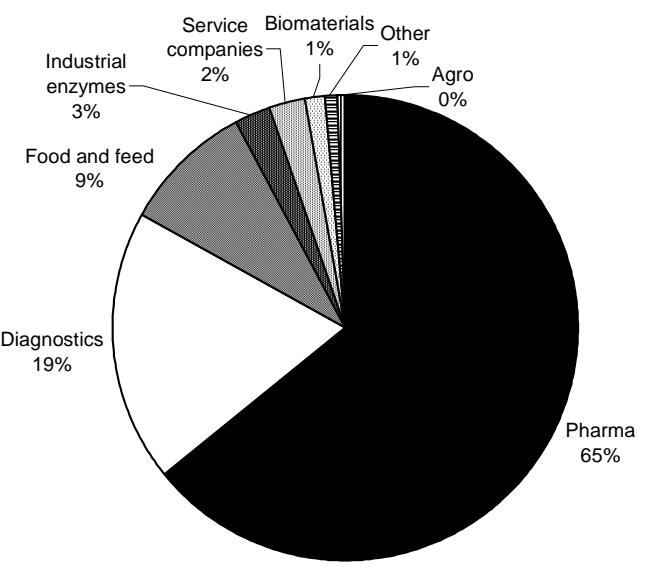

Figure 30. Relative areas of interest for biotechnology firms by firm foundation date

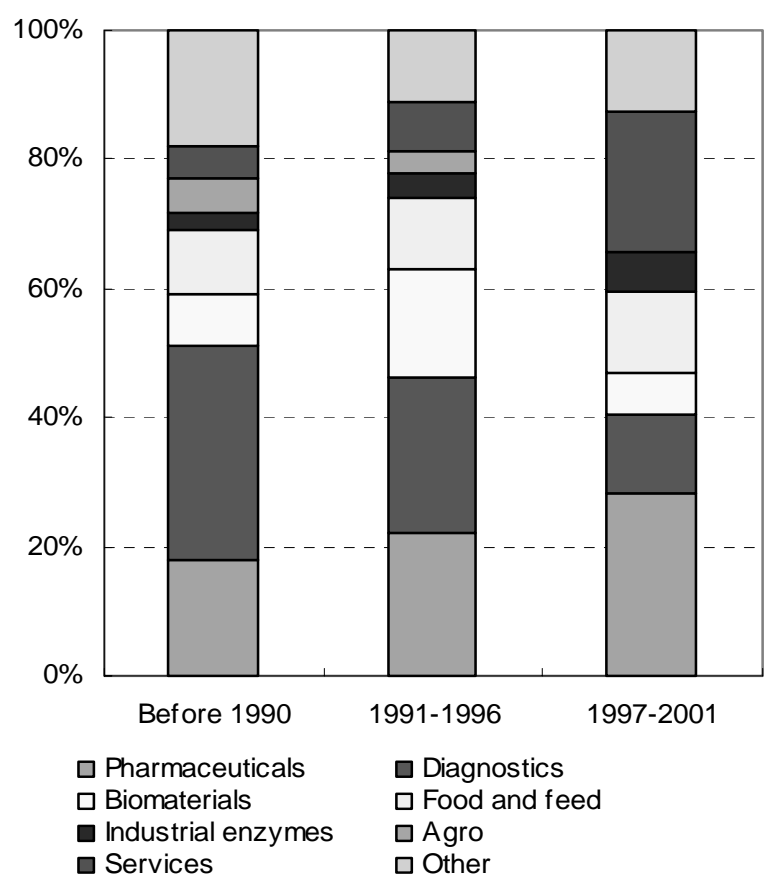

Source: Hermans \& Luukkonen (2002), Findings of the ETLA survey on Finnish Biotechnology firms, No. 819, September 2002 and Finnish Bioindustries, January 2002. 
Figure 31. Relative importance of difficulties in start-up by firm foundation date

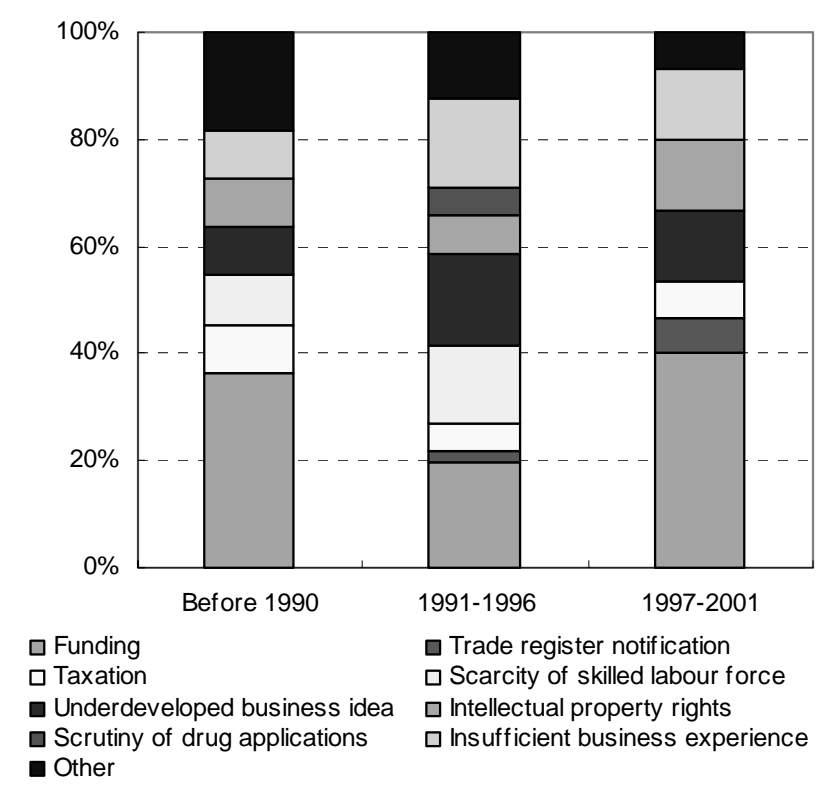

Source: Hermans \& Luukkonen (2002), Findings of the ETLA survey on Finnish Biotechnology firms, No. 819, September 2002.

\section{Funding}

Several different government agencies are responsible for public funding of biotechnology. The Ministry of Trade and Industry funds the national technical agency (TEKES) and the technical research centre of Finland (VTT). The Ministry of Trade and Industry allocated EUR 46.6 million to biotechnology in 2001. The Ministry of Education is responsible for funding academic institutions for R\&D. Total university research funds allocated to biotechnology research by this government ministry amounted to an estimated EUR 28.2 million in 2001. The Ministry of Social Affairs and Health directly funds its own research institutes. In 2001, the Ministry of Social Affairs and Health dedicated EUR 4.8 million to its two institutes for biotechnology research. The Ministry of Agriculture and Forestry does not provide funding for biotechnology but does fund peer-reviewed biotechnology research projects. In 2001 this was estimated to be EUR 412 000. The Ministry of Environment's biotechnology R\&D funding was about EUR 30000 in 2001. Another EUR 42000 was allocated to universities and research institutes for biotechnology research projects. Thus Finland's public funding for 2001 is estimated to be about EUR 81 million.

\section{Brief policy overview}

Finland's commitment to biotechnology is reflected in the top political echelons. The government established the Science and Technology Policy Council in March 1987. This council is currently chaired by the prime minister. In 2002, the Academy of Finland published a paper suggesting future biotechnology strategies. According to this report, biotechnology is the second priority area in Finland after ICT.

TEKES is the main financing organisation for applied and industrial R\&D in Finland. One-third of TEKES' annual budget - EUR 390 million - is channelled into life science research. Funding is granted from the state budget. 
The Finnish government supports several biotechnology research programmes. Drug 2000 is the programme attracting the largest amount of public funding. This programme, which has a budget for 2001 to 2006 of EUR 110 million, focuses on biomedicine, drug development and pharmaceutical technology. The objectives of this programme are to promote Finnish drug development, create and improve new and existing research networks, boost the competitiveness of research service units and enterprises and to generate new international business operations in the pharmaceutical sector.

In the "Impact of Public Research Funding and Strategies for the Future" report, approximately 50\% of biotechnology R\&D in Finnish firms is attributed to chemicals, including pharmaceuticals. Finnish biotechnology companies are predominantly involved in the pharmaceutical industry, with the significant majority of turnover and personnel in biotechnology found in that industry.

\section{Sources}

Academy of Finland (November 2002). Biotechnology in Finland; Impact of public research funding and strategies for the future; Evaluation report.

Finnish Bioindustries (January 2002). Biotech Finland.

Hermans, R \& Luukkonen, T (2002). Findings of the ETLA Survey on Finnish Biotechnology Firms, discussion paper No 819.

Statistics Finland (2002). "Biotechnology in Figures" brochure. 


\section{France}

\section{Enterprises}

According to the Ministry of Research Web site (http://www.recherche.gouv.fr) almost two-thirds of the more than 300 biotechnology enterprises that exist in France are involved in the health sector. There are also many biotechnology enterprises involved in the agri-foodstuffs and the environment (especially marine environment) sectors. Biotechnology enterprises are often created by a scientist, are small with fewer than 50 employees and created less than six years ago.

As biotechnology is a relatively new field, it attracts many start-ups. In France there have been several waves of biotechnology firm creations. The first wave occurred in the early 1980s and peaked in 1986 with the creation of 15 firms. Between 1988 and 1995 there was a second and much larger wave peaking in 1990 and 1991 with the creation of 27 new biotechnology firms each year. The third wave has resulted in close to 70 biotechnology enterprises being created in 2000 .

Biotechnology cuts across many disciplines. Many biotechnology firms conduct R\&D as their primary activity. These firms are either group subsidies or start-ups and often not in a position to generate substantial turnover.

Table 5. Activities of biotechnology enterprises with fewer than 500 employees, 2001

\begin{tabular}{|l|cc|}
\hline & Share of enterprises & $\begin{array}{c}\text { Share of } \\
\text { employees }\end{array}$ \\
\hline Research and development & $37 \%$ & $21 \%$ \\
Engineering and technical studies & $16 \%$ & $11 \%$ \\
Pharmaceuticals, fragrance and cleaning/maintenance materials & $10 \%$ & $18 \%$ \\
Agri-food industries & $6 \%$ & $19 \%$ \\
Chemicals, rubber, plastics & $6 \%$ & $9 \%$ \\
Other & $25 \%$ & $22 \%$ \\
\hline Source: Lhuillery, S. (2003). "Biotechnology Firms in France in 2001", paper presented to the 4" Ad Hoc NESTI Meeting on \\
Biotechnology Statistics, OECD, Paris, May 2003.
\end{tabular}

\section{Field of research and development}

In 2000, the share of R\&D expenditure that businesses devoted to biotechnology was estimated to be 5\%. Biotechnology R\&D is especially focused on medicine or medical-related activities. Medical biotechnology areas of research cover:

- Human diseases and genetic predisposition towards certain diseases such as cancer, cardiovascular disease and degenerative neurological diseases.

- Genetic predisposition towards pharmaceutical drug resistance.

- Individually tailored pharmaceutical drugs.

- Genetic therapy (modifying cellular genetics).

- Cellular therapy. 


\section{Personnel}

According to results from the 2002 biotechnology survey, in 2001 some 125000 people were employed in biotechnology; one quarter of biotechnology employees were employed in enterprises with fewer than 500 employees. Independent firms developing products with fewer than 500 employees assigned some 2500 people to $R \& D$ which is 2.5 times as many employees as support firms with fewer than 500 employees.

\section{Funding}

One of the areas of interest for the French government is research in genomics. Since the GenHomme network's creation in June 2000, the government has devoted EUR 25 to 30 million annually to finance 30 to 40 projects. Equal amounts are contributed by the Ministry of Research and the Ministry of Economy, Finance and Industry. This project attracts a total of EUR 300 million over five years contributed in equal parts by the government and the private sector.

\section{Brief policy overview}

The Ministry of Research Web page (www.recherche.gouv.fr) reports a key project in 2003 is research into therapeutic innovations and diagnostics for human health. This project is aimed at detection of transmissible and non-transmissible diseases, including very rare diseases and those which represent a bio-terrorist threat. Individual projects should meet one of the three main objectives:

- Reduce the cost, duration and development of active molecules, therapeutic or prophylactic vaccines, new markers or diagnostic/prognostic tests as well as the rapid detection of them.

- Increase the chances of success of marketing diagnostic tests or a therapeutic product - especially in the case of infectious diseases and intoxications related to bio-terrorist risks.

- Reduce the costs of health treatment and expenditure.

France is also proposing a strategy to encourage young innovating enterprises. Young enterprises less than eight years of age having a ratio of $R \& D$ expenditure to total expenditure of more than $15 \%$ on average can benefit from the following tax incentives:

- An exemption of society tax for the first three years that the enterprise makes a profit and then a $50 \%$ reduction for the two following years.

- An exemption from paying employer taxes for six years and then a 50\% reduction for four years.

- An exemption from paying local taxes.

- Investors and shareholders who keep the shares for more than three years will be exempted from capital gains tax.

\section{Sources}

Ministry of Research Web site (www.recherche.gouv.fr)

Lhuillery, S. (2003). "Biotechnology Firms in France in 2001", paper presented to the 4th Ad Hoc NESTI Meeting on Biotechnology Statistics, OECD, Paris, May 2003. 


\section{Germany}

\section{Personnel}

In 2001-02, the German Federal Statistical Office conducted a voluntary survey of enterprises performing activities in the biotechnology field. The year of reference was 2000. The Federal Statistical Office used the OECD list-based definition (see background and introduction).

Based on survey responses from 666 enterprises, the Federal Statistical Office concluded that there are 18839 people employed in biotechnology (core enterprises and big life sciences companies). Furthermore 9906 people were employed in "core biotechnology enterprises", of which the majority of enterprises had fewer than 50 employees.

\section{Turnover}

The German Federal Statistical Office estimates that there are between 500 and 550 core biotechnology enterprises that work with mainly modern biotechnological procedures. The 313 core biotechnology enterprises which provided information in the survey reported turnover per employee of just under EUR 60 000. However, it is especially the larger businesses of the life sciences industry that contribute much to the economic importance of biotechnology in Germany. The 24 big enterprises in life sciences who responded reported a turnover (with biotechnological products) per biotechnology employee of EUR 387000.

Large enterprises in the life sciences industry reported a total turnover (with biotechnological products) of about EUR 3.5 billion in 2000. Core biotechnology enterprises reported a total turnover of EUR 594 million.

\section{Funding}

EUROSTAT's NewCRONOS database, which reports on government budgetary allocations or outlays to R\&D, shows that German biotechnology GBAORD was EUR 501.625 million in 2000. This figure reflects all public R\&D expenses associated with biotechnology.

The official report Faktenbericht Forschung 2002 of the Federal Ministry of Education and Research (BMBF) reported that the German federal government allocated EUR 261.3 million to biotechnology research funding in 2000. This compares with EUR 246 million for each of 1998 and 1999 and EUR 324 million for 2001.

In Germany, both the federal and local governments (Länder) contribute to R\&D expenditure. Unfortunately no information is available on $\mathrm{R} \& \mathrm{D}$ expenditure by Länder, which means that German biotechnology funding will be more than the federal figures presented above, as expenditure by the Länder is thought to be significant.

\section{Brief policy overview}

Biotechnology is a "key technology" for the German government - both at the federal and Länder level. General policy goals are to promote basic research as well as high level research efforts in the environment, health, nutrition, energy and raw materials supplies, to improve the research infrastructure (particularly the framework conditions for research and development in industry), to foster investigations on safety and ethical issues and to strengthen technology transfer and commercialisation, e.g. by supporting SMEs (EBIS). 
The "Biotechnology 2000" programme covered the period from 1990 to 2000. The programme's aim was to strengthen the process from invention to innovation and to extend the scientific base. Programme activities centred on the human health and environment areas.

The Faktenbericht Forschung 2002 report indicates that EUR 179 million will be spent on the National Genome Research Network from 2001-2003. The National Genome Research Network will fund research in five areas of disease and disorders that affect large numbers of people. As well as funding human health research, the National Genome Research Network will integrate ethical, social and legal issues of genome research.

The federal government also allocated in both 2001 and 2002 approximately EUR 150 million to "Biotechnology - Using and Shaping the Opportunities", a programme that supports innovation in biotechnology and genetic engineering as well as funding genome research and supporting reorganisation on industrial processes with the help of biotechnological methods to make them more sustainable (Federal Ministry of Education and Research).

The European Biotechnology Innovation Systems (EBIS) report that the German public's general perception of biotechnology is sceptical, especially with respect to genetic engineering approaches in agriculture and food processing. The German government has sought to address some of these fears through public education, of which an example includes a programme to enable school pupils to consciously cope with new technologies in general and with modern biotechnology in particular.

\section{Sources}

Eurostat, NewCRONOS database.

Federal Ministry of Education and Research (BMBF). Faktenbericht Forschung 2002.

Wörner et al. (July 2000). European Biotechnology Innovation Systems (EBIS), "Case Studies: Germany". 
Figure 32. Employees in biotechnology enterprises, 2000

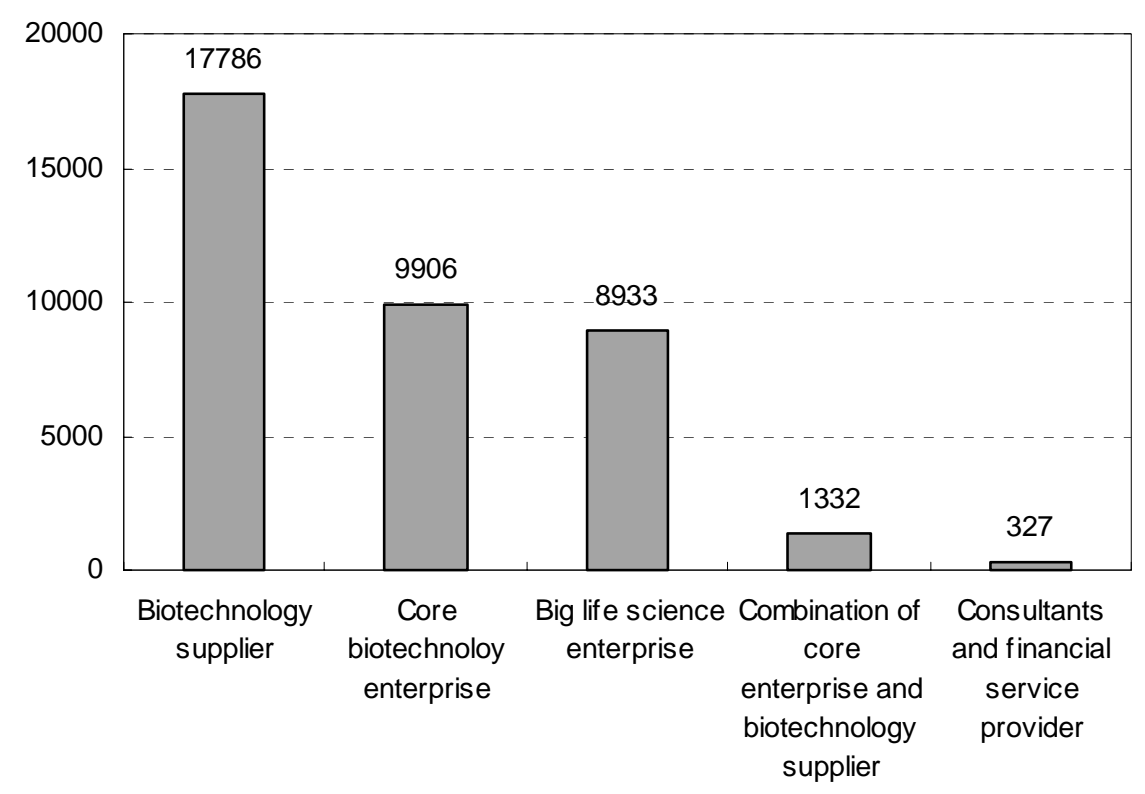

Figure 33. Turnover per biotechnology employee

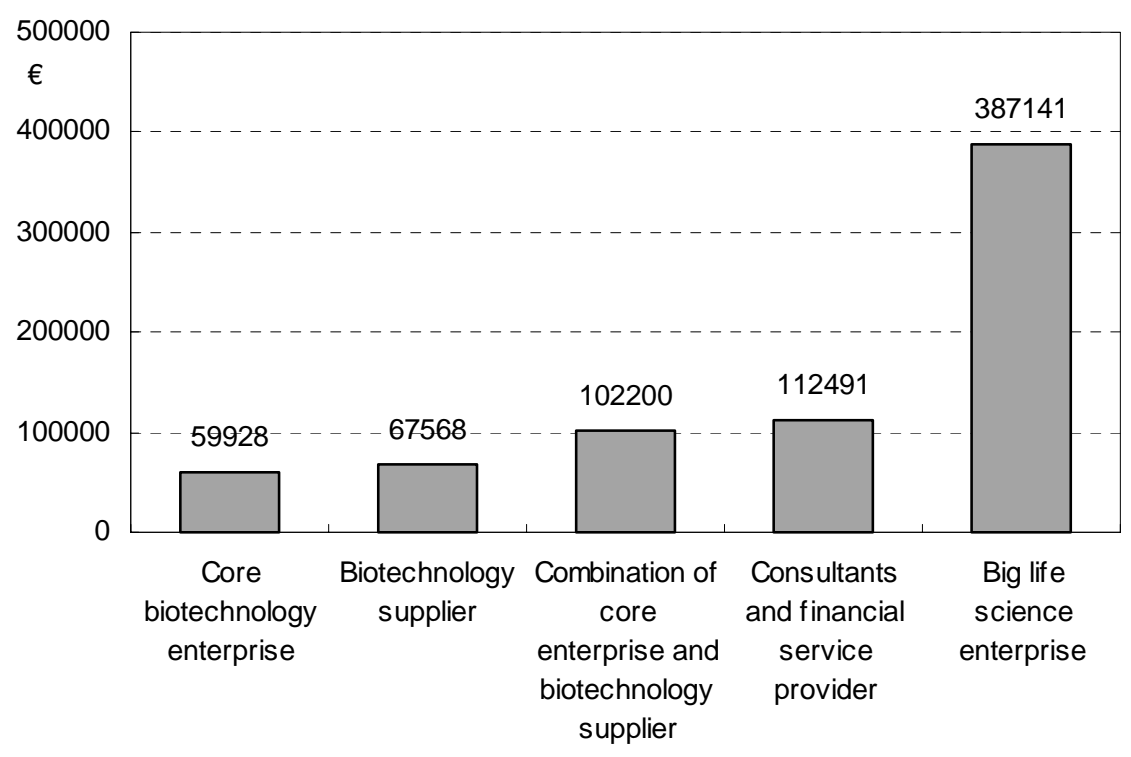

For a definition of biotechnology enterprise classifications, refer to Unternehmen der Biotechnologie in Deutschland, "Ergebnisse einer Pilotstudie für das Jahr 2000" (in German).

Source: German Federal Statistical Office. 


\section{Greece}

Funding

Biotechnology is a national priority of Greek R\&D policy. Final government budgetary appropriations on biotechnology R\&D for 2001 were EUR 42.6 million, representing about $10 \%$ of the total government budget appropriations to R\&D. Approximately $60 \%$ of biotechnology government R\&D funding in 2001 was allocated to Nomenclature for the Analysis and Comparison of Scientific Programmes and Budgets (NABS) codes 04 and 06 . These two codes refer to protection and improvement of human health and to agricultural production and technology respectively. Human health accounted for $28 \%$. In particular, biomedical engineering and medicines attracted EUR 6 million of the EUR 12 million allocated to human health. Similar patterns are expected for 2002 using the provisional data that are available.

Biotechnology R\&D data are potentially underestimated due to absence of data for research financed from general university funds (NABS 10). Using data available from other OECD countries research financed from general university funds accounts for an average of about $33 \%$ of total GBAORD allocations. Note that this is total R\&D and not biotechnology specific R\&D funding.

\section{Source}

Government Budgetary Appropriations on R\&D Survey Results, April 2003. General Secretariat for Research and Technology. 


\section{Iceland}

\section{Enterprises}

Rannís (Icelandic Research Centre) reported that in 2001 biotechnology enterprises in the business sector had a turnover of ISK 11 billion. Furthermore there were 919 biotechnology employees in the business sector. The majority of these biotechnology employees are employed by deCODE genetics, which is constructing an Icelandic Health Sector Database (Finnbjörnsson, 2001).

This nationwide database was started in January 2000 and will run for 12 years. It collects information in a coded and anonymous form from patient records from Iceland's National Health Service institutions and stores the data for the purpose of research and statistical analysis with the aim of increasing knowledge in order to improve health and health services. Data can be cross-referenced with the company's genealogical database.

\section{Funding}

In 2002, ISK 102 million were publicly allocated to biotechnology. This is about USD 1.1 million (PPP adjusted). Icelandic public funding for biotechnology comes from four different sources, of which approximately half comes from the European Union.

No information is available concerning the purpose of the public biotechnology funding mentioned above.

\section{Source}

Finnbjörnsson, T. (2001). $R \& D$ in the Field of Biotechnology in Iceland. Paper presented to the second ad hoc NESTI meeting on biotechnology statistics at the OECD, Paris.

Rannís (2003), Survey for Measuring Research and Development in Biotechnology. Contact:

Thorvald Finnbjörnsson, Rannís. 


\section{India}

\section{Revenue}

Total turnover in 1999 for the biotechnology industry amounted to INR 69349 million (approximately USD 8095 million PPP adjusted). Turnover has increased from 1997 to 1999 by 74\%, with biotechnology enterprises engaged in health experiencing the biggest increase. In comparison, enterprises engaged in the environment sector experienced a decrease in turnover from 1997 to 1999 by $26 \%$. Not only is turnover the highest for enterprises in health, but when the number of employees is considered, health enterprises have the highest turnover per employee: about USD 190000 (PPP adjusted). By comparison, agriculture turnover per employee is about USD 89000 PPP adjusted (Chaturvedi, 2002).

\section{Personnel}

Indian biotechnology employees are mainly employed in the health (47\%) and the agriculture (25\%) sectors (Chaturvedi, 2002). Technical employees in the health and agriculture sectors accounted for $31 \%$ and 19\% respectively of all technical employees in the biotechnology industry. Although the share of technical biotechnology employees in the health sector is small, enterprises in the medical sector make up $38 \%$ of biotechnology firms with foreign alliances. Only $36 \%$ of biotechnology enterprises engaged in the agriculture sector have foreign alliances.

Figure 34. Turnover of biotechnology enterprises, 1999

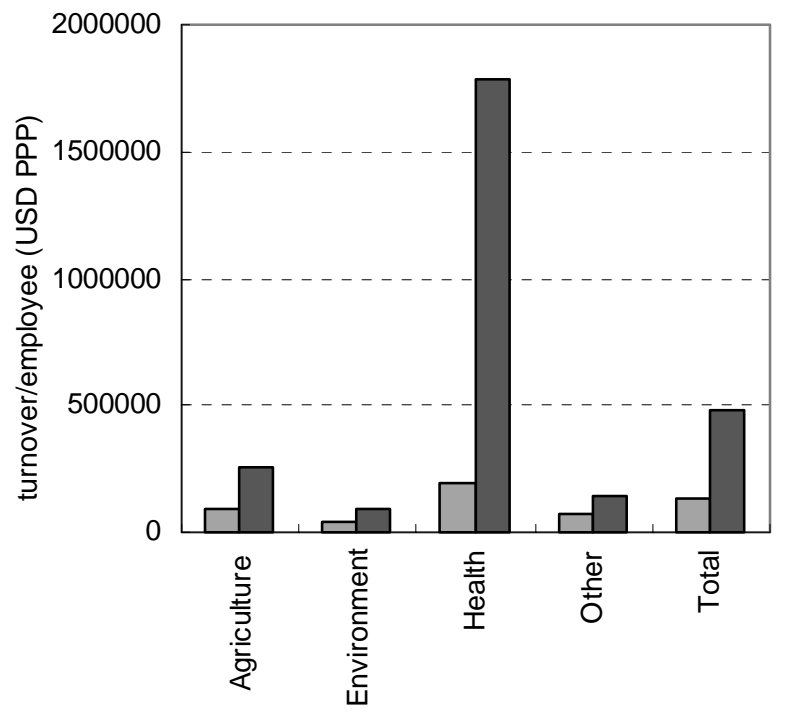

$\square$ total employees $\square$ technical employees
Figure 35. Share of technical staff in total staff in the biotechnology industry by field, 1999

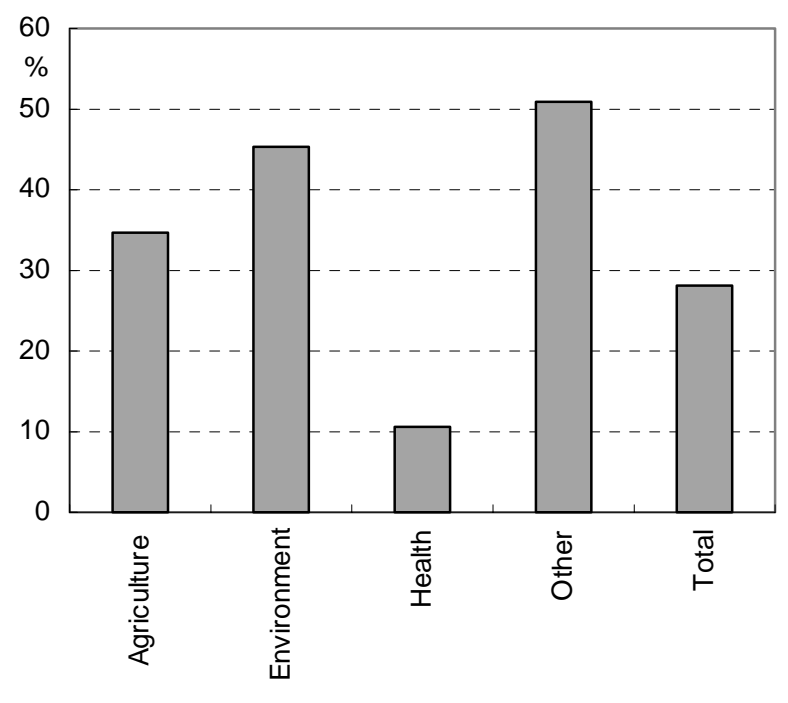

Table 6. Investment, employees and turnover of biotechnology firms, 1999

\begin{tabular}{|l|cccc|}
\hline Field & $\begin{array}{c}\text { Investment } \\
\text { (million USD PPP) }\end{array}$ & Total employees & Technical employees & $\begin{array}{c}\text { Turnover (million USD } \\
\text { PPP) 1999 }\end{array}$ \\
\hline Agriculture & 878.3 & 15029 & 5217 & 1341.1 \\
Environment & 2.3 & 66 & 30 & 2.8 \\
Health & 2067.7 & 28520 & 3066 & 5482.7 \\
Other & 99.1 & 16905 & 8619 & 1268.0 \\
Total & 3047.4 & 60520 & 16932 & 8094.6 \\
\hline
\end{tabular}

Source: OECD calculations based on data from the paper, "Collection of Biotechnology Statistics and Status of Biotechnology in India: An Analytical Overview", presented by Sachin Chaturvedi to the $3^{\text {rd }}$ NESTI Ad Hoc Meeting on Biotechnology Statistics, Finland, 2002. 


\section{Investment}

The health sector accounts for two-thirds of all biotechnology investment. Biotechnology enterprises in the agriculture sector account for just fewer than $30 \%$ of biotechnology investment. With a combination of high investment in health biotechnology investment and high turnover per employee in health, the health sector looks to be an area of strong biotechnology growth in India.

\section{Funding}

2002-03 budgetary allocations of the Department of Biotechnology amounted to INR 2356 million (about USD 240 million (PPP adjusted)). The Department of Biotechnology experienced an increase in funding from 1987-88 to 2002-03 with an average annual increase of $12.5 \%$. Increases in funding have been most pronounced in recent years, with 26\% reported for 2001-02 to 2002-03.

\section{Brief policy overview}

The Indian government provides the following incentives for investment in the biotechnology industry and R\&D:

- $100 \%$ foreign equity investment is possible in almost all sectors.

- $100 \%$ foreign equity investment is automatic in drugs and pharmaceuticals sector and over $74 \%$ is on case by case basis.

- $\quad$ Fast track clearance route for FDI.

- Depreciation allowance on plant and machinery set up based on indigenous technology.

- Customs duty exemption on goods imported for use in government-funded R\&D projects.

- Customs and excise duty exemptions to recognised scientific and industrial research organisations.

- $125 \%$ weighted tax deduction on R\&D expenditure.

- Three years excise duty waiver on patented products.

- $\quad 100 \%$ rebate on own $\mathrm{R} \& \mathrm{D}$ expenditure.

- $125 \%$ rebate if research is contracted in public funded R\&D institutions.

- Joint R\&D projects are provided with special fiscal benefits (Rao, 2002).

\section{Sources}

Chaturvedi, S. (2002). "Collection of Biotechnology Statistics and Status of Biotechnology in India: An Analytical Overview", paper presented to the $3^{\text {rd }}$ Ad Hoc NESTI Meeting on Biotechnology Statistics, Finland, 2002.

Rao S.R. (2002). "Indian Biotechnology Developments in Public and Private Sectors - Status and Opportunities", Asian Biotechnology and Development Review, Vol. 5, No. 1, November 2002. 


\section{Ireland}

\section{Research and development}

R\&D survey results for 2001 from 3500 companies surveyed indicated that the food and drink sector accounts for the largest share of Irish biotechnology R\&D (68\%) followed by the pharmaceutical sector with 26\%. The survey results indicate that biotechnology R\&D (EUR 13.01 million) represents $1.4 \%$ of business R\&D. Forfás (Ireland's National Policy and Advisory Board for Enterprise, Trade, Science, Technology and Innovation) believe this is an underestimate since the questionnaire did not include a definition of biotechnology, resulting in a highly variable interpretation of biotechnology.

Figure 36. Percentage share of biotechnology R\&D

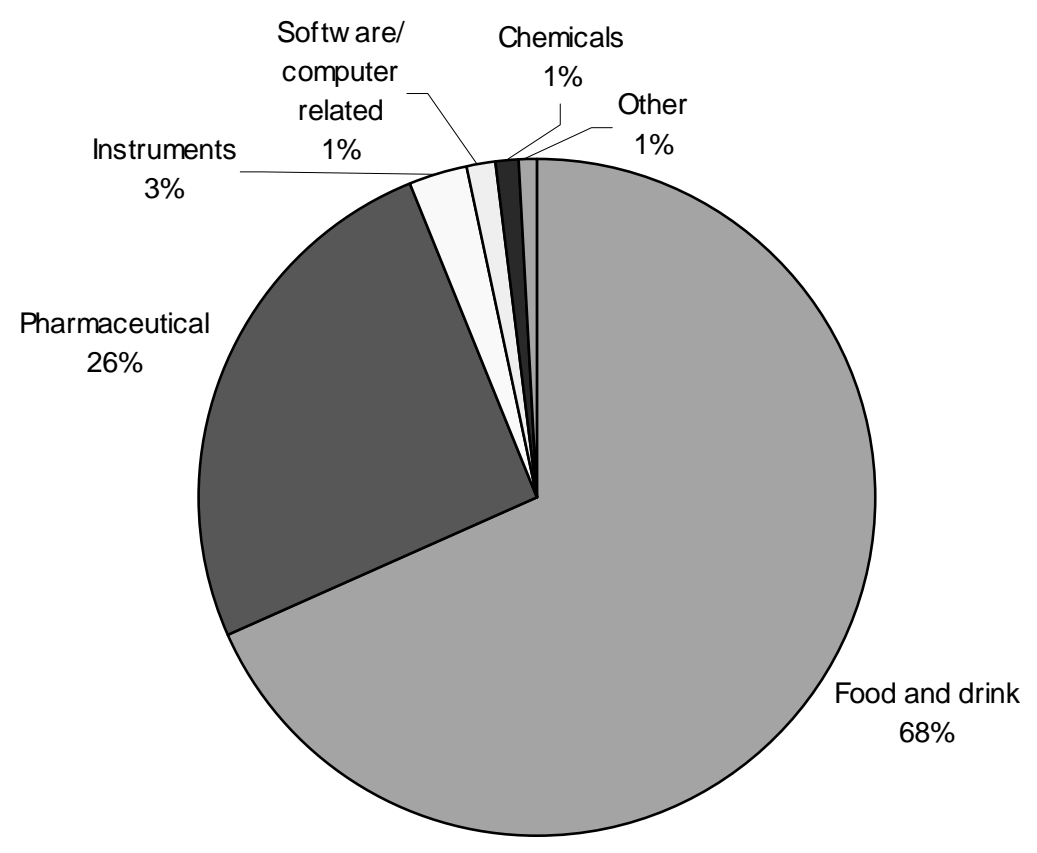

Source: Dempsey, R. (Forfás). Presentation to the $4^{\text {th }}$ Ad Hoc NESTI Meeting on Biotechnology Statistics, OECD, Paris, 2003.

\section{Funding}

EUROSTAT provides data on government budgetary allocations or outlays for R\&D. This data shows that Ireland allocated EUR 1.993 million to biotechnology in 2000.

\section{Brief policy overview}

The National Development Plan (2000-06) allocated EUR 2.5 billion to be spent on Research, Technological Development and Innovation (RTDI). A central strategic part of this plan was the establishment of the Science Foundation Ireland (SFI) in 2000 as a sub-board of Forfás. In February 2000 the government allocated EUR 635 million to the SFI as part of the National Development Plan. The SFI will focus initially on the information communication technology and biotechnology areas with the aim of promoting and encouraging "research of world-class status" (www.sfi.ie). In 2002 the Irish government established the SFI as a separate legal identity. 
The SFI supports research in the biological and other sciences, highlighting biotechnology including bioengineering. No sub-specialities are highlighted to avoid restricting the most creative potential investigator initiated proposals.

In March 1999, the government reacted to concerns about genetic modification and established the "Interdepartmental Group on Modern Biotechnology". This group comprises senior officials across government departments.

\section{Sources}

Dempsey, R., (Forfás) (2003). Presentation to the $4^{\text {th }}$ Ad Hoc NESTI Meeting on Biotechnology Statistics, OECD, Paris, 2003.

Inter-departmental Group on Modern Biotechnology Report, October 2000.

Science Foundation Ireland Web site www.sfi.ie, February 2003. 


\section{Israel}

\section{Enterprises}

According to the Ministry of Foreign Affairs Web site, there were about 160 biotechnology companies in Israel in 2000, with 25 new companies registering in 2000. In 1996, there were close to 90 biotechnology companies. The biotechnology industry employs 4000 people and sales reached USD 800 million (Israel's GDP is approximately USD 93 billion) with $80 \%$ of biotechnology products being exported.

Pharmaceuticals are Israel's main source of biotechnology sales, with the share of biotechnology pharmaceutical sales rising to over $70 \%$ in 2000. Teva Pharmaceutical Industries is Israel's leading drug company and one of the world's largest manufacturers of generic pharmaceuticals. The industry is also experiencing an influx of second-generation entrepreneurs from the software and telecommunication industries.

\section{Brief policy overview}

Biotechnology is mentioned on the Ministry of Foreign Affairs Web site as being "an increasingly important part of the government's aid programmes". As a policy to encourage R\&D, companies can apply to the Office of the Chief Scientist (OCS) for funding to cover R\&D costs. Companies are only liable to repay the loan if the project leads to a commercially successful product. In 1990 the National Biotechnology Committee was founded to promote biotechnology research and entrepreneurial activities and to advise the government on industry development. The largest and most important programme of the OCS is sponsorship of the development of novel generic technologies. This programme underwrites up to $65 \%$ of companies budgets which develop novel generic technologies.

The Ministry of Industry and Trade also gives grants and incentives for capital spending on plant and equipment through its investment centre. From 2002-07, the Ministry of Science, Culture and Sports recognises biotechnology as a "national project" and allows at least ten different research groups to train people, strengthen research infrastructure and to allocate funds for academic biotechnology and medical research.

\section{Sources}

Ministry of Foreign Affairs Web site: http://www.mfa.gov.il/mfa/home.asp 


\section{Italy}

\section{Funding}

EUROSTAT's NewCRONOS database shows that GBAORD (government budgetary appropriations or outlays on R\&D) associated with biotechnology were EUR 56 million for Italy in 2000.

The National Research Council (NCR) funds publicly funded research in biotechnology. Total funding for their second target project on biotechnology, which ran from 1998 to 2002, amounted to ITL 87 billion (about USD 45 million).

\section{Brief policy overview}

The main area of research interest for the NCR in their second target project on biotechnology was biomedicine which accounted for 58\% of biotechnology funding. The areas within biomedicine with special biotechnology interest are cancer research, pre-natal diagnosis and organ transplant rejection. Other areas of interest attracting biotechnology funding in the second target project are food, agriculture, environment and the industrial sector.

\section{Sources}

EUROSTAT, NewCRONOS database.

National Research Council, www.ncr.it/ (in Italian). 
Japan

\section{Venture capital}

Biotechnology is an industry in Japan which has historically received a relatively small share of venture capital investment. From 1990-94 there was no venture capital investment in biotechnology. Since then this has changed, with 1995-99 recording JPY 152 million in real terms which is equal to $2.1 \%$ of total venture capital investment. In 2000, biotechnology venture capital investment represented $4.7 \%$ of venture capital. Just under half of all venture capital in 2000 was allocated to three areas: business services (16\%), Internet-related (14.4\%) and computer-related (13.8\%).

\section{Funding}

Government funding of biotechnology comes from five government departments. According to the fiscal 2002 government budget, in 2001 the government budget related to biotechnology amounted to:

- JPY 26819 million for the Ministry of Economy, Trade and Industry.

- JPY 123851 million for the Ministry of Health, Labour and Welfare.

- JPY 56052 million for the Ministry of Education, Culture, Sports, Science and Technology.

- JPY 23323 million for the Ministry of Agriculture, Forestry and Fisheries.

- JPY 3961 million for the Ministry of Environment.

The total 2001 government budget related to biotechnology is thus estimated to be about JPY 234000 million. This is approximately USD 1500 million PPP adjusted (source: www.jba.or.jp). Note that this figure covers a much broader range of programmes than those presented in the summary of government $\mathrm{R} \& \mathrm{D}$ funding in Table 1 in the international section.

\section{Brief policy overview}

In July 2002, the Japanese government created a biotechnology strategy council to reflect the importance that the government places on biotechnology. The prime minister chairs this council. The b-Japan Plan aims to create a cutting-edge bio-society and bio-based economy by 2010. Approximately half of total public biotechnology funding comes from the Ministry of Health, Labour and Welfare, reflecting the significance of pharmaceuticals in biotechnology funding.

Life science is one of the top priority areas in the science and technology policy areas in Japan. The two main strategic issues in life sciences are in medicine and the production of food and materials. Medicine investment aims to develop innovative technologies for preventative diagnosis and medical treatments, e.g. tailor-made medical treatments for individuals. Investment in the production of materials and food aims to accelerate practical use of knowledge in life sciences to environmentally conscious manufacturing and production of food.

In particular, the Science and Technology Basic Plan for 2001 to 2005 specifies that Japan will focus on the following areas:

- Proteomics, elucidating the three-dimensional structure of proteins and drug-reacting genes, and genome science to develop new medicines, tailor-made medicine and functional food based on such technology. 
- Cellular biology so as to achieve advances in organ transplantation and regenerative medicine.

- Clinical medicine and medical technology, so as to foster practical medical uses of R\&D results.

- Food S\&T for biotechnology that contributes to food security and promotes a healthy diet, as well as sustainable food production.

- Brain science, so as to elucidate brain functions, to control cerebral development disorder and ageing, to overcome neurotic diseases and to develop information-processing and communications systems by applying principles that underlie functioning of the brain.

- Bioinformatics, supporting the above-mentioned technological revolution, in order to analyse a tremendous amount of gene-related data by utilising continually evolving information/ communications technologies.

Figure 37. Biotechnology venture capital investment

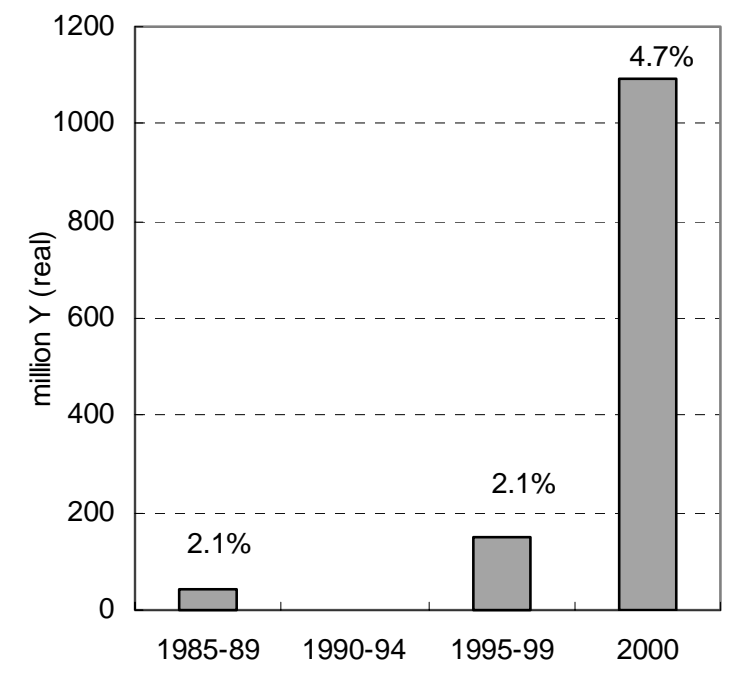

Source: Trends in Japan's Industrial R\&D Activities - Principal Indicators and Survey Data, November 2002, METI et al.

\section{Sources}

Japanese Bioindustry Association Web site www.jba.or.jp as at January 2003.

Major Policies Related to Priority Areas in S\&T Budget (Request) in FY 2001 (in Japanese only), Council for Science and Technology Policy, the Cabinet Office,

http://www8.cao.go.jp/cstp/siryo/haihu12/haihu-si12.html

Science and Technology Basic Plan (2001-2005), March 2001, Government of Japan. Downloaded from the Internet at www.cao.go.jp

Trends in Japan's Industrial R\&D Activities - Principal Indicators and Survey Data, METI et al., November 2002. 


\section{Korea}

\section{Enterprises}

Medicine is an important field for Korean firms involved in biotechnology. A list of companies provided by the Biotechnology Association of Korea (BAK), the Bio Venture Association and Green Cross Inc was used to survey biotechnology firms. Information from this survey was also compared with data from the Manufacturing Industry Survey. 816 biotechnology firms were surveyed; $44 \%$ were engaged in biomedicine or biochemistry.

In terms of the products from the biotechnology firms surveyed, $48 \%$ were attributed to biomedicine. In 2001, biotechnology production from these firms totalled USD 1081 million. Biotechnology production data for 2002 showed a 3.6\% growth. The contribution that biotechnology products make to the national economy has been steadily increasing in recent years. In 1992 the biotechnology industry contributed just $0.03 \%$ of GDP. In 2001, this figure was already up to $0.25 \%$ and it is expected to increase to around $3 \%$ of GDP in 2020 (Choi, 2003).

Figure 38. Distribution of biotechnology firms by industry, 2001

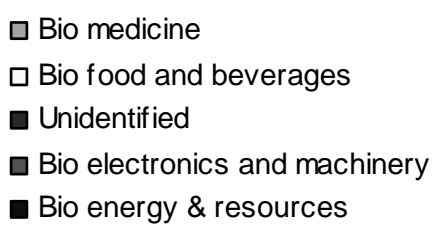

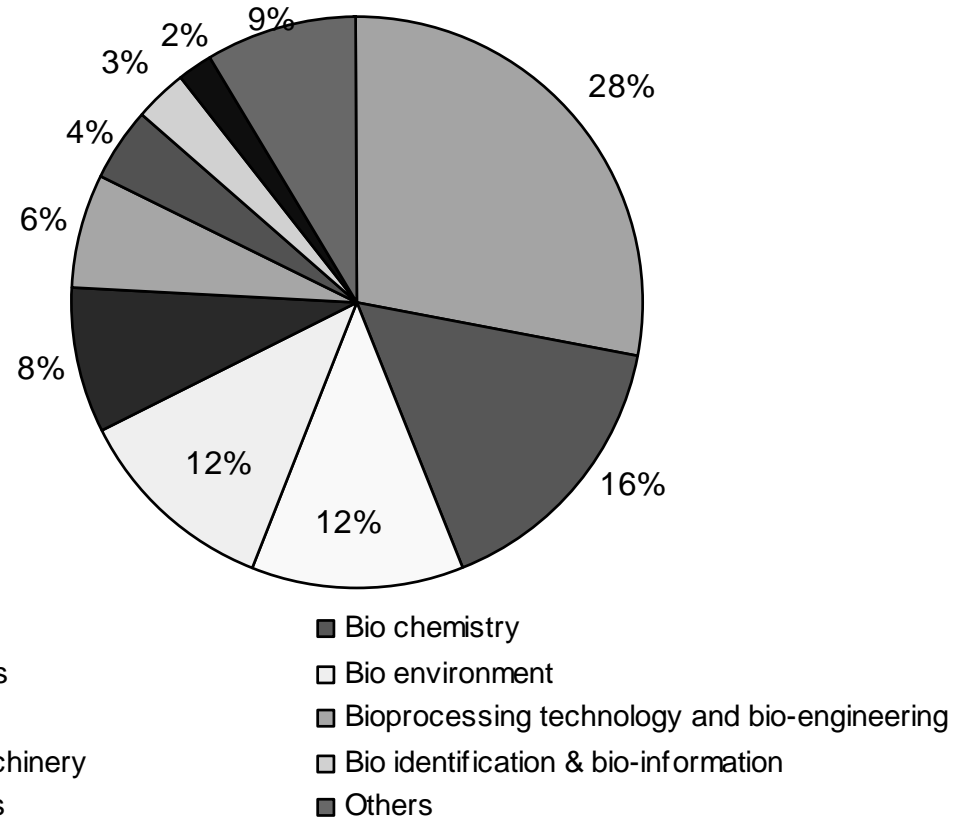

\section{Personnel}

The majority of employees (70\%) in the biotechnology industry have a tertiary qualification. A tertiary qualification is less important for employees involved in production than those in research. In biotechnology research $70 \%$ of employees have at least a Masters degree. Employment in both research and production increased from 2000 to 2001 with increases of $47 \%$ and $32 \%$ respectively. Biotechnology research continues to employ significantly more people than biotechnology production.

Approximately 55\% of all specialised biotechnology employment is found in universities. This ratio has remained fairly steady from 1997 to 2000 inclusive. The share of specialised biotechnology employment attributed to research centres has declined partially at the expense of specialised biotechnology employment in companies. 
Figure 39. Qualifications of employees in the biotechnology industry, 2001

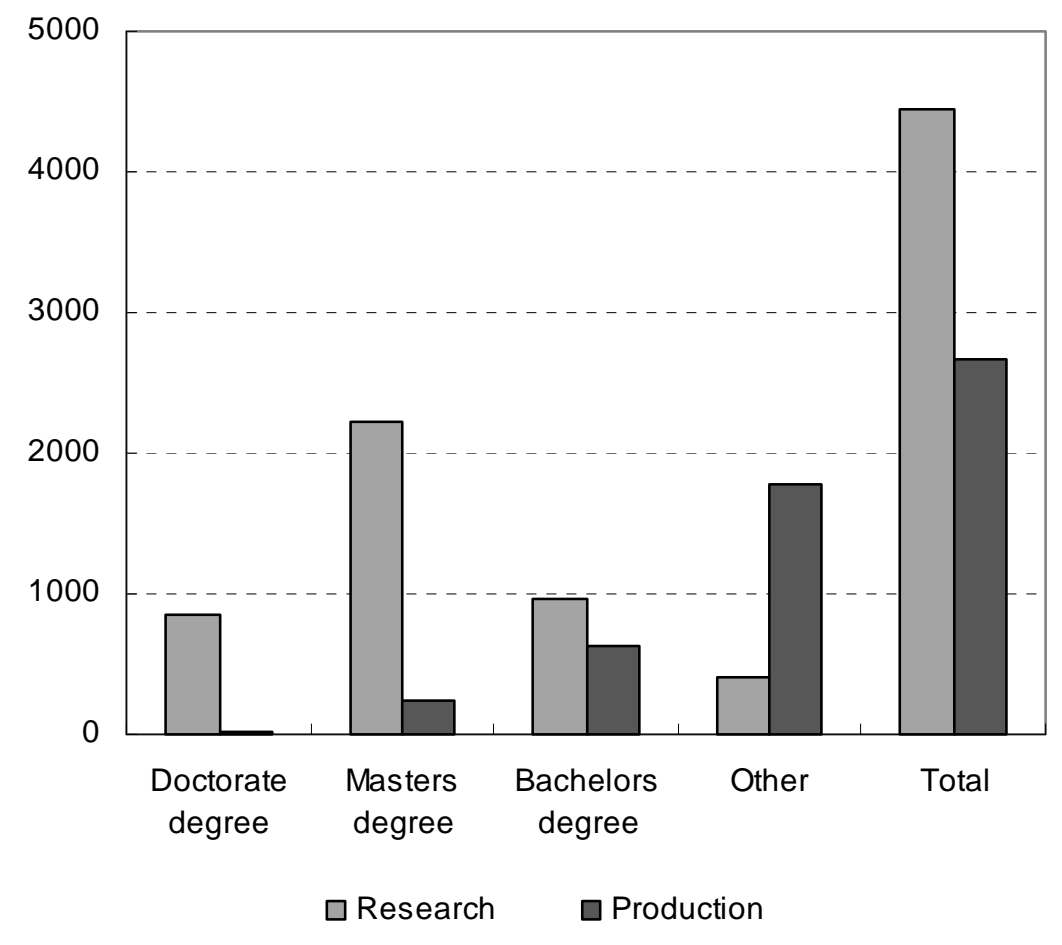

\section{Public funding}

Government investment in biotechnology has increased 48\% from 2001 to 2003 with the 2003 budget for biotechnology being USD 397 million. In 2003, biotechnology accounted for 9\% of the total governmentfunded R\&D budget compared with $7.7 \%$ two years earlier.

\section{Source}

Choi, Youn-Hee (Korean Institute for Industrial Economics and Trade) (2003). Presentation to the $4^{\text {th }}$ Ad Hoc NESTI Meeting on Biotechnology Statistics, OECD, Paris, May 2003. 


\section{Netherlands}

\section{Public funding}

The main agencies responsible for administering Netherlands public biotechnology programmes are the Netherlands Organisation for Scientific Research (NWO) and Senter. Biotechnology programmes mostly deal with genomics or genomics-related areas. Programmes which the NWO administer are:

- Research programme on genomics running from 2001 to 2006 (EUR 13.7 million).

- Research programme on biomolecular informatics running from 2001-2007 (EUR 18.5 million).

- $\quad$ Research programme on structural/functional relation biomolecules running from 1995 to 2003 (approximately EUR 2 million).

- Research programme on social component of genomics research running from 2002 to 2005 (EUR 22.7 million).

The Ministry of Economic Affairs also funds biotechnology programmes. For example, the Ministry of Economic Affairs accounts for $50 \%$ of the funding of the innovation-focused research programme IOP Genomics programme (budget of EUR 20.8 million over 2000 to 2004.) To encourage young biotechnology firms and start-ups, the Ministry of Economic Affairs initiated a special agency in 2000 with a budget of approximately EUR 45 million. The aim of this programme is to achieve 75 new biotechnology companies in five years.

At the end of 2001, the Netherlands government established the Netherlands Genomics Institute with the underlying objective being to "raise the national genomics infrastructure to world-class level within five years". The Netherlands Genomics Institute has a budget of EUR 188.8 million over five years.

\section{Brief policy overview}

The main objective of the NWO genomics programme is to "encourage and co-ordinate qualitatively strong research aimed at the large-scale characterisation of genes and gene products in order to clarify how genes, RNA, proteins and metabolites combine in the functioning of cells, tissues, organs and the entire organism. Research that is aimed at exclusively clarifying the special individual structure or function of a gene or protein is excluded. The generation of genomic sequences is not in itself one of the objectives of the NWO genomics programme unless it makes an essential contribution to solving a functional equation."

The Netherlands Genomics Institute, running from 2002 to 2006, was established as an independent organisation affiliated to the NWO. The Institute was responsible for devising a national strategy. The strategy is characterised by the following areas:

- "The relationship between food and health, including food safety.

- The mechanisms of infectious diseases.

- The origins of multifactorial diseases in which both genetic and environmental factors play a role.

- The functioning of ecosystems, focused on a sustainable, environmentally safe and healthy vegetable and animal products." 
As part of the national strategy, national centres of excellence were established. These centres of excellence support innovation by carrying out unique research on par with the world's leading groups. The Netherlands judged that its status of bioinformatics was poor and therefore designated the development of bioinformatics as a high priority. Bioinformatics was therefore also assigned a major role within the centres of excellence. The national genomics strategy will also deal with societal aspects of genomics research due to increasing levels of public concern with regard to the possible negative implications of new scientific developments, including in the field of genomics. For more information on the strategy and the other areas included in the national strategy, readers are encouraged to consult the Netherlands Genomics Strategy Web site at www.genomics.nl.

\section{Sources}

Kern, S. et al. (January 2003). Effectiveness of Innovation Policies: Biotechnology in the Netherlands (1994-2001).

NWO programme: The Social Component of Genomics Research, NWO Web site, www.nwo.nl

Netherlands Genomics Initiative Web site, www.genomics.nl 


\section{New Zealand}

\section{Enterprises}

Based on survey responses from 419 enterprises, Statistics New Zealand identified 180 enterprises using at least one form of modern biotechnology process (1998-99 biotechnology survey). Food manufacturing, scientific research and local government administration industrial groupings accounted for over half of all areas of biotechnology activity.

\section{Personnel}

Two-thirds of all employees supporting a biotechnology process held a graduate or postgraduate degree. In comparison, a 1993 survey conducted by the NZ biotechnology association found that $84 \%$ of its employed members held a graduate or post-graduate degree.

Figure 40. Percentage distribution of employees supporting biotechnology processes by qualification

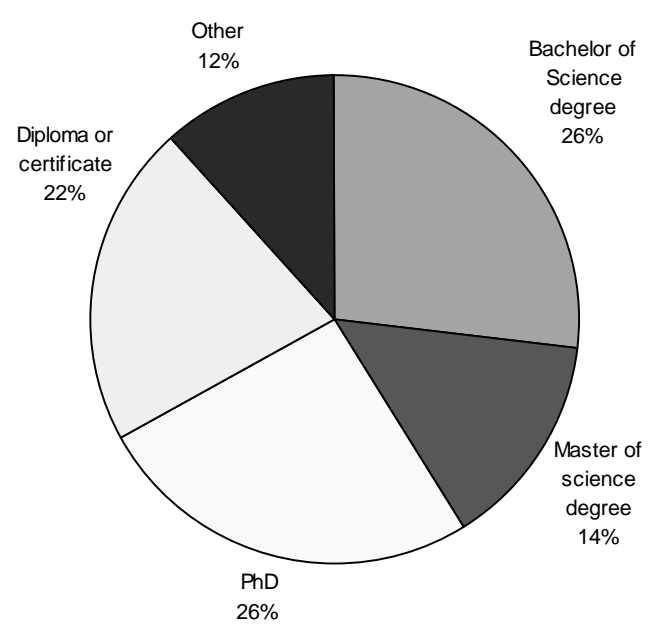

Figure 41. Industrial classification of enterprises using at least one modern biotechnology process

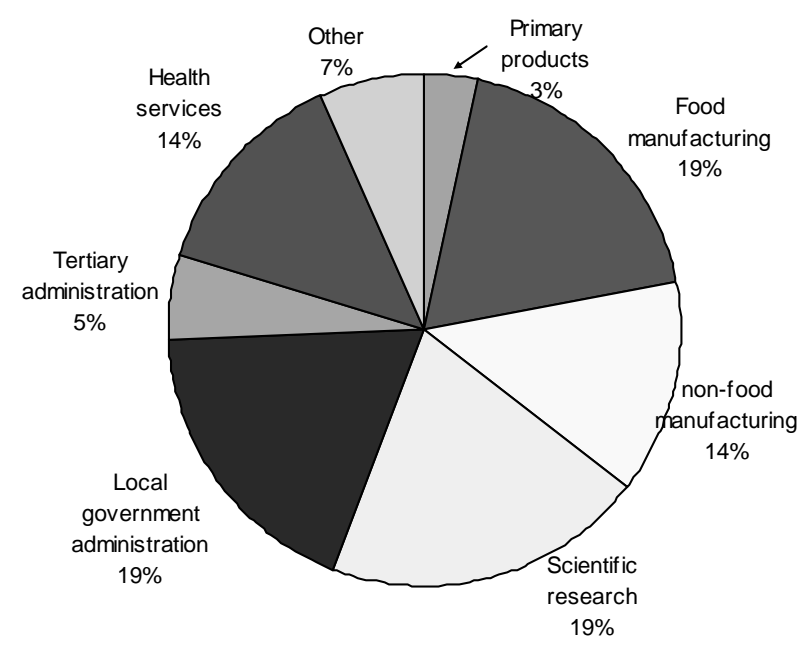

\section{Barriers}

Access to capital and access to personnel were the two barriers of the highest relative importance to the development of modern biotechnology in New Zealand (Statistics New Zealand). Another significant barrier was regulations. These three barriers are all barriers that the Government wants to address. The Government released a public discussion paper in October 2002 to map a way forward for growth in the biotechnology industry.

\section{Funding}

Most of New Zealand's biotechnology knowledge comes from government-funded research institutes and a few private research institutes. Government largely funds this research through grants from a variety of organisations including funding from the Foundation for Research, Science and Technology (FRST), New Economy Research Fund, the Marsden Fund, and the Health Research Council. In 2001, it was estimated that there was about NZD 186 million of government funding on biotechnology-related research. 


\section{Figure 42. Barriers to development of modern biotechnology}

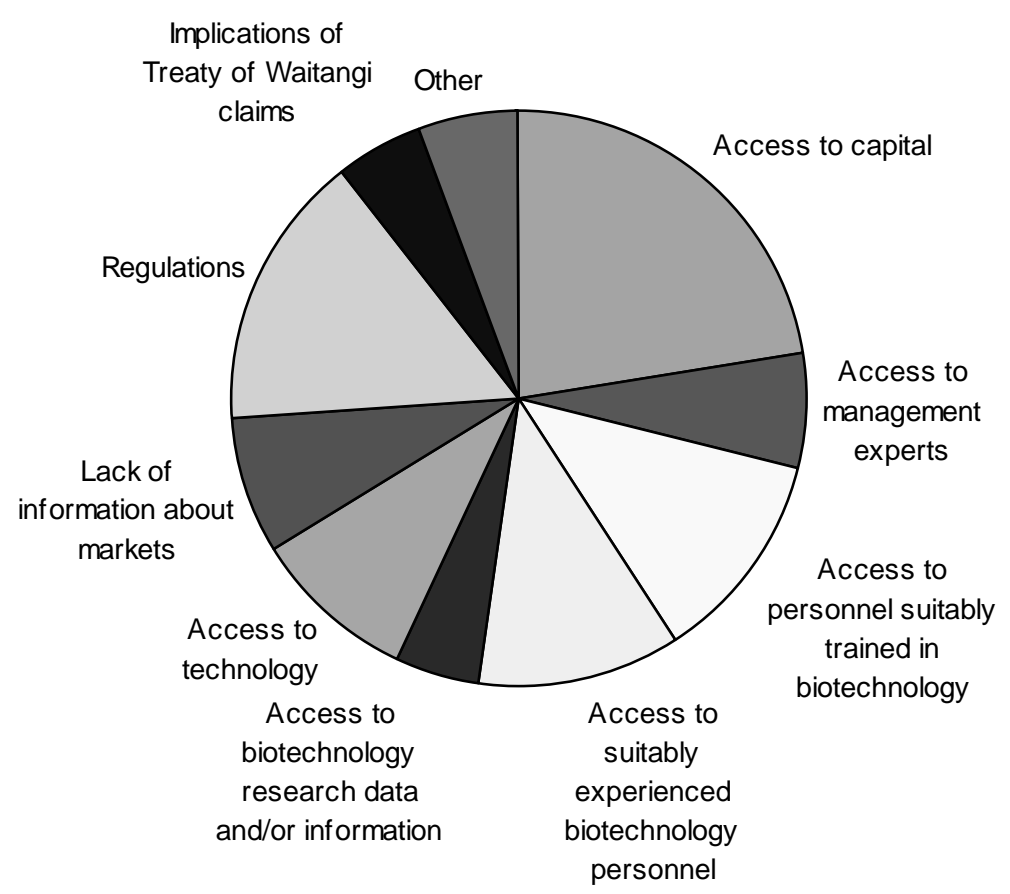

Source: Statistics New Zealand, Modern Biotechnology Activity in New Zealand, April 2001.

New Zealand Biotechnology Strategy (public discussion paper). Ministry of Research, Science and Technology.

\section{Brief policy overview}

Biotechnology is deemed to be an important area by the New Zealand government. More government funding has been directed specifically to biotechnology research in 2002. In October 2002, the Ministry of Research, Science and Technology put out a discussion document asking for public submissions on the government's biotechnology strategy paper. In response to the strategy paper the taskforce convened to investigate the biotechnology sector made recommendations centring around three essential areas:

- The "need to build critical mass" (i.e. increasing employment and biotechnology enterprises).

- Regulatory reforms to "create a competitive environment for growth".

- Establishment of a "robust international network through which to stimulate the flow of international investment".

\section{Sources}

Biotechnology Taskforce (May 2003). Growing the Biotechnology Sector in New Zealand: A Framework for Action, www.biospherenz.com/download/biotech taskforce report.pdf

Ministry of Research, Science and Technology (October 2002). New Zealand Biotechnology Strategy: (public discussion paper), www.morst.govt.nz

Statistics New Zealand (April 2001). Modern Biotechnology Activity in New Zealand. http://statsnz.resultspage.com/search?p=Q\&ts=custom\&w=biotechnology 


\section{Norway}

Funding

In 2001, total public R\&D expenditure on biotechnology R\&D was estimated to be NOK 366 million (about USD 40 million PPP adjusted). Public R\&D expenditure represented about $40 \%$ of total R\&D expenditure. Biotechnology $R \& D$ expenditure is split approximately equally between the higher education, industrial and institute sectors (research institutes and other institutions performing R\&D activities) $)^{3}$. Unfortunately there is no information available as to how this biotechnology R\&D money is spent. In 1999 R\&D expenditure on biotechnology for enterprises was NOK 90 million (USD 9 million PPP adjusted).

\section{Brief policy overview}

A special programme on biotechnology (FUGE - Functional Genomics in Norway) was established in 2001 in order to make Norway competitive internationally. FUGE is supported by the research Council of Norway and represents a co-operative effort between universities, research institutions and the industrial sector. The primary purpose of this project is to ensure that Norway keeps up with international developments in research by strengthening ongoing efforts in functional genomics, integrating functional genomics into the focus of research activities in related fields and building up the infrastructure needed for both these efforts and to increase national expertise in this sphere.

In 2001 the Norwegian government allocated NOK 150 million (approximately USD 16 million PPP adjusted) to the FUGE programme. FUGE has applications in three areas:

- Basic biological research. As well as bringing up the level of basic research disciplines, Norway will work to develop its expertise in areas of strategic importance and also areas where it has special advantages.

- Medical research. FUGE will permit health care services to benefit from the new knowledge and medical products resulting from functional genomics work.

- Marine research. FUGE will help develop the aquaculture industry, optimal utilisation of marine resources and the creation of a biomarine industrial cluster in Norway.

For more information on this programme, see http://www.fuge.no.

\section{Sources}

Norwegian Institute for studies in Research and Higher Education (NIFU).

Research Council of Norway. www.fuge.no.

3. Figures are based on the distribution of $R \& D$ in selected fields from the regular R\&D surveys. Marine biotechnology R\&D is not included in these figures, but a special survey on marine $R \& D$ in the higher education sector (HES) and institute sector makes it possible to identify expenditure. These figures are then added to get an estimate for total expenditure on biotechnology in the HES and the institute sector. When reporting regular R\&D figures internationally, institutes serving enterprises are removed from the Norwegian Institute sector to constitute the government sector and included in industry statistics to constitute the business enterprise sector. 
DSTI/DOC(2003)13

\section{Singapore}

\section{Brief policy overview}

The Singapore government is actively promoting biotechnology and encouraging companies to establish themselves in Singapore. In particular biomedical sciences are a key component for the Singapore government as it would like Singapore to be a world class hub for biomedical sciences. Consequently the BioMedical Research Council (BMRC) was established in October 2000.

The BMRC "oversees and coordinates public sector biomedical research and development activities in Singapore." Their Web site states that their objectives are:

- To support, sustain and stimulate excellent research directed at maintaining and improving human health.

- To train people in high quality skills to meet Singapore's needs of health, quality of life and global economic competitiveness.

- To promote societal awareness of biomedical research.

Consequently the BMRC supports research to develop core capabilities in the following areas of biotechnology: genomics, molecular biology, bioinformatics, bioengineering and bioprocessing in support of the biomedical focus.

\section{Sources}

Agency for Science, Technology and Research (A*STAR) Web site: www.a-star.edu.sg 


\section{Slovak Republic}

\section{Brief policy overview}

The Slovak Republic is most interested in using biotechnology in the food sector. In 1997-98 the government was interested in investigating the introduction of modern biotechnology in agriculture. From 2002 to 2005, EUR 4.7 million, of which EUR 2.8 million is from the government and EUR 1.9 million co-financed by performers, has been allocated to develop progressive technologies. Additionally, from 2001 to 2003, the Slovak government grant agency, VEGA, has allocated about 11000 EUR for some 66 biotechnology-related projects.

\section{Sources}

Private correspondence 


\section{Spain}

\section{Funding}

EUROSTAT's NewCRONOS shows that Spain's government budgetary allocations or outlays on biotechnology R\&D in 1999 amounted to EUR 106.75 million. No more recent figures are available.

According to the Ministry of Science and Technology Web site the government allocated EUR 54 million to the genomics and proteomics programme. This programme is supposed to run from 2001 to 2003 and has a total budget of EUR 154 million (information dated 4 December 2001).

\section{Brief policy overview}

In the national plan for 2000-2003, biomedicine and biotechnology are two high priority areas. The areas of biotechnology that Spain is especially interested in are genomics and proteomics as well as transgenic animals. Key applications of biotechnology are the food and information society areas. Spain intends to develop genomics and proteomics by creating units to further develop knowledge of DNA sequencing, bioinformatics and proteomic knowledge.

The national plan is especially interested in using biomedicine in relation to food, defence, space, environment, tourism, leisure and sport. The strongest application of biomedicine is to the socio sanitary sector. Spain wishes to use biomedicine to deal with human diseases. Transgenic mice will help research into human diseases.

The national plan also mentions the creation of a national biotechnology observatory to oversee biotechnology activity.

\section{Sources}

EUROSTAT, NewCRONOS database.

Plan Nacional de Investigación Científica, Desarrollo e Innovacíon Tecnológica (2000-03), (Vol II), Comisión Interministerial de Ciencia y Tecnología (in Spanish).

Ministerio de Ciencia y Technologia Web site www.mcyt.es (in Spanish). 


\section{Sweden}

\section{Enterprises}

The number of biotechnology firms in Sweden has steadily increased from 1997 to 2001. In a Vinnova and IVA study focusing on small and medium-sized enterprises, Swedish biotechnology companies numbered 183 in 2001. The industrial sector of pharmaceuticals and medicines dominated the Swedish biotechnology industry in the same study. In particular, drug discovery and development was the largest sub-sector when considering the number of companies and employees.

The Vinnova and IVA report states that "the Swedish biotechnology industry is characterised by a high, but slightly decreasing number of new companies and a low, but rising number of disappearing companies." Most of the action is focused on two sectors - the pharmaceuticals and medicine sector and the biotechnology tools and supplies sector. The numbers of biotechnology companies in these two sectors have increased steadily from 1997. In comparison, the other sectors investigated experienced nominal increases over five years.

\section{Revenue}

Turnover for biotechnology companies involved in the pharmaceuticals and medicine sub-sector was the highest amongst small and medium-sized enterprises. Except for agrobiotechnology all sectors increased their turnover. The ratio of turnover per employees also increased. Environmental biotechnology is the sub-sector with the strongest turnover growth, although it has the smallest turnover of the sub-sectors analysed.

\section{Personnel}

The Vinnova and IVA study restricted its analysis to biotechnology firms with up to 500 employees. The study found that in 2001, almost $90 \%$ of companies had fewer than 50 employees. Furthermore, $60 \%$ of biotechnology companies had between one and nine employees inclusive. This pattern has remained largely unchanged from 1997. The biotechnology sector with the most employees was the pharmaceuticals and medicines sub-sector. This pattern is consistent with the growth over the same time period in turnover of biotechnology firms in this sub-sector. Employees in the pharmaceuticals and medicines sub-sector outnumbered the next biggest sector by more than two to one.

\section{Citations}

Citations of scientific publications can be an indicator of the quality of scientific production. The Swedish percentage of the world's total publication volume within biotechnology and applied microbiology increased for most triennial periods from 1987 up to 1999, reaching a share of just over 2\% for 1999-2001.

\section{Sources}

Sandstorm, Anna and Norgren, Lennart (April 2003). Swedish Biotechnology - Scientific Publications, Patenting and Industrial Development, VINNOVA and IVA. 
Figure 43. Number of small and medium-sized biotechnology companies

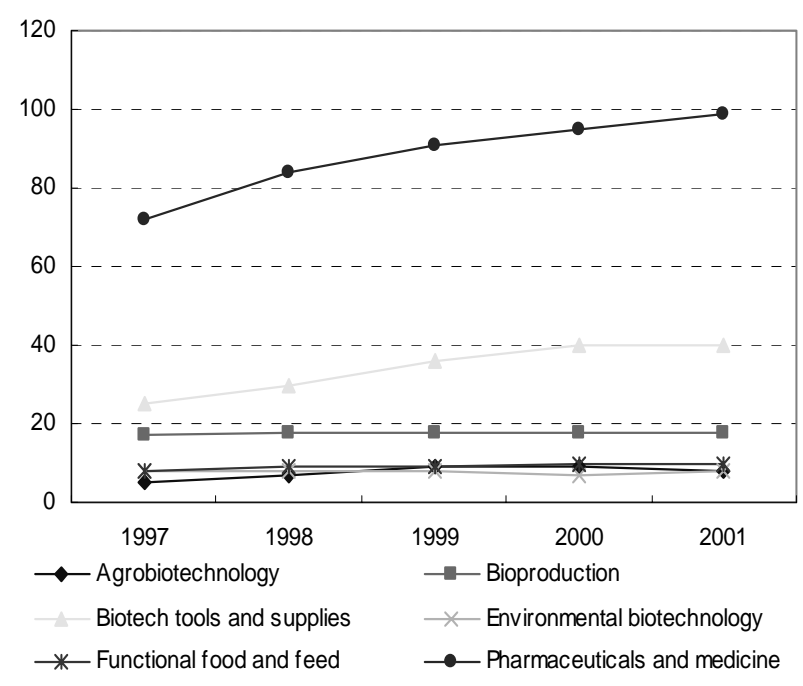

Figure 44. Biotechnology employees in small and medium-sized companies

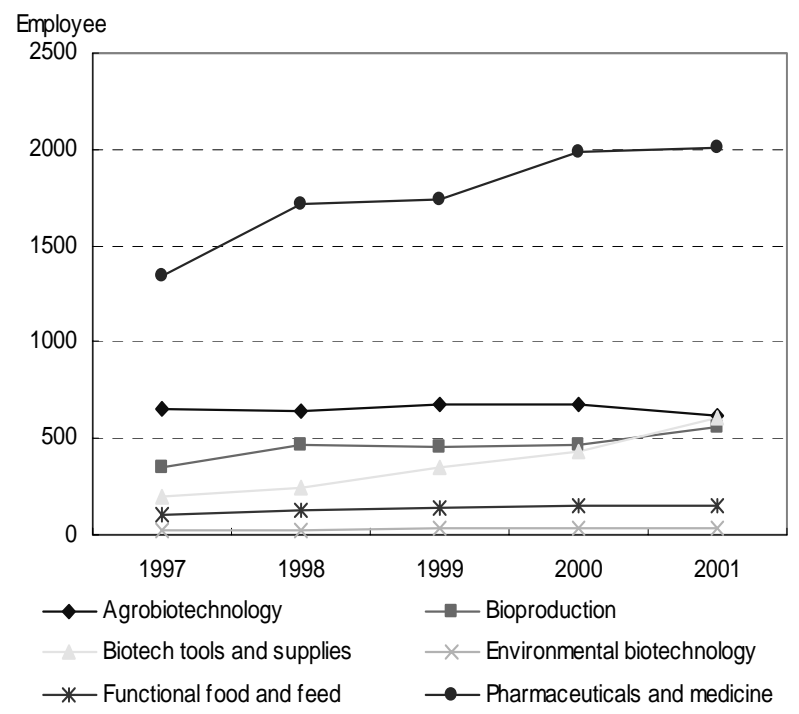

Figure 45. Articles by Swedish public research organisations with largest publication volumes in biotechnology-related sciences by journal categories, 1987-2001

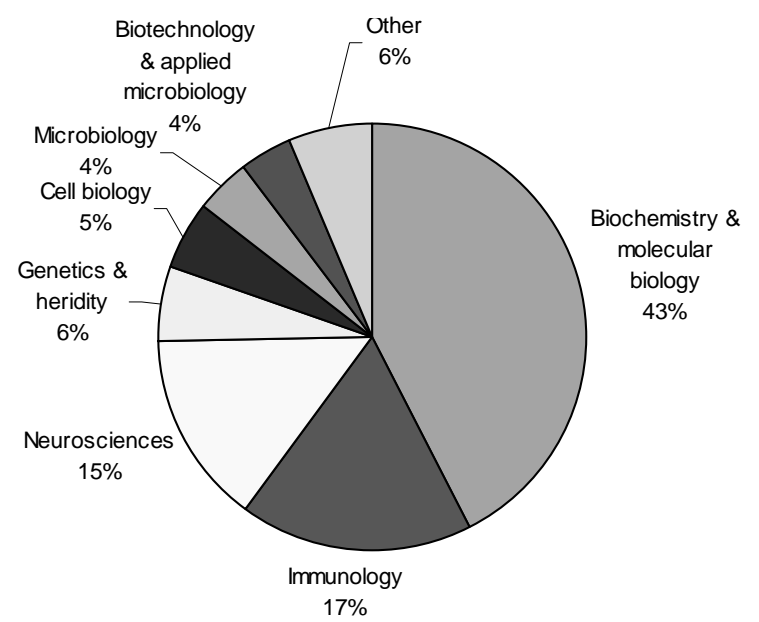

Source: Swedish Biotechnology - Scientific Publications, Patenting and Industrial Development. A. Sandstrom and L. Norgren, 2003. 


\section{Switzerland}

Figures of publicly spent money on research are public and thus available. However, the problem lies in the difficulty to identify specific projects or programmes that could be listed under the term biotechnology and to gather this information. Biotechnology R\&D funding are parts of different R\&D programmes and not separately identifiable. However, in the $2000 \mathrm{R} \& \mathrm{D}$ survey on the private economy, private enterprises spent the largest proportions of their intramural biotechnology $R \& D$ in the research laboratory and pharmacy/chemical branches. These two branches accounted for $76 \%$ of all intramural biotechnology R\&D expenditure. Total intramural biotechnology R\&D for private firms in 2000 amounted to CHF 301.850 million (approximately USD 158 million PPP adjusted). Human health protection and promotion accounted for $71 \%$ of all biotechnology R\&D expenditure. Biotechnology R\&D accounted for about $4 \%$ of total R\&D expenditure.

\section{Source}

Office Fédéral de la statistique (2000), La recherché et le développement dans l'économie privée en Suisse. 


\section{United Kingdom}

\section{Funding}

The Department of Trade and Industry estimates that total United Kingdom support for public sector investment in biotechnology is approximately GBP 1245 million for 2001/2 (USD 1945 million PPP adjusted).

According to the DTI's 2001 Bioguide, four Government agencies are responsible for public biotechnology funding, being the Department of Trade and Industry (DTI), the Department of Health, the Home Office and also Research councils.

For the 2000-01 allocation, the Department of Trade and Industry (DTI) allocated:

- GBP 202 million (approximately USD 310 million PPP adjusted) to the Biotechnology and Biological Sciences Research Council.

- GBP 319 million (approximately USD 490 million PPP adjusted) to the Medical Research Council.

- GBP 181 million (approximately USD 280 million PPP adjusted) to the Natural Environment Research Council.

\section{Brief policy overview}

Biotechnology is a priority for the UK government. The DTI aims to "increase the competitiveness of the UK biotechnology sector by exploiting the science base and influencing all the conditions necessary for the development of the sector". Six key areas of action which the DTI is pressing forward on are:

- "Ensuring that the UK continues to invest in the bio-science research base".

- "Addressing education and training issues".

- "Most importantly, creating a business and fiscal environment in the UK which will attract and retain internationally mobile investment in biotechnology and pharmaceutical R\&D".

- "Influencing policy on, and development of, regulatory and trade issues to ensure an innovative biotechnology industry in the UK can flourish".

- "Getting the conditions right for all stages of development of biotechnology companies including business support services and access to finance".

- "Stimulating companies in a wide range of sectors to use biotechnology in efficient, cleaner processes through technology transfer, demonstrator projects and case studies".

The Department of Health R\&D aims are to "create a knowledge-based health service in which clinical, managerial and policy decisions are based on sound information about research findings and scientific developments." Consequently the Department of Health concentrates its research in three areas:

- Knowledge for evidence-based development of health service policy.

- Personal social service policy.

- Central policy directed at the health and well-being of the population as a whole. 
More information is available on their Web site: www.doh.gov.uk.

The Home Office provides "limited funds for seed corn research into alternatives to animal use and advances in laboratory animal welfare" (DTI, Bioguide).

There are three councils which fund biotechnology-related research:

- The Biotechnology and Biological Sciences Research Council (BBSRC) funds strategic research into non-medical life sciences. The themes of research are agri-food, animal sciences, biomolecular sciences, biochemistry and cell biology, engineering and biological systems, genes and development biology and plant and microbial sciences.

- The Medical Research Council (MRC) supports research relevant to human health care such as work in genetic and protein engineering, monoclonal antibodies, gene therapy and infectious micro-organisms.

- The Natural Environment Research Council (NERC) is involved in research on the "ecology and variation in microbes, plants and animals in the natural environment".

In addition to the above there are three agencies responsible for the strategic issues associated with biotechnology which were created following a 1999 review of the advisory and regulatory framework on biotechnology. The Agriculture and Environment Biotechnology Commission (AEBC), the Human Genetics Commission (HGC) and the Food Standards Agency (FSA). The AEBC was set up in June 2000 to "provide independent, strategic advice on developments in biotechnology and their implications for agriculture and the environment". The HGC advises government on "developments in human genetics and the social and ethical implications". The FSA is an independent food safety watchdog set up in 2000 to "protect the public's health and consumer interests in relation to food". This includes GM food.

Approximately $40 \%$ of UK biotechnology companies are involved in healthcare, with healthcare companies experiencing the biggest increase of the sectors classified in the report commissioned by the UK government. However, the healthcare sector has $60 \%$ of all biotechnology employment.

\section{Sources}

Agriculture and Environment Biotechnology Commission web site, www.aebc.gov.uk

Andersen (March 2002). Results of the 2001 Statistical Survey of the UK Biotechnology Sector.

Department of Trade and Industry (February 2001). Bioguide (2 $2^{\text {nd }}$ edition), www.dti.gov.uk/bioguide.

Food Standards Agency Web site www.foodstandards.gov.uk

Human Genetics Commission Web site www.hgc.gov.uk 


\section{United States}

The following data and accompanying analysis were extracted from A Survey of the Use of Biotechnology in U.S. Industry report by the US Department of Commerce. This report was released in October 2003 and is available at http://www.technology.gov/reports.

This report presents analysis of data collected in the first comprehensive federal survey of U.S. firms' biotechnology-related business activities.

This survey was mailed to 3,189 U.S. companies in August 2002. It represents the culmination of over two years of discussion with biotechnology firms, the Biotechnology Industry Organization (BIO, the largest biotechnology organization in the U.S., representing over one thousand companies), academia, state agencies and governments, and numerous federal agencies.

It should be noted that the results presented in the report do not represent all U.S. firms engaged in biotechnology, and therefore are not national estimates. The data presented underestimate biotechnology activity in U.S. industries. For the complete survey methodology refer to chapter 1 of the aforementioned report.

\section{Enterprises}

In 2001 almost three-quarters of firms (72\%) of the 1,031 firms engaged in biotechnology-related activities indicated that human health $(\mathrm{HH})$ applications are their primary area of biotechnology-related activity. Between $90 \%$ and $98 \%$ of all biotechnology-related financial activity reported by survey respondents was attributable to the 780 companies that selected $\mathrm{HH}$ as a primary or secondary application area.

Between $12 \%$ and $14 \%$ of respondents indicated that their primary or secondary biotechnology activities were related to animal health, agriculture, or aquaculture/marine (AAM) applications, or industrial and agricultural derived-processing.

\section{Economic Performance}

In 2001, the value added of respondents' biotechnology business lines was at least $\$ 33.5$ billion, or $0.33 \%$ of the $\$ 10$ trillion U.S. gross domestic product (GDP) in 2001 (current dollars). The value-added estimate for respondents' entire business activity was $\$ 272.8$ billion, and thus accounted for at least $2.7 \%$ of U.S. GDP in 2001. While net sales of respondents' biotechnology activities were about $9 \%$ of the entire business, the value added of respondents' biotechnology activities was proportionally greater, representing $12 \%$ of the entire business.

\section{Research \& Development Expenditures}

Biotechnology-related R\&D expenditures amounted to $\$ 16.4$ billion in 2001 , about $10 \%$ of all U.S. industry $R \& D$ in that year. $R \& D$ intensity for biotech business lines was $33.4 \%$ in 2001 , compared with $9.5 \%$ for firms' entire businesses and $4.3 \%$ for total U.S. corporate R\&D spending. Also distinct from most other U.S. R\&D companies, respondents generally spent more on research than on later stage development.

\section{Workforce}

Firms reported that more than 66,000 employees could be classified as biotech-related technical workers. Scientists accounted for $55 \%$ of this total. Other occupations included science and clinical laboratory technicians (30\%), engineers (8\%), and $\mathrm{R} \& \mathrm{D}$ focused computer specialists (6\%). Companies also identified a number of employees with biotech-related responsibilities in administration and production, including supervisors, managers, and legal workers. 


\section{Education}

The National Science Foundation reported that the number of biotechnology research doctorates awarded has fluctuated over the period 1993 to 2001 averaging about 11 doctorate awards per year. In 2001 nine doctorates were awarded. In comparison, annual biometrics/biostatistics doctorates awarded averaged about 79 over the same period.

\section{Crops}

According to the U.S. government, 88 million acres of bio-engineered crops were planted in the United States. In 2002, approximately $75 \%$ of all soybean plantings were of a biotechnology variety. This has increased from just over $50 \%$ in 2000 . Corn, in comparison is still predominantly a crop which is not planted as a biotechnology variety. Only a third of all corn planted in 2002 was of a biotechnology variety, a percentage which has increased marginally from the percentage in 2000.

\section{Venture capital}

Biotechnology venture capital disbursements in the United States amounted to $2.7 \%$ of total disbursements in 2000. This is down from a high of $11 \%$ in 1992. Since 1992, biotechnology venture capital disbursement shares have been steadily decreasing over time. (NSF, Appendix table 6-19)

\section{Public perceptions}

The general public has different levels of support for biotechnology depending on the particular branch. Of the people who expressed an opinion, $90 \%$ of people surveyed support genetic testing. In comparison the level of support for animal cloning is equal to the level of opposition. In all three areas of biotechnology, the proportion of people who are neutral is small, indicating that biotechnology is an area where the US public have clearly formed opinions.

\section{Funding}

Unfortunately there are no recent official figures on public biotechnology funding. There has been no attempt to gather biotechnology funding data across the various government departments that engage in biotechnology research activities.

\section{Sources}

US Department of Commerce, A Survey of the Use of Biotechnology in U.S. Industry, October 2003. http://www.technology.gov/reports

National Science Foundation, Science and Engineering Indicators 2002, appendix 7, 2002.

National Science Foundation, Science and Engineering Doctorate Awards, 2001, http://www.nsf.gov/sbe/srs/nsf03300/pdfstart.htm

US Department of State Web site, http://usinfo.state.gov/topical/global/biotech/03011701.htm (January 2003).

US Agricultural Statistics Board, NASS, USDA Web site: www.usda.gov/nass 
Figure 46. Biotechnology activities identified by responding companies

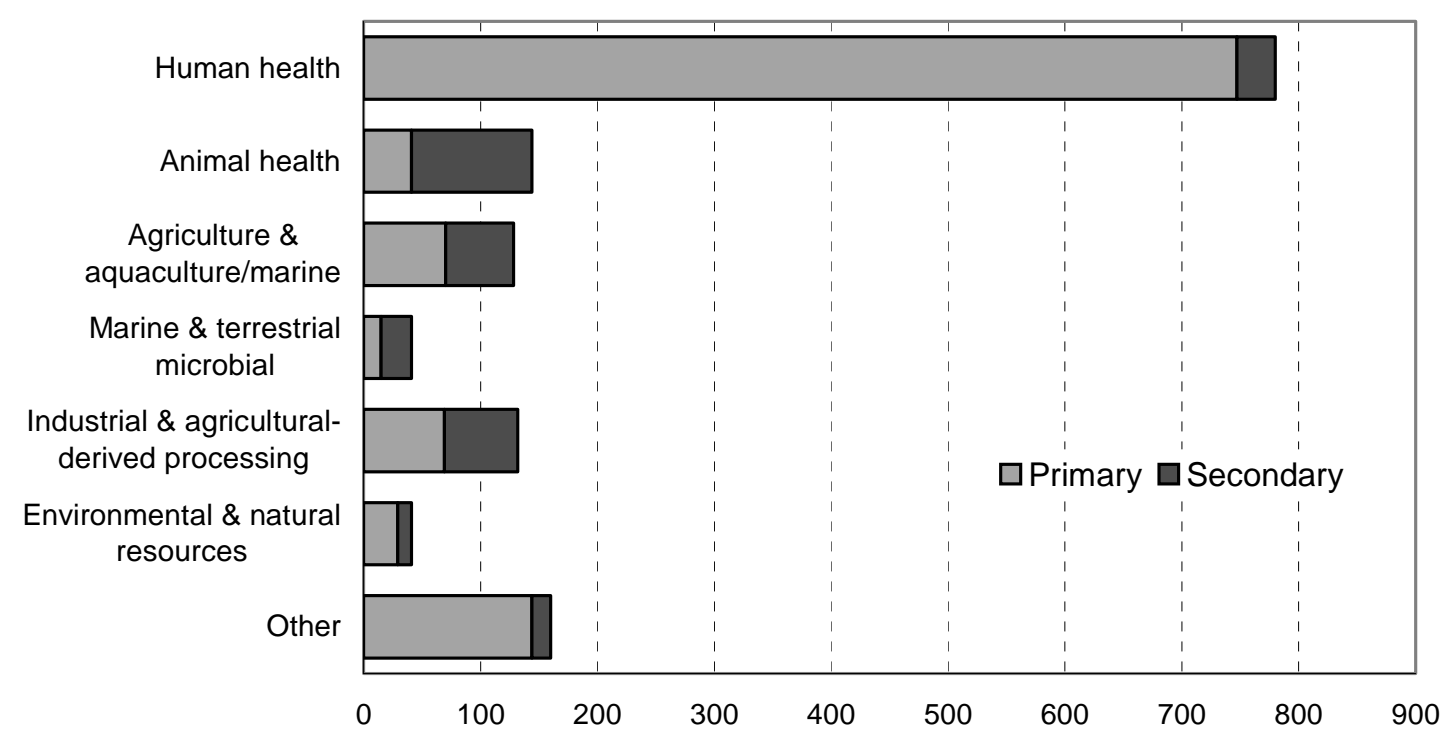

Table 7. Biotechnology activities identified by responding companies, 2001

\begin{tabular}{|l|rrrrrrr|}
\hline \multicolumn{2}{|c}{} & $\begin{array}{c}\text { Human } \\
\text { health }\end{array}$ & $\begin{array}{c}\text { Animal } \\
\text { health }\end{array}$ & $\begin{array}{c}\text { Agriculture \& } \\
\text { aquaculture/marine }\end{array}$ & $\begin{array}{c}\text { Marine \& } \\
\text { terrestrial } \\
\text { microbial }\end{array}$ & $\begin{array}{c}\text { Industrial \& } \\
\text { agricultural- } \\
\text { derived } \\
\text { processing }\end{array}$ & $\begin{array}{c}\text { Environ- } \\
\text { mental \& } \\
\text { natural } \\
\text { resources }\end{array}$ \\
\hline Primary & 747 & 41 & 70 & 15 & 69 & 29 & 144 \\
Secondary & 33 & 103 & 58 & 26 & 63 & 12 & 16 \\
\hline
\end{tabular}

Source: US Department of Commerce, A Survey of the Use of Biotechnology in U.S. Industry, October 2003. http://www.technology.gov/reports

Table 8. Financial and patents overview for $\mathbf{8 8 4}$ survey firms reporting both total and biotech-related R\&D, 2001 (\$ thousands)

\begin{tabular}{|c|c|c|c|c|}
\hline \multirow[b]{3}{*}{$\begin{array}{c}\text { Firm size } \\
\text { category by } \\
\text { number of } \\
\text { employees }\end{array}$} & \multirow[b]{3}{*}{$\begin{array}{l}\text { Number of } \\
\text { companies }\end{array}$} & \multicolumn{3}{|c|}{ Aggregate totals } \\
\hline & & \multirow[b]{2}{*}{$\begin{array}{l}\text { Total non-biotech } \\
\text { and biotech } \\
\text { activity R\&D } \\
\text { investment }\end{array}$} & \multicolumn{2}{|c|}{ Biotech activity only } \\
\hline & & & R\&D investment & $\begin{array}{l}\text { U.S. biotech } \\
\text { patents held }\end{array}$ \\
\hline$>15,000$ & 18 & $15,353,687$ & $3,478,368$ & 2,432 \\
\hline $2,501-15,000$ & 29 & $10,097,255$ & $3,735,319$ & 4,285 \\
\hline $501-2,500$ & 49 & $4,704,300$ & $3,563,309$ & 5,968 \\
\hline $51-500$ & 283 & $5,025,119$ & $4,612,391$ & 7,675 \\
\hline $11-50$ & 299 & 904,083 & 888,490 & 2,431 \\
\hline $1-10$ & 206 & 160,243 & 163,329 & 590 \\
\hline Total & 884 & $36,244,688$ & $16,441,206$ & 23,381 \\
\hline
\end{tabular}

Source: US Department of Commerce, A Survey of the Use of Biotechnology in U.S. Industry, October 2003. http://www.technology.gov/reports 
Figure 47. Biotechnology varieties planted, 20002002

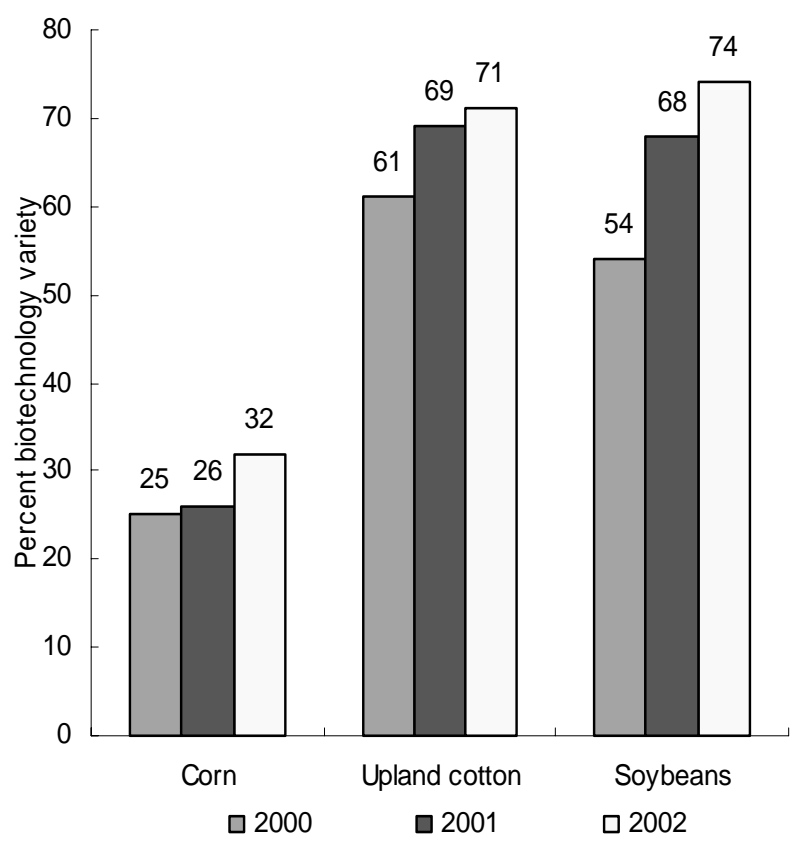

Figure 48. Biotechnology venture capital dispersements

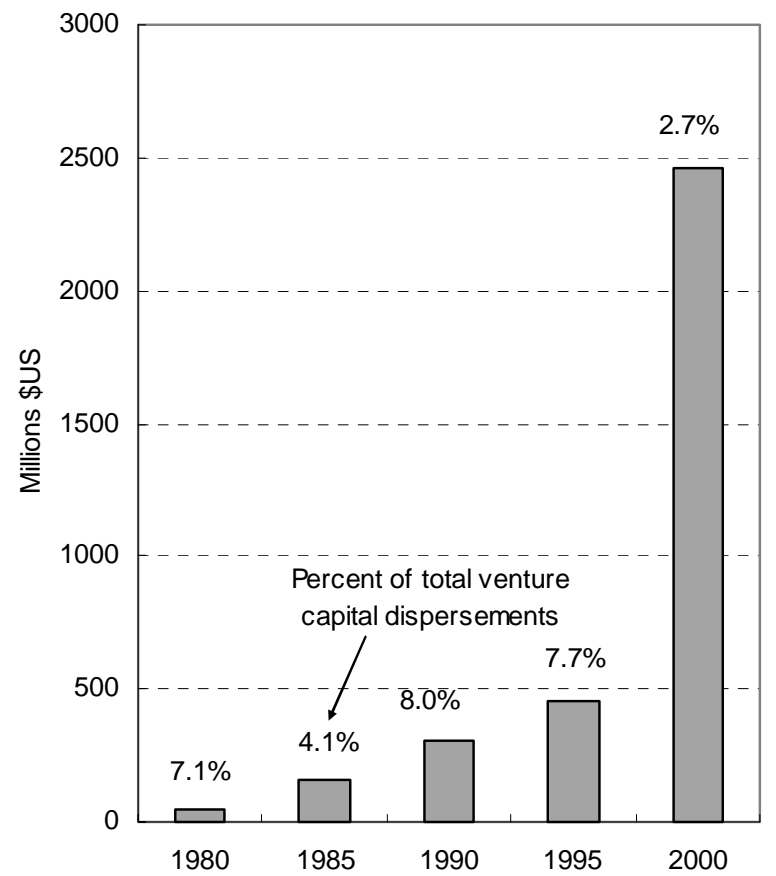

Figure 49. Public assessment of selected biotechnology applications 2001

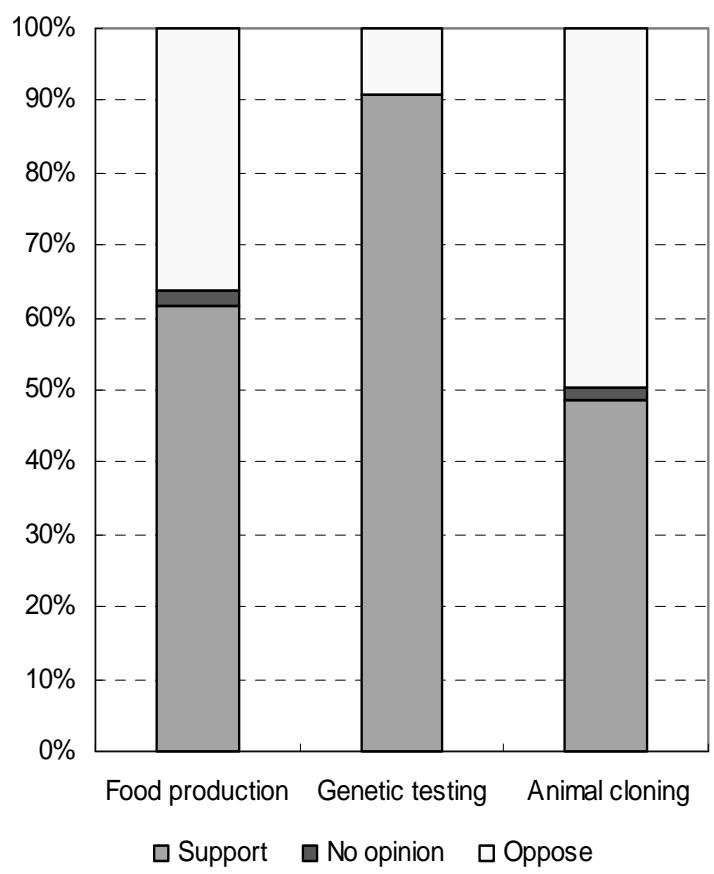

US agricultural statistics Board, NASS, USDA website: www.usda.gov/nass downloaded March 2003 NSF, Science and Engineering Indicators 2002, appendix 7, 2002. 


\section{European Union}

\section{Funding}

The European Union (EU) commenced its $6^{\text {th }}$ framework programme in 2003. From 1 January 2003 until the end of 2006, a total budget of EUR 2255 million has been allocated to life sciences, genomics and biotechnology for health.

\section{Brief policy overview}

Biotechnology is identified as one of the thematic priority areas for the European Union. In particular the $6^{\text {th }}$ framework programme states an interest in advanced genomics and its application for health as well as combating major diseases. Under advanced genomics and its application for health the EU wants to undertake work on fundamental knowledge and basic tools for functional genomics in all organisms. To combat diseases, the EU is adopting an application-orientated approach to medical genomics knowledge and technologies including the use of animal and plant genomics where relevant with respect to:

- Combating diabetes, diseases of the nervous system, cardiovascular diseases and rare diseases.

- Combating resistance to antibiotics and other drugs.

- Studying human development.

For a fuller description of the EU's biotechnology interest in the $6^{\text {th }}$ framework programme, please consult the website: http://europa.eu.int/comm/research/fp6/index_en.html 


\section{TOWARDS THE FUTURE}

This working paper is a collection of statistics and information available at present. It is by no means complete or exhaustive, but rather a reflection of work in progress. Biotechnology statistics have advanced significantly from 2000 until the present resulting in a statistical definition, a model question for R\&D surveys and a model use and development survey.

To improve the comparability and scope of data available, the OECD intends to collect all the developments to date in a "framework" paper. This statistical framework will cover:

- The set of statistical definitions.

- A list of policy issues associated with biotechnology where users need indicators and statistics to analyse and create a factual foundation from which an informed policy discussion can occur.

- A set of indicators to address those issues.

- A set of guidelines for the compilation of those indicators, including the development of model questions and surveys.

- A set of classifications that might be useful for the definition and compilation of statistical indicators.

- A set of links to other manuals.

The OECD Secretariat will also continue to refine the statistical definition when necessary. It is hoped that as more countries start collecting biotechnology statistics using the OECD definition and through the model survey and questions, that eventually biotechnology statistics will improve in international comparability. Eventually the OECD Secretariat would like to explore the benefits that biotechnology offers its member countries, starting initially with the economic benefits as they are easier to measure. 